\title{
Revision of Ryssopterys and transfer to Stigmaphyllon (Malpighiaceae)
}

\author{
C. Anderson ${ }^{1}$
}

Key words

androdioecy

Australia

dioecy

Indonesia

Malpighiaceae

New Caledonia

New Guinea

Ryssopterys

Stigmaphyllon
Abstract Molecular evidence shows the Old World genus Ryssopterys (Malpighiaceae) nested within the New World genus Stigmaphyllon; therefore, Ryssopterys is here transferred to Stigmaphyllon as subg. Ryssopterys. The subgenera share most vegetative and fruit characters. Subgenus Stigmaphyllon comprises 92 species characterized by hermaphrodite, bilaterally symmetrical flowers. Subgenus Ryssopterys includes 21 species that appear androdioecious but are probably functionally dioecious; the flowers are either hermaphrodite but likely functionally female, owing to inaperturate pollen, or male with a rudimentary gynoecium. All species have radially symmetrical flowers in which all parts of each floral whorl are equal; they lack calyx glands as well as the stylar folioles common in subg. Stigmaphyllon, for which the genus is named. The range of subg. Ryssopterys encompasses Indonesia (except Borneo and Sumatra), New Guinea, Queensland (Australia), New Caledonia, Vanuatu, the Solomon Islands, Micronesia, Palau, and the Philippines; S. timoriense has also been recorded from Taiwan and the Ryukyu Islands. An overview of the two subgenera is given. For subg. Ryssopterys summaries of the taxonomic history and morphology, as well as descriptions, a subgeneric key and regional keys, distribution maps, and illustrations of the novelties are provided. Twelve new combinations are proposed: Stigmaphyllon subg. Ryssopterys, S. abutilifolium, S. albidum, S. angustifolium, S. australiense, S. dealbatum, S. discolor, S. grandifolium, S. gymnopodum, S. intermedium, S. taomense, S. timoriense. Ten new species are described: S. brassii, S. mackeeanum, S. mariae, S. mcphersonii, S. merrillii, S. micranthum, S. papuanum, S. pullenii, S. solomonense, S. sundaicum.

Published on 12 April 2011

\section{INTRODUCTION}

The family Malpighiaceae is of New World origin, and the Old World representatives are derived from New World ancestors (Cameron et al. 2001, Davis et al. 2001). Recent investigations of the generic phylogeny of the Malpighiaceae by Davis \& W.R.Anderson (2010) confirmed that the Old World genus Ryssopterys is nested within the New World genus StigmaphylIon; all other Old World genera are sister to a New World clade. Support values for the Stigmaphyllon clade and for the Ryssopterys clade are $100 \%$. This result is not surprising, if one considers that Stigmaphyllon and Ryssopterys differ only in floral morphology and geographical distribution. Because retaining Ryssopterys as a separate genus would render Stigmaphyllon paraphyletic, the transfer of Ryssopterys to Stigmaphyllon as subg. Ryssopterys is proposed. The diverse subg. Stigmaphyllon includes 92 species (C. Anderson 1997, 2000,2009 ) and likely will be divided into additional subgenera as the species relationships become known.

Transfer of Ryssopterys to Stigmaphyllon prompted a review of the Old World species, which revealed a surprising number of novelties. As noted under Taxonomic History, the encompassing view presented in Flora Malesiana (Jacobs 1955), which assigned all collections from the region covered to either $R$. tiliifolia or $R$. timoriensis, obscured the true diversity. Subgenus Ryssopterys now comprises 21 species, of which ten are here newly described. This revision, based entirely on herbarium material (see Acknowledgements), must be viewed as a preliminary assessment. Others may find some of my circumscriptions also too broadly drawn; field work will define the species ranges, which now reflect mostly limited collecting

\footnotetext{
1 University of Michigan Herbarium, 3600 Varsity Drive, Ann Arbor, MI 48108 USA; e-mail: chra@umich.edu.
}

activity. Future workers may uncover the origins and phylogeny of subg. Ryssopterys, the developmental changes in the shift in floral architecture, and the role of dioecy in population structure.

\section{TAXONOMIC HISTORY}

Genera in Malpighiaceae were very broadly interpreted until Adrien de Jussieu began his monographic studies of the family and proposed clearly defined generic limits. The first species now assigned to subg. Ryssopterys were described in Banisteria L. (Ventenat 1808, De Candolle 1824), Heteropterys Kunth (Blume 1825), and Hiraea Jacq. (Blume 1825). Jussieu (1838) erected the genus Ryssopterys with one species, $R$. timoriensis, based on Banisteria timoriensis DC.; he cited Blume's names Hiraea ovata and $H$. obscura in synonymy. In his Malpighaceaerum synopsis (Jussieu 1840), he added one new species, $R$. abutilifolia, and proposed one new combination, $R$. tiliifolia, based on Ventenat's Banisteria tiliifolia, with Blume's Heteropterys albida cited in synonymy.

Jussieu's monograph of the Malpighiaceae was published in 1843, and under Ryssopterys he listed six species. To R. abutilifolia, R. tiliifolia (now excluding Heteropterys albida), and $R$. timoriensis, he added three new species from the Philippines. Ryssopterys cumingiana and $R$. dealbata are each based on a Cuming collection; for $R$. microstema Jussieu listed, in addition to a Cuming collection, a Blume collection from Java and now cited Heteropterys albida Blume in synonymy, thus creating a superfluous name. During the next sixty years several species were added. Hasskarl (1858) proposed R. chrysantha, and Turczaninow (1863) published $R$. ovata and $R$. rufescens, but both belong to Aspidopterys A.Juss. Hochreutiner (1904) added $R$. intermedia and Gandoger (1913) R. discolor. 
Niedenzu, the second monographer of the Malpighiaceae, published on Old World Malpighiaceae in 1915 and recognized eight species in Ryssopterys: $R$. abutilifolia (including $R$. intermedia as var. intermedia), $R$. dealbata (including $R$. cumingiana), R. microstema, R. tiliifolia, R. timoriensis, and three novelties, $R$. angustifolia, $R$. australiensis, and $R$. austrocaledonica. In his treatment of Ryssopterys for Das Pflanzenreich (1928), Niedenzu also accepted eight species but with some differences; $R$. abutilifolia, $R$. angustifolia, $R$. austrocaledonica, $R$. dealbata, $R$. timoriensis, and $R$. tiliifolia (including $R$. chrysantha) remained unchanged. He was unaware of Baker's (1921) publication of $R$. taomensis, but he accepted $R$. discolor (described from New Caledonia) and listed his $R$. australiensis as a synonym. He expanded $R$. discolor to include all collections from the Philippines with pubescent leaves, except Cuming 1845 , which he listed as $R$. albida; Merrill (1923) had published the combination $R$. albida to replace the superfluous name $R$. microstema.

Except for the addition of $R$. gymnopoda (Guillaumin 1932) and $R$. grandifolia (Guillaumin 1942), Niedenzu's interpretation of the genus remained accepted until the publication of the treatment of the Malpighiaceae for Flora Malesiana (Jacobs 1955). For Ryssopterys Jacobs recognized only two species: $R$. tiliifolia, defined by apiculate anthers and a samara $4-6 \mathrm{~cm}$ long, and $R$. timoriensis ("a very variable species") for all other collections; he reduced $R$. discolor to a variety of $R$. timoriensis. As a result, the name $R$. timoriensis has been indiscriminately applied to collections obtained throughout the range of the genus, and the diversity of Ryssopterys was unrecognized in recent floristic literature.

Stigmaphyllon subg. Ryssopterys is here interpreted to encompass 21 species. Eleven species were previously described (S. abutilifolium, S. albidum, S. angustifolium, $S$. australiense, $S$. dealbatum, S. discolor, S. grandifolium, S. gymnopodum, S. intermedium, $S$. taomense, $S$. timoriense) and ten are novelties (S. brassii, S. mackeeanum, S. mariae, S. mcphersonii, $S$. merrillii, S. micranthum, S. papuanum, S. pullenii, S. solomonense, $S$. sundaicum). Two names merit comment. The basionym Banisteria tiliifolia has to be set aside, because the name Stigmaphyllon tiliifolium is already occupied (S. tiliifolium Nied. = S. dichotomum (L.) Griseb.). The next available name is Heteropterys albida Blume, and the name Stigmaphyllon albidum applies to the species from Java and adjacent islands formerly called $R$. tiliifolia. The Philippine species that Merrill (1923) and others determined as $R$. albida and R. microstema is without a name and is here described as $S$. merrillii.

\section{COMPARISON OF SUBGENUS STIGMAPHYLLON AND SUBGENUS RYSSOPTERYS}

Typically, species of both subgenera are woody vines with elliptical to cordate leaves, often long-petioled, and yellowpetaled flowers grouped in umbels or pseudoracemes that are arranged in dichasially branched inflorescences. Each flower is borne on a pedicel subtended by a pair of bracteoles, which itself is borne on a peduncle subtended by a bract; this unit represents a 1 -flowered cincinnus (Fig. 1a). The gynoecium is composed of a tricarpellate ovary with three free styles; the fruit is a schizocarp that splits into three samaras, each with an elongate dorsal wing and suspended from a carpophore (Fig. $2 \mathrm{k}$ ). Differences in flower structure between subg. StigmaphylIon and subg. Ryssopterys are summarized in Fig. 1b-g.

Species of subg. Stigmaphyllon, like the majority of New World Malpighiaceae, have hermaphrodite flowers that are pollinated by oil bees; the bilaterally symmetrical architecture of the flower reflects this pollination syndrome. The calyx is composed of five sepals; each lateral sepal bears a pair of large oil glands, but the anterior sepal is eglandular (except in S. boliviense C.E.Anderson and S. coloratum Rusby). The corolla consists of four lateral petals and a posterior petal, the 'flag'; all are clawed (Fig. 1e), but the claw of the posterior petal is longer and stouter than that of lateral petals. The bee grasps the claw of the 'flag' petal with its mandibles and reaches between the lateral petals to scrape the oil glands that are borne on each lateral sepal. Most species of subg. Stigmaphyllon have a heteromorphic androecium (Fig. 1f) and styles with apical folioles (Fig. 1g); the anterior style differs from the two equal posterior ones. The stigma is placed at the apex of the style but always on the adaxial angle, never terminally.

In contrast, the flowers of subg. Ryssopterys are radially symmetrical (Fig. 1b); the components of each floral whorl are equal. The sepals are eglandular (very rarely 1 or 2 sepals of a calyx with a rudimentary gland), and the petal claw is rudimentary or absent. The stamens and styles are uniform, and the stigma is terminal (Fig. 1c, d). It is assumed that this architecture reflects the shift in pollination syndrome in the ancestor of subg. Ryssopterys to one in which the reward is pollen, given the absence of oil bees that visit Malpighiaceae in the Old World.

In previous accounts, such as in Flora Malesiana (Jacobs 1955), subg. Ryssopterys was described as androdioecious, because plants bear either perfect or male flowers. A study of the breeding system of subg. Ryssopterys is beyond the scope of this revision; however, true androdioecy is rare in flowering plants (G. Anderson \& Symon 1989). Examination of pollen, stained with aniline blue in lactophenol, shows that the grains of the hermaphrodite flowers are inaperturate, whereas the pollen of male flowers is 6-porate. The same phenomenon was reported by W.R. Anderson (2001) for the Malagassy species Rhynchophora phillipsonii (Malpighiaceae), which also has hermaphrodite and male flowers borne on different plants. Presumably the pollen of hermaphrodite flowers serves only as a reward for the pollinator, and the hermaphrodite flowers are functionally female. Therefore, the species of subg. Ryssopterys are most likely dioecious.

Subgenus Stigmaphyllon occurs from southern Mexico and the Caribbean to northern Argentina, except Chile, in diverse habitats, except the alpine Andes; one species, S. bannisterioides, has become established in coastal western Africa (C. Anderson 1997, 2000, 2009). Subgenus Ryssopterys is found in coastal and other low-elevation sites (to c. $1500 \mathrm{~m}$ ) in Indonesia (except Borneo and Sumatra), the Philippines, New Guinea, Palau, Micronesia, Vanuatu, New Caledonia, and Australia (Queensland); one species, S. timoriense, has been recorded from Taiwan and the Ryukyu Islands (Miyako Island).

\section{MORPHOLOGY OF STIGMAPHYLLON SUBGENUS RYSSOPTERYS}

\section{Habit}

All species of subg. Ryssopterys are woody vines. Label data indicate that they reach to $20 \mathrm{~m}$; however, the reports are few, and the true height achieved by each species is unknown. Stems are densely sericeous when young and glabrescent to glabrous with age.

\section{Leaves}

All species have opposite leaves. The petioles are sericeous or sparsely so, and bear a pair of large glands (to $3 \mathrm{~mm}$ diam) at or near the apex; sometimes the glands are placed partly on the base of the lamina. The laminas vary greatly in shape and in size, even on the same specimen, but are commonly lanceolate or ovate to elliptical or cordate; only S. angustifolium has consistently narrow leaves $(0.3-2.7 \mathrm{~cm}$ wide), which are 

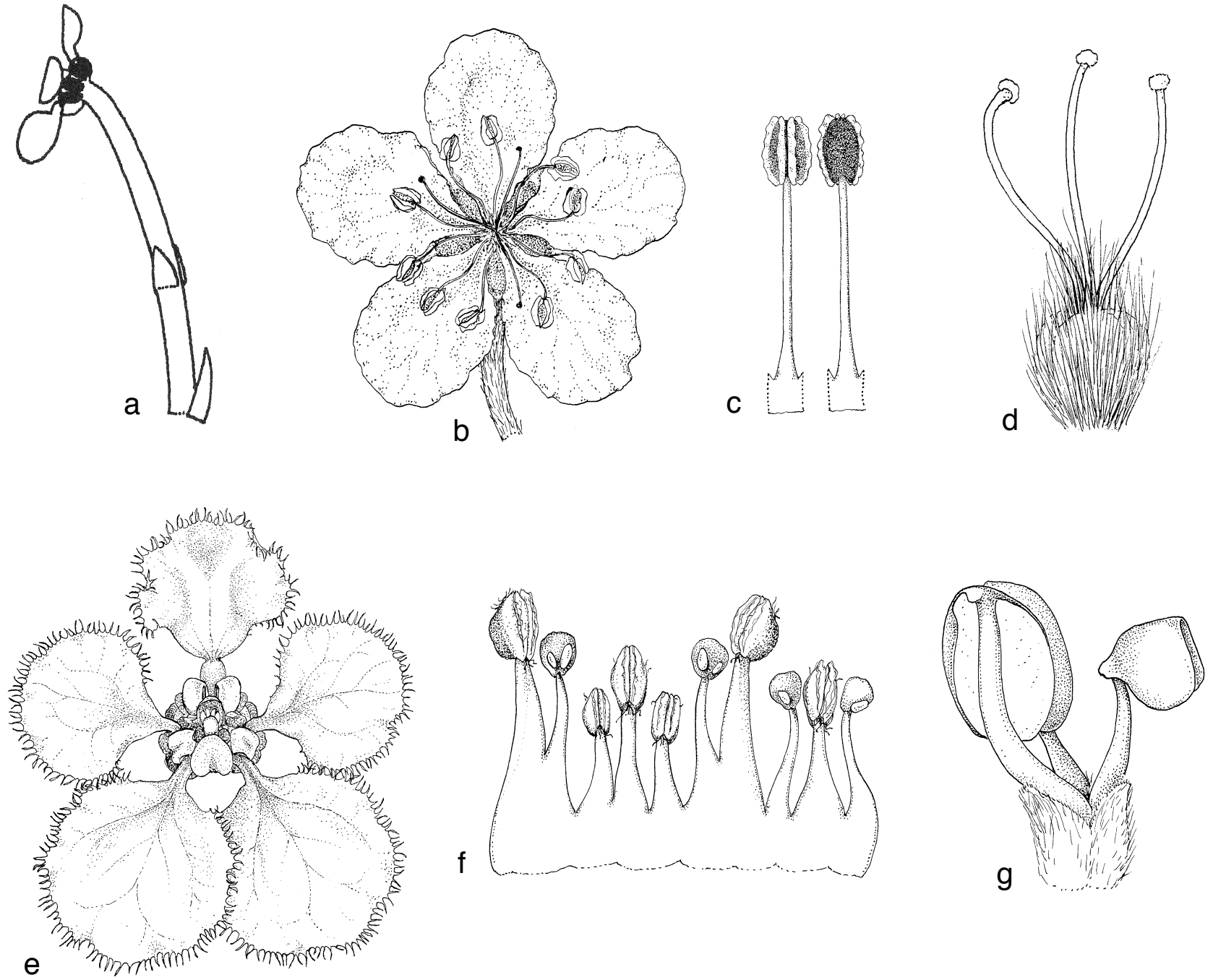

Fig. 1 Flower structure in Stigmaphyllon. a. One-flowered cincinnus: flower borne on a pedicel subtended by a pair of bracteoles; pedicel borne on a peduncle subtended by a bract. - b-d: subg. Ryssopterys. b. Flower of $S$. dealbatum; c. two stamens of $S$. mariae; d. gynoecium of hermaphrodite flower of S. dealbatum. - e-g: subg. Stigmaphyllon. e. Flower of S. sinuatum: posterior petal ('flag') at top; f. androecium of $S$. saxicola: stamen opposing posterior petal second from right; g. gynoecium of $S$. calcaratum: anterior style at right.

most commonly linear to oblong. The base varies from truncate to acute or cordate. The apex is commonly apiculate but may also be emarginate, acuminate, or caudate. In all species the youngest laminas are pubescent on both surfaces, but the adaxial vesture is soon entirely or mostly sloughed off, except in $S$. australiense, where the adaxial vesture may be retained at maturity. The absence or presence (and nature) of abaxial vesture is characteristic of a species. Species with the laminas abaxially glabrous at maturity often retain some scattered hairs on the costa and at the base near the petiole insertion. Abaxial vesture may be variously tomentose or sericeous. In $S$. dealbatum, the abaxial lamina is initially tomentose, but the vesture is shed in patches; even mature leaves may bear tufts of hairs or rarely show large areas of thinned tomentum. In species with abaxially pubescent laminas the vesture of very old leaves may be sparse or even sloughed off, and the species might be mistaken for one with glabrous leaves. The hairs are medifixed and sessile to subsessile, or even show a minute stalk to $0.1 \mathrm{~mm}$ long; the trabecula varies from straight or wavy to crisped or curled. Only the vesture of $S$. merrillii includes pronounced T-shaped hairs, with a stalk to $0.2 \mathrm{~mm}$ long, like those commonly found in subg. Stigmaphyllon. In nearly all species the laminar margin bears some irregularly spaced glands to c. $0.5 \mathrm{~mm}$ diam. Such glands are sometimes absent in S. gymnopodum, S. mackeeanum, S. taomense, all of New Caledonia, and in S. papuanum, of Papua New Guinea. Only the New Caledonia endemic S. angustifolium always lacks marginal leaf glands. Because many collectors take only the terminal flowering or fruiting portion of a plant, the variation in size and shape of leaves and stipules from the older vegetative parts is unknown for most species.

Two types of stipules are found in subg. Ryssopterys, and each is consistent within a species. The more common type (e.g., Fig. $6 \mathrm{~b}, \mathrm{~m}, 9 \mathrm{c})$, which is also characteristic of subg. Stigmaphyllon, is bract-like and triangular, to c. $1.5(-3) \mathrm{mm}$ long. Usually, one bractlike triangular stipule is found on each side of the petiole; occasionally, a smaller second one is found in S. discolor, S. mackeeanum, S. sundaicum, and S. taomense. The stipules of $S$. angustifolium, S. gymnopodum, and S. mcphersonii are rudimentary; they are up to $0.3 \mathrm{~mm}$ long and often hidden by the stem pubescence. The second type of stipule is leaflike (e.g., Fig. $2 d, 5 b$ ) and variously shaped, from linear to elliptical or ovate to orbicular; the largest of such stipules may be divided into a small petiole and lamina to more than $5 \mathrm{~cm}$ long. Leaflike stipules are placed two or three on each side of a petiole and form a row across the node; those nearest the petiole are always larger than the rest. On old stems from which the stipules may have fallen, a discrete small scar next to the petiole indicates the loss of a bractlike, triangular stipule, whereas a row of scars or a continuous scar across the node indicates that leaflike stipules were present. 


\section{Inflorescences}

The flowers are aggregated into umbels or condensed to loose pseudoracemes, and in most species these units are borne in compound inflorescences of a dichasial pattern, as in subg. Stigmaphyllon. Only species of New Caledonia have only solitary umbels, or umbels either solitary or three umbels in a dichasium. The inflorescences are axillary, and the axes are always sericeous, though the vesture may become sparser with age and be eventually sloughed off. The flowers of subg. Ryssopterys are either hermaphrodite (but apparently functionally female) or male, and radially symmetrical.

\section{Perianth}

The five eglandular sepals are oblong to broadly ovate or suborbicular. The abaxial surface is sparsely to densely sericeous or glabrous, and the margin is ciliate. In two collections (Tippett UNPG 825, S. mariae; Weinland 363, S. pullenii) one or two sepals of a calyx bear a rudimentary commissural gland (to 0.3 $\mathrm{mm}$ diam) at the base, which resembles the glands borne at the apex of the petiole but not the oil glands found on sepals of subg. Stigmaphyllon. Such anomalous calyx glands are found in some species of the New World genus Galphimia Cav. (C. Anderson 2007) and some Old World genera, e.g. Acridocarpus Guill. \& Perr. and Triaspis Burch. (W.R. Anderson, pers. comm.), which also lack oil glands on the sepals.

The five petals are orbicular or broadly obovate and cucullate; in most species a tiny claw is present (usually much less than $1.5 \mathrm{~mm}$ long).

\section{Androecium}

The stamens number 10 in most species, but 12-18 in S. discolor, S. mackeeanum, and S. solomonense. The hairlike filaments are basally united in a shallow cup or rim. The anther is composed of a well-developed connective and two thecae opening by a longitudinal slit. The anthers of $S$. albidum terminate in a prominent apiculum in specimens from Java; in collections from Flores, Sumba, and Sumbawa the apiculum may be very short or may be represented merely by an acute apex. A minute apiculum is sometimes found in other species, e.g., in hermaphrodite flowers of S. papuanum (Fig. 6i). Anthers are pubescent in S. abutilifolium, S. dealbatum, and S. timoriense; however, presence of such hairs is apparently variable. In some collections of $S$. dealbatum and $S$. timoriense the anthers bear only a few scattered hairs or are glabrous; also, the hairs may fall off spent anthers. Within species, the stamens and/or anthers may be larger in male flowers than in hermaphrodite flowers, e.g., in S. micranthum and S. papuanum (Fig. 6h, i, s, t). The pollen is spherical and 6-porate (Lowrie 1982) in male flowers but inaperturate in hermaphrodite flowers.

\section{Gynoecium}

The tricarpellate ovary is densely pubescent and bears three free styles, each with a terminal peltate stigma, although in a few species the stigma is slightly slanted; in S. solomonense the stigma extends for a short distance on the inner surface of the style. Most species have slender filiform styles $2.5-4.5 \mathrm{~mm}$ long and c. $0.1 \mathrm{~mm}$ wide; however, four species (S. albidum, S. merrillii, S. micranthum, S. papuanum) are characterized by short stout styles 1-2 mm long and c. $0.2 \mathrm{~mm}$ wide (Fig. 6j, u). In male flowers, the gynoecium is rudimentary. The ovary is reduced to a minute mound of tissue embedded in a tuft of hairs, except in $S$. papuanum, in which the receptacle is glabrous. In most species, the male flowers lack styles, although sometimes the 'ovary' may be extended into a short beak. The male flowers of S. dealbatum, S. pullenii, and S. solomonense have well-developed styles, like those of the hermaphrodite flowers. Styles are also present in the male flowers of $S$. abutilifolium, $S$. discolor, S. mackeeanum, and $S$. taomense, but often in these species only one style is free and the other two are variously united, proximally (e.g., Fig. 4g) or distally, or rarely all three styles are united into one stout structure with a large 3-lobed stigma. The expression of styles in male flowers is apparently quite plastic; occasionally styles or rudimentary styles appear in a male flower of a species that usually lacks them, or deformed styles occur in male flowers of species with usually well-developed styles. In S. mariae, styles in male flowers may be absent, or present and then varying from rudimentary to normal.

\section{Fruit}

The fruit is a schizocarp splitting into three samaras, each suspended by a carpophore from a pyramidal torus (Fig. $2 \mathrm{k}$ ). The nut varies from spheroid to ovoid to narrowly ellipsoid and bears a large dorsal wing. The surface of the nut is sometimes almost smooth but usually prominently ribbed and may also bear lateral winglets and/or spurs. The wall of the locule is thick and woody, unlike in subg. Stigmaphyllon. Embryos were available for only fourteen species. In eleven species, the cotyledons are equal or slightly unequal, and straight or the outer cotyledon slightly bent upward at the tip. In S. albidum, S. intermedium, and $S$. sundaicum the cotyledons are convoluted and folded within each other, giving the embryo a brainlike appearance (Fig. 9k; the folding is more pronounced in S. albidum). In subg. Stigmaphyllon, most species have an ellipsoid ovary in which the distal $1 / 3$ of the outer cotyledon is folded over the shorter inner cotyledon, which may also be folded on itself distally. Only S. dichotomum has an elongate embryo with straight cotyledons. Convoluted embryos occur in S. bogotense, S. maynense, S. pseudopuberum, S. puberum, and S. sarmentosum.

\section{TAXONOMIC TREATMENT}

Note: Because the height is given on few herbarium labels, it is indicated in brackets in the descriptions presented below. Measurements of flowers and embryos are taken from herbarium material revived with Pohl's solution (Pohl 1965).

\section{STIGMAPHYLLON SUBGENUS RYSSOPTERYS}

\section{Stigmaphyllon subg. Ryssopterys (A.Juss.) C.E.Anderson, comb. \& stat. nov.}

Stigmaphyllon subg. Ryssopterys (A.Juss.) C.E.Anderson. - Ryssopterys A.Juss. in Delessert, Icon. Sel. PI. 3 (1838, '1837') 21, pl. 35. - Type: Stigmaphyllon timoriense (DC.) C.E.Anderson.

Ryssopterys sect. Stenophyllis Nied. (1915) 63. - Type: Ryssopterys angustifolia Nied. [= Stigmaphyllon angustifolium (Nied.) C.E.Anderson].

Perennial vines. Leaves opposite, petiolate; laminas linear, oblong, lanceolate, elliptical, ovate, cordate to orbicular, apex acute, apiculate, acuminate, emarginate, or caudate, base truncate, acute, or cordate, adaxially and abaxially glabrous or pubescent, costa abaxially prominent, secondary veins abaxially prominent or prominulous, tertiary veins abaxially sometimes prominulous; marginal glands commonly present, sometimes absent; petioles with a pair of prominent glands borne at apex or sometimes below apex or partly on the base of the lamina. Stipules interpetiolar, either inconspicuous, triangular, bractlike, $1(-2)$ on each side of petiole, or conspicuous and variously leaflike, $2-3$ on each side of petiole, those nearest the petiole the largest. Plants appearing androdioecious but apparently functionally dioecious, bearing either hermaphrodite or male flowers. Inflorescences axillary; flowers borne in umbels and pseudoracemes, these solitary or commonly arranged in dichasia or compound inflorescences, axes densely sericeous; 
peduncles and pedicels present; bract at base of peduncle, persistent; bracteoles at apex of peduncle, persistent. Flowers radially symmetrical, hermaphrodite (probably functionally female) and male. Sepals 5, elliptical to ovate or suborbicular, apex obtuse, margin ciliate, glabrous to sericeous, eglandular. Petals 5, claw very short or rudimentary or sometimes absent, limb orbicular or broadly obovate, cucullate, margin subentire or shallowly erose, eglandular. Androecium uniseriate; stamens 10 $(-18$, rarely 20$)$, equal or subequal, filaments basally united in a shallow cup; anthers oblong or narrowly elliptical, basifixed, with two thecae, each opening by a longitudinal slit, glabrous or pubescent, the connective well-developed and sometimes drawn out into an apiculum. Gynoecium of hermaphrodite flowers: styles 3 , free to the base, glabrous, stigma terminal, sometimes slightly lateral, peltate; ovary 3-carpellate, 3-loculate, densely pubescent, carpels connate. Gynoecium of male flowers: styles present or absent, if present sometimes $2(-3)$ variously united or occasionally rudimentary, sometimes represented by a short beak; ovary rudimentary, a mound of tissue embedded in a tuft of hairs. Fruit a schizocarp of 3 samaras borne on a pyramidal torus and suspended on carpophores. Samara with a large elongate dorsal wing thickened along the upper (adaxial) margin, nut narrowly ovoid to ellipsoid or spheroid, prominently ribbed and sometimes with lateral winglets and/or spurs, the wall of the locule woody. Embryo narrowly cylindrical or sometimes ovoid, the cotyledons equal or slightly unequal and straight, or embryo ovoid to spherical, the cotyledons folded within each other and convoluted. Chromosome number unknown.

Notes - As noted under Morphology, the species of subg. Ryssopterys can be bewilderingly variable in vegetative and reproductive morphology. Herbarium specimens, especially if incomplete or indifferently prepared, can be difficult to determine. Working through the collections instills a sympathy for the broad approach presented in Flora Malesiana; yet, careful observation reveals the species boundaries. In addition to the key, the following geographic summary may help to narrow the choices. Species listed in parentheses indicate a presumed rare occurrence outside the usual range.

Australia: S. australiense, (S. mariae), S. timoriense.

Indonesia (except New Guinea). Alor: S. sundaicum; Babar:

S. timoriense; Flores: S. albidum, S. sundaicum; Halmahera:

S. micranthum; Java: S. albidum; Morotai: S. timoriense;

Seram: S. micranthum; Sulawesi: S. intermedium, S. micran-

thum, S. timoriense; Sumba: S. albidum, S. sundaicum;

Sumbawa: S. albidum; Tanimbar Islands: S. timoriense;

Ternate: S. micranthum; Timor: S. sundaicum, S. timoriense;

Wetar: S. timoriense.

Micronesia: S. brassii, S. timoriense.

New Caledonia: S. angustifolium, S. discolor, (S. grandifolium), S. gymnopodum, S. mackeeanum, S. mcphersonii, S. taomense, (S. timoriense, fide Guillaumin 1948).

New Guinea: S. abutilifolium (New Ireland), (S. australiense), S. brassii, S. mariae, S. micranthum, S. pullenii, S. papuanum, S. timoriense.

Palau: S. timoriense.

Philippines: S. dealbatum, S. merrillii, S. timoriense.

Ryukyu Islands: (S. timoriense).

Solomon Islands: S. micranthum, (S. discolor), S. solomonense.

Taiwan: (S. timoriense).

Vanuatu: S. grandifolium.

\section{KEY TO THE SPECIES OF}

\section{STIGMAPHYLLON SUBGENUS RYSSOPTERYS}

Note: Regional keys are provided in the Appendix

1. Petiole flanked on each side by $2-3$ stipules, to $4.5 \mathrm{~cm}$ long and leaflike, those next to the petiole the larger, linear to lanceolate to elliptical to ovate or obovate to orbicular, sessile or the largest with a small petiole; in $S$. australiense stipules sometimes represented by a stalked or sessile gland (to 0.5

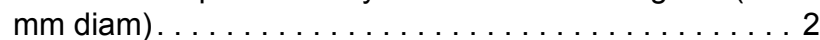

1. Petiole flanked on each side by 1 triangular stipule, to $2.5 \mathrm{~mm}$ long and bractlike (never leafy), in species of New Caledonia occasionally with an additional tiny stipule ( $S$. discolor, S. mackeeanum, and $S$. taomense) or stipules rudimentary (S. angustifolium, S. gymnopodum, S. mcphersonii). . 11

2. Mature laminas abaxially glabrous or glabrate with some hairs retained near major veins and at base, or partly pubescent with patches of tomentum or tufts of hairs $(S$. dealbatum $\ldots \ldots \ldots \ldots \ldots \ldots \ldots \ldots \ldots \ldots$

2. Mature laminas abaxially evenly pubescent, sericeous to

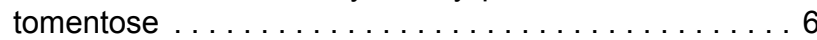

3. Petals $8.5-12 \mathrm{~mm}$ diam; anthers glabrous; bracts $1.5-3$ mm long. - Vanuatu, New Caledonia . 8. S. grandifolium

3. Petals $6-8(-8.5) \mathrm{mm}$ diam; anthers glabrous or pubescent; bracts $1-2 \mathrm{~mm}$ long $\ldots \ldots \ldots \ldots \ldots \ldots \ldots$

4. Mature laminas abaxially with patches of tomentum or tufts of hairs to mostly glabrous, but hairs retained at base and/or on major veins, wavy to crisped and curled, subsessile or with a stalk to $0.1 \mathrm{~mm}$ long; dorsal wing of samara $3-3.8$ cm long. - Philippines . . . . . . . . 6. S. dealbatum

4. Mature laminas abaxially glabrous, any hairs retained at base and/or on major veins straight, sessile, appressed; dorsal wing of samara $2.5-3.3 \mathrm{~cm}$ long . . . . . . . . . 5

5. Stamens 12-16, anthers glabrous; male flowers with 3 styles c. $5 \mathrm{~mm}$ long. - Solomon Islands . . . 18. S. solomonense

5. Stamens 10 (rarely 12), anthers usually pubescent, sometimes sparsely so or rarely glabrous; male flowers without styles (or rarely the rudimentary ovary extended into a beak or bearing rudimentary styles). - Indonesia (Timor and Sulawesi to Papua), Papua New Guinea (Central, Manus, New Ireland), Australia (Queensland), Micronesia, Palau, Philippines to Ryukyu Islands and Taiwan ... 21. S. timoriense

6. Abaxial laminar pubescence appressed, the hairs straight

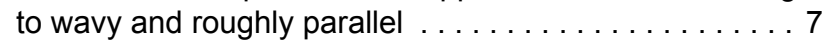

6. Abaxial laminar pubescence spreading, not appressed, the hairs crisped and curled, not parallel . . . . . . . 8

7. Laminas abaxially densely pubescent, the hairs overlapping and the epidermis obscured or nearly so; male flowers without styles; hermaphrodite flowers with styles 2.3-2.5(-3) mm long. - Papua New Guinea, Micronesia (Chuuk) ... .

5. S. brassii

7. Laminas abaxially thinly pubescent, the hairs not or barely touching and the epidermis evident; male flowers without styles or with 3 styles (free or 2 variously united); hermaphrodite flowers with styles c. $3.5 \mathrm{~mm}$ long. - New Guinea, Australia (1 collection from Queensland) .. 12. S. mariae

8. Anthers pubescent; male flowers with 3 styles, variously united. - New Ireland . . . . . . . . . . 1. S. abutilifolium

8. Anthers glabrous; male flowers with or without styles . . 9

9. Petals greenish cream or pale yellow; male flowers with styles; hermaphrodite flowers with styles c. $3 \mathrm{~mm}$ long, stigma terminal but slightly lateral. - Papua New Guinea 17. S. pullenii

9. Petals bright yellow; male flowers without styles; hermaphrodite flowers with styles $1.5-2.8 \mathrm{~mm}$ long, stigma terminal or slightly lateral . . . . . . . . . . . . . . 10 
10. Laminas adaxially glabrous or pubescent, abaxially with sessile or subsessile hairs; hermaphrodite flowers with styles $2.5-2.8 \mathrm{~mm}$ long and filaments $2.5-3 \mathrm{~mm}$ long; male flowers with filaments $2.5-4 \mathrm{~mm}$ long; dorsal wing of samara $1.5-2.8 \mathrm{~cm}$ long. - Australia (3 collections from New Guinea) . . . . . . . . . . . . 4. S. australiense

10. Laminas adaxially glabrous, abaxially with a mixture of subsessile and T-shaped hairs, the stalk to $0.2 \mathrm{~mm}$ long; hermaphrodite flowers with styles $1.5-2 \mathrm{~mm}$ long and filaments 1.7-2 mm long; male flowers with filaments $1.8-2.2 \mathrm{~mm}$ long; dorsal wing of samara $3-3.5 \mathrm{~cm}$ long. — Philippines. . . . . . . . . . . . . . 14. S. merrillii

11. Laminas abaxially tomentose . . . . . . . . . 12

11. Laminas abaxially sericeous or glabrous . . . . . . 14

12. Flowers 4-6 per umbel; stipules rudimentary, to $0.2 \mathrm{~mm}$ long, hidden by the stem vesture; dorsal wing of samara 1.7-2 cm long. - New Caledonia .. 13. S. mcphersonii

12. Flowers $8-25$ per umbel or pseudoraceme; stipules evident, $0.7-2.5 \mathrm{~mm}$ long; dorsal wing of samara $2.3-4.7 \mathrm{~cm}$ long ................. 13

13. Stamens 10 , anthers with prominent apiculum (Java) or with minute apiculum or distally acute (other islands); male flowers without styles; hermaphrodite flowers with styles 1.8-2.2 $\mathrm{mm}$ long, $0.2 \mathrm{~mm}$ diam; dorsal wing of samara 3.5-4.7 cm long. - Java, Flores, Sumba, Sumbawa .. $\ldots \ldots \ldots \ldots \ldots \ldots \ldots \ldots$ 2. S. albidum

13. Stamens 12-16, anthers without apiculum; male flowers with 3 styles (sometimes 2 united and 1 free); hermaphrodite flowers with styles $3.8-4 \mathrm{~mm}$ long, $0.1 \mathrm{~mm}$ diam; dorsal wing of samara $2.3-3 \mathrm{~cm}$ long. - New Caledonia (1 collection from Solomon Islands) . . . . . 7. S. discolor

14. Laminas abaxially sparsely to densely sericeous (in S. intermedium very finely and evenly sericeous but appearing glabrous to the naked eye; in $S$. papuanum the largest laminas eventually glabrate) . . . . . . . . . . . 15

14. Laminas abaxially glabrous or with some scattered hairs at maturity $\ldots \ldots \ldots \ldots \ldots \ldots \ldots \ldots \ldots \ldots \ldots \ldots \ldots$

15. Petals 4-6 mm diam; sepals $1.1-1.5 \mathrm{~mm}$ long . . . 16

15. Petals $7.5-9 \mathrm{~mm}$ diam; sepals $2-3 \mathrm{~mm}$ long . . . . . 17

16. Laminas abaxially densely sericeous, the epidermis obscured or nearly so; male flowers with filaments 1.4-2 $\mathrm{mm}$ long, anthers $0.7-0.8 \mathrm{~mm}$ long; hermaphrodite flowers with styles c. $1 \mathrm{~mm}$ long, c. $0.2 \mathrm{~mm}$ diam. - Sulawesi, Halmahera and Ternate, Seram, New Guinea, Solomon Is-

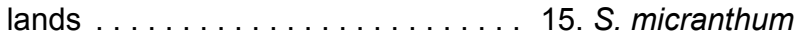

16. Laminas abaxially very finely and evenly sericeous but appearing glabrous to the naked eye, the hairs $0.1-0.4 \mathrm{~mm}$ long, not or barely touching; male flowers with filaments 2.6-2.8 mm long, anthers c. $1.5 \mathrm{~mm}$ long; hermaphrodite flowers unknown. - Sulawesi (?) . . 10. S. intermedium
17. Male flowers without styles; hermaphrodite flowers with styles $1.2-1.5 \mathrm{~mm}$ long, c. $0.2 \mathrm{~mm}$ diam; dorsal wing of samara $3.5-4.5 \mathrm{~cm}$ long. - Papua New Guinea ... . . . ........................ 16. S. papuanum

17. Male flowers with 3 styles, free or variously united; hermaphrodite flowers with styles $3.5-4.2 \mathrm{~mm}$ long, c. 0.1 $\mathrm{mm}$ diam; dorsal wing of samara $2.2-2.5 \mathrm{~cm}$ long. - New Caledonia ... . . . . . . . . . 20. S. taomense

18. Pedicels entirely glabrous or the basal $1 / 4$ sericeous, red. - New Caledonia . . . . . . . . . . . 9. S. gymnopodum

18. Pedicels densely sericeous, green but the colour obscured by the vesture $\ldots \ldots \ldots \ldots \ldots \ldots \ldots \ldots \ldots \ldots$

19. Petals $9-10 \mathrm{~mm}$ diam; stamens $12-18$; male flowers with styles; dorsal wing of samara $1.8-2 \mathrm{~cm}$ long. - New Caledonia ............... 11. S. mackeeanum

19. Petals $6-7 \mathrm{~mm}$ diam; stamens 10 ; male flowers without styles; dorsal wing of samara (1.8-)2.3-3.6 cm long. 20

20. Flowers $4-8$ per umbel; laminas $0.3-2.7 \mathrm{~cm}$ wide, linear to oblong to narrowly elliptical or narrowly lanceolate; dorsal wing of samara (1.8-) $2.3-2.5 \mathrm{~cm}$ long. - New Caledonia $\ldots \ldots \ldots \ldots \ldots \ldots \ldots \ldots$ 3. S. angustifolium

20. Flowers $10-25$ per umbel or pseudoraceme; laminas 3.7$10 \mathrm{~cm}$ wide, narrowly to broadly ovate to cordate or suborbicular; dorsal wing of samara 3-3.6 cm long. - Sumba, Flores, Alor, East Timor . . . . . . . . 19. S. sundaicum

\section{Stigmaphyllon abutilifolium (A.Juss.) C.E.Anderson, comb. nov. - Map 1}

Stigmaphyllon abutilifolium (A.Juss.) C.E.Anderson. - Ryssopterys abutilifolia A.Juss., Ann. Sci. Nat., Bot. sér. 2, 13 (1840) 286. — Type: D’Urville s.n. (holo P), Papua New Guinea, New Ireland.

Ryssopterys dealbata var. tomentosa Nied. (1915) 58. - Type: Peekel 307 (holo B十), Papua New Guinea, Neu-Mecklenburg [= New Ireland], Namatanai.

Vine; stems sericeous when young, eventually glabrescent. Lamina [only one leaf seen] 14 by $8.5 \mathrm{~cm}$, ovate, apex apiculate, base cordate, adaxially glabrous, abaxially sericeous, the hairs $0.4-0.9 \mathrm{~mm}$ long, wavy to crisped, subsessile, touching and overlapping, secondary veins prominent abaxially; marginal glands $0.4 \mathrm{~mm}$ diam; petiole $3 \mathrm{~cm}$ long, densely sericeous, with a pair of glands borne at apex, each gland $1.5 \mathrm{~mm}$ diam, slightly prominent; stipules not seen but probably leaflike, stipule scars 2 on each side of petiole. Hermaphrodite flowers not seen. Male flowers 15-40 in each pseudoraceme, borne in a compound inflorescence, peduncles $4.5-7.5 \mathrm{~mm}$ long, pedicels $3.5-4.5$ $\mathrm{mm}$ long, both densely sericeous, peduncles $1.2-1.8$ times as long as pedicels; bracts $1.2-1.5$ by $0.7-1 \mathrm{~mm}$, narrowly triangular, bracteoles $0.8-0.9$ by c. $0.5 \mathrm{~mm}$, narrowly triangular, bracts and bracteoles abaxially with scattered hairs. Sepals c. 2.2 $\mathrm{mm}$ long and wide, broadly ovate, sparsely sericeous in basal

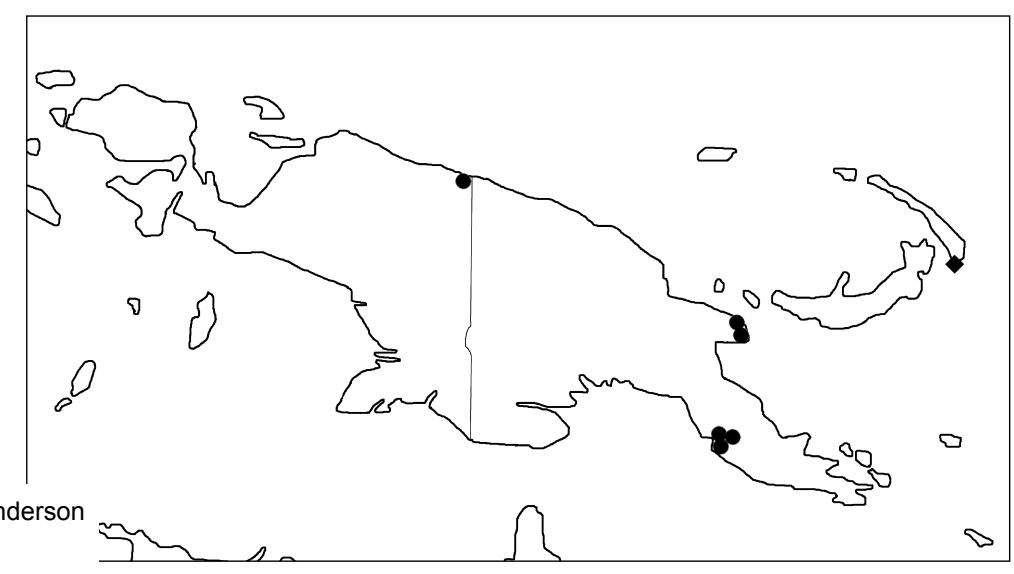

Map 1 Distribution of Stigmaphyllon abutilifolium (A.Juss.) C.E.Anderson ) and S. pullenii C.E.Anderson (-) 
$1 / 3$ or glabrate. Petals yellow, claw c. $0.5 \mathrm{~mm}$ long, limb c. 7 $\mathrm{mm}$ long and wide, base acute, margin subentire or shallowly erose. Stamens 10; filaments 3.4-3.5 mm long; anthers 1-1.1 $\mathrm{mm}$ long, without apiculum, pubescent. Ovary rudimentary, embedded in a tuft of hairs; styles 3 but 2 variously united, c. $3.5 \mathrm{~mm}$ long, single styles c. $0.1 \mathrm{~mm}$ diam, stigma c. $0.3 \mathrm{~mm}$ diam, peltate. Samara not seen.

Notes - Stigmaphyllon abutilifolium is known only from the holotype, consisting of a branchlet bearing one large leaf that is abaxially evenly sericeous and a large compound inflorescence; the male flowers have abundantly pubescent anthers and three styles, two of which are partly or completely united. In the other two species with pubescent anthers, $S$. dealbatum of the Philippines and the widespread S. timoriense, the laminas are glabrate to glabrous at maturity. Styles are absent in male flowers of $S$. timoriense and present but free in those of $S$. dealbatum. No stipules remain on the type; however, the scars indicate that the petiole was flanked on each side by two stipules, which may imply that the stipules are leaflike. In species with triangular bractlike stipules a second stipule is found only occasionally in some species of New Caledonia.

The two other collections seen from New Ireland are S. timoriense (Coode et al. NGF 29615, A, BRI, CANB, E, SING; Croft \& Lelean LAE 65393, A, BRI, CANB). A collection with male flowers from Kabaena, McDonald \& Ismail 4120 (A, CANB, SING), may belong to $S$. abutilifolium. The laminas, though differing in shape from the type, bear a similar if denser abaxial vesture, and the anthers are copiously pubescent; however, the flowers lack styles.

Niedenzu's variety tomentosa is here assigned to $S$. abutilifolium, although the type, from New Ireland, is no longer extant. The placement with Ryssopterys dealbatum implies the presence of pubescent anthers; Niedenzu's brief description and the epithet emphasize the presence of abaxial laminar vesture.

\section{Stigmaphyllon albidum (Blume) C.E.Anderson, comb. nov.} - Map 2

Stigmaphyllon albidum (Blume) C.E.Anderson. - Heteropterys albida Blume, Bijdr. Fl. Ned. Ind. (1825) 226. - Ryssopterys microstema A.Juss. (1843) 384, nom. superfl. Ryssopterys albida (Blume) Merr. (1923) 382. - Type: Blume s.n. (holo L; iso P-JU), Java.

Banisteria tiliifolia Vent. (1808) 50, non Stigmaphyllon tiliifolium Nied. (1900) 16. - Ryssopterys tiliifolia (Vent.) A.Juss. (1840) 286. - Ryssopterys timoriensis var. tiliifolia (Vent.) K.Schum. (in K.Schum. \& Lauterb. 1905) 283. - Type: based on a living specimen cultivated at the Jardin de Cels, source plant collected by Lahaie on Java.

Ryssopterys chrysantha Hassk. (1858) 133. - Type: based on a living specimen grown at the Bogor Botanical Garden, source plant collected by Teijsmann in 1853 from islands off the coast of 'Japara' [= Jepara], Java.

Vine [to $25 \mathrm{~m}$ ]; stems sericeous when young, becoming glabrate to glabrous in age. Laminas of the larger leaves $6-19.5$ by $4-15 \mathrm{~cm}$, narrowly to broadly ovate to cordate, apex apiculate to acuminate to caudate, base truncate to cordate, adaxially sericeous when very young but soon glabrate to glabrous, abaxially tomentose, the hairs $0.5-1.3 \mathrm{~mm}$ long, wavy to crisped to curled, sessile or subsessile or with a stalk to 0.05 $\mathrm{mm}$ long, in the largest laminas the hairs often straight to wavy but crisped and curled at base near costa and petiole, secondary veins prominent abaxially; marginal glands $0.2-0.5$ $\mathrm{mm}$ diam; petioles $1.5-10 \mathrm{~cm}$ long, densely sericeous, with a pair of glands borne at apex, each gland 1-3 mm diam, cupshaped, projecting up to $1 \mathrm{~mm}$ above epidermis, rarely with an additional gland to $1 \mathrm{~mm}$ diam; stipules 1 on each side of petiole, triangular, bractlike, $1-2.5$ by $0.6-1.5 \mathrm{~mm}$, abaxially densely sericeous. Hermaphrodite flowers c. 15-25 in each umbel, borne in dichasia or compound inflorescences; peduncles 5.5-12 mm long, pedicels $3-5 \mathrm{~mm}$ long, both densely sericeous, peduncles 1.3-4 times as long as pedicels; bracts $0.7-1.7$ by $0.5-1 \mathrm{~mm}$, triangular, bracteoles $0.6-1$ by $0.4-0.8$ $\mathrm{mm}$, oblong, bracts and bracteoles abaxially with scattered hairs. Sepals $2-2.5$ by $1.5-2 \mathrm{~mm}$, ovate or broadly elliptical, abaxially sericeous but the distal $1 / 4-1 / 3(-1 / 2)$ often glabrous. Petals yellow, claw $0.5-1 \mathrm{~mm}$ long, limb 7-8 $\mathrm{mm}$ long and wide, base briefly truncate, margin shallowly erose. Stamens 10; filaments $1.7-2 \mathrm{~mm}$ long, anthers $1.5-1.7 \mathrm{~mm}$ long including apiculum (0.2-0.5 $\mathrm{mm}$ long) or apiculum absent or the apex merely acute, glabrous. Ovary $1.5-1.6 \mathrm{~mm}$ long; styles 1.8-2.2 $\mathrm{mm}$ long, $0.2 \mathrm{~mm}$ diam, stigma $0.5-0.7 \mathrm{~mm}$ diam, peltate. Male flowers: filaments $2.3-2.5 \mathrm{~mm}$ long, anthers $1.5-1.7 \mathrm{~mm}$ long including apiculum (0.1-0.5 mm long) or the apex merely acute, glabrous; ovary absent or rudimentary, a mound of tissue to 0.3 $\mathrm{mm}$ long embedded in a tuft of hairs, styles absent. Dorsal wing of samara $3.5-4.7$ by $1.3-2 \mathrm{~cm}$; nut $7.8-9 \mathrm{~mm}$ long, $5.5-6.5$ $\mathrm{mm}$ diam, with prominent ridges and spurs, broadly ovoid to spheroid, lateral winglets absent, areole $3.5-5$ by $3.5-4.3$ $\mathrm{mm}$. Embryo c. 6.3 by c. $4.2 \mathrm{~mm}$, broadly ovoid, the cotyledons convoluted and folded within each other.

Distribution - Indonesia (Java, Flores, Sumba, Sumbawa).

Habitat \& Phenology - Altitude 100-1 $000 \mathrm{~m}$; in forest and secondary vegetation; collected in flower in August to November and January to May, in fruit from February to July.

Notes - Stigmaphyllon albidum has triangular stipules and abaxially tomentose, cordate laminas, a combination found otherwise only in the New Caledonia endemics S. discolor and S. mcphersonii. The hermaphrodite flowers have very short thick styles (1.8-2.2 $\mathrm{mm}$ long, $0.2 \mathrm{~mm}$ diam), but male flowers lack styles. This species is often characterized by the apiculum borne on the anthers; however, this character has proved to be variable. The apiculum is well developed in all collections from Java, but less so in some collections from the other islands, in which it may be only up to $0.1 \mathrm{~mm}$ long; rarely the connective is merely acute at the apex. Stigmaphyllon albidum is one of three species with an ovoid embryo in which the cotyledons are convoluted and folded within each other; $S$. intermedium and $S$. sundaicum also share the triangular bractlike stipules but not the tomentose laminar vesture.

The earliest name for this species is Banisteria tiliifolia Vent., and since Jussieu's circumscription of Ryssopterys it has been known as $R$. tiliifolia, a name often misapplied to other species with densely pubescent laminas. Because the specific epithet is already occupied in Stigmaphyllon (S. tiliifolium Nied.), the next oldest name, Heteropterys albida, is here transferred to Stigmaphyllon. Unfortunately, this transfer may cause additional

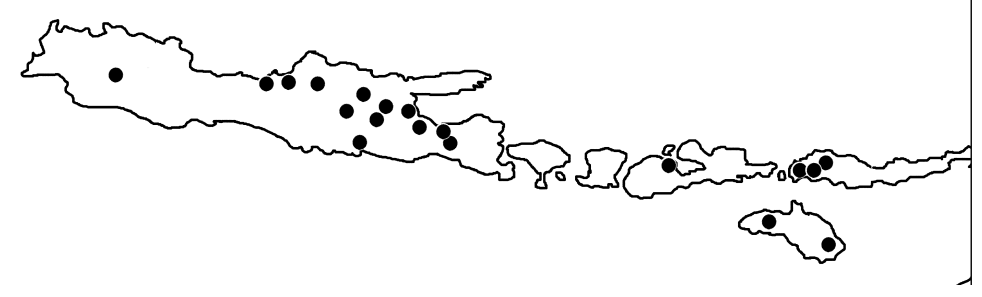

Map 2 Distribution of Stigmaphyllon albidum (Blume) C.E.Anderson. 
confusion; the combination Ryssopterys albida was proposed by Merrill $(1915,1923)$, who applied the name to the Philippine species that here is described as Stigmaphyllon merrillii; see the notes for that species.

\section{Stigmaphyllon angustifolium (Nied.) C.E.Anderson, comb. nov. - Map 3}

Stigmaphyllon angustifolium (Nied.) C.E.Anderson. - Ryssopterys angustifolia Nied., Arbeiten Bot. Inst. Königl. Lyceum Hosianum Braunsberg 6 (1915) 63. - Type: Deplanche 270 (holo B†; lecto, designated here, K), New Caledonia, Cap Devert.

Vine [to $5 \mathrm{~m}$ ]; stems sparsely sericeous when young, eventually glabrate to glabrous. Laminas of the larger leaves $3-6.5$ by $0.3-2.7 \mathrm{~cm}$, linear to oblong to narrowly elliptical or narrowly lanceolate, apex obtuse or slightly emarginate or minutely apiculate, base acute or truncate, adaxially glabrous, abaxially very sparsely sericeous to glabrate or glabrous and sometimes with some hairs retained on the costa, the hairs $0.3-0.8 \mathrm{~mm}$ long, straight, sessile, secondary veins sometimes prominulous abaxially; marginal glands absent; petioles $0.4-2 \mathrm{~cm}$ long, densely sericeous, with a pair of glands borne at apex, each gland 0.5-0.8 mm diam, discoid or slightly prominent; stipules 1 on each side of petiole, rudimentary, triangular, bractlike, $0.1-0.2$ by $0.1-0.3 \mathrm{~mm}$, often hidden by the stem vesture, glabrous or with a few scattered hairs. Hermaphrodite flowers 4-8 in each umbel, solitary or sometimes borne in dichasia; peduncles (1.2-) $4-7.5 \mathrm{~mm}$ long, pedicels $3-8.5 \mathrm{~mm}$ long, both densely sericeous, peduncles (0.3-)0.6-1.5(-2) times as long as pedicels; bracts $0.8-1$ by $0.4-0.8 \mathrm{~mm}$, narrowly triangular, bracteoles $0.6-0.8$ by $0.4-0.5 \mathrm{~mm}$, linear to oblong, bracts and bracteoles abaxially with scattered hairs or sometimes glabrous. Sepals 1.3-2 mm long and wide, suborbicular to broadly ovate, sparsely sericeous, or only in the proximal half or near the base and otherwise glabrous. Petals yellow, claw absent to $0.5 \mathrm{~mm}$ long, limb 6-7 mm long and wide, base acute, margin subentire or shallowly erose. Stamens 10; filaments 1-1.2 mm long, anthers 1.1-1.2 mm long, without apiculum, glabrous. Ovary 1.5-1.7 mm long; styles 3-3.5 mm long, 0.15(-0.2) $\mathrm{mm}$ diam, stigma $0.3 \mathrm{~mm}$ diam, peltate. Male flowers: filaments $1.5-1.8(-3) \mathrm{mm}$ long, anthers c. $1.2 \mathrm{~mm}$ long, without apiculum, glabrous; ovary rudimentary, a mound of tissue to $0.7 \mathrm{~mm}$ long embedded in a tuft of hairs; styles absent, rarely present but then 2 variously united and 1 free, or all 3 united into 1 structure with a broad 3-lobed peltate stigma. Dorsal wing of samara $1.8-2.5$ by $0.8-1 \mathrm{~cm}$, upper margin without a tooth; nut $5-6$ $\mathrm{mm}$ long, c. $4.5 \mathrm{~mm}$ diam, ovoid, prominently ribbed, winglets absent, areole 2-3.5 mm long and wide. Embryo 4.3-4.7 mm long, ovoid; outer cotyledon $4-4.3$ by $3-3.3 \mathrm{~mm}$, slightly curved distally, inner cotyledon $3.3-4$ by c. $2.5 \mathrm{~mm}$, straight.

Distribution - New Caledonia.

Habitat \& Phenology - Altitude from sea level to $650 \mathrm{~m}$; in forest and thickets, often on serpentine; collected in flower from November to April, in fruit from January to May.

Note - Stigmaphyllon angustifolium is named for its unusually narrow laminas, which vary from linear and $0.3 \mathrm{~cm}$ wide to narrowly elliptical or narrowly lanceolate and $2.7 \mathrm{~cm}$ wide, a distinction that led Niedenzu $(1915,1928)$ to assign this species to a separate section in Ryssopterys (sect. Stenophyllis). The laminas are essentially glabrous and lack marginal glands. The minute stipules are often hidden by the stem pubescence.

\section{Stigmaphyllon australiense (Nied.) C.E.Anderson, comb. nov. - Map 4}

Stigmaphyllon australiense (Nied.) C.E.Anderson. - Ryssopterys australiensis Nied., Arbeiten Bot. Inst. Königl. Lyceum Hosianum Braunsberg 6 (1915) 61. - Type: Mueller s.n. (syn B†), Australia, Queensland, Endeavour River and Rockingham Bay; Warburg 19012 (syn B十), Australia, Queensland, Carrus [Cairns?] Camerunga [Kamerunga]; unknown collector s.n. (syn $\mathrm{B \dagger}$ ), Australia, Queensland, Lizard Island. — Neo: Forster 9639 (neo, here designated, L; isoneo BRI), Australia, Queensland, Forty Mile Scrub, S of Mt Garnet, $18^{\circ} 07^{\prime} \mathrm{S}, 1^{\circ} 4^{\circ} 49^{\prime} \mathrm{E}, 780$ m, 30 Jan. 1992.

Ryssopterys australiensis forma elongata Nied. (1915) 62. - Ryssopterys discolor forma elongata (Nied.) Nied. (1928) 286. - Type: Mueller s.n. (holo B十), Australia, Queensland, Rockingham Bay.

Ryssopterys australiensis forma stipulacea Nied. (1915) 62. - Ryssopterys discolor forma stipulacea (Nied.) Nied. (1928) 286. - Type: Mueller s.n. [Dallachy] (holo B†; lecto, here designated, C), Australia, Queensland, Rockingham Bay.

Vine [to $10 \mathrm{~m}$ ]; stems densely tomentose when young, the vesture sparser in older parts, eventually glabrate to glabrous. Laminas of the larger leaves $6-14$ by $4.5-11.5 \mathrm{~cm}$, lanceolate to narrowly to broadly ovate to broadly elliptical or suborbicular, apex apiculate or obtuse-apiculate, base cordate to auriculate, adaxially and abaxially densely tomentose, adaxially remaining tomentose or with age sparsely so to glabrate or glabrous but usually with some hairs retained on the major veins toward the base, hairs $0.4-1.1 \mathrm{~mm}$ long, subsessile; secondary veins prominent abaxially; marginal glands $0.3-0.5 \mathrm{~mm}$ diam; petioles $1.5-4.5 \mathrm{~cm}$ long, densely tomentose, with a pair of glands at apex or up to $3 \mathrm{~mm}$ below the lamina base, each gland $0.7-1.5 \mathrm{~mm}$ diam, prominent; stipules $2-3$ on each side of the petiole, leaflike, the largest divided into a petiole to $6.5 \mathrm{~mm}$ long and a lamina $1-2$ by c. $2 \mathrm{~cm}$, elliptical to oblate or reniform, the

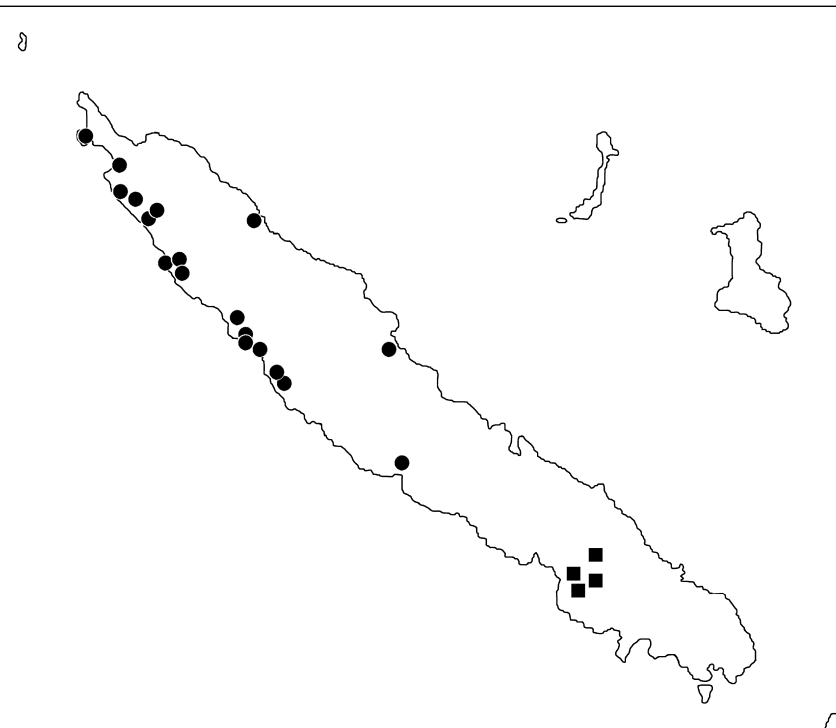

Map 3 Distribution of Stigmaphyllon angustifolium (Nied.) C.E. Anderson $(\bullet)$ and S. mcphersonii C.E. Anderson (ם) 


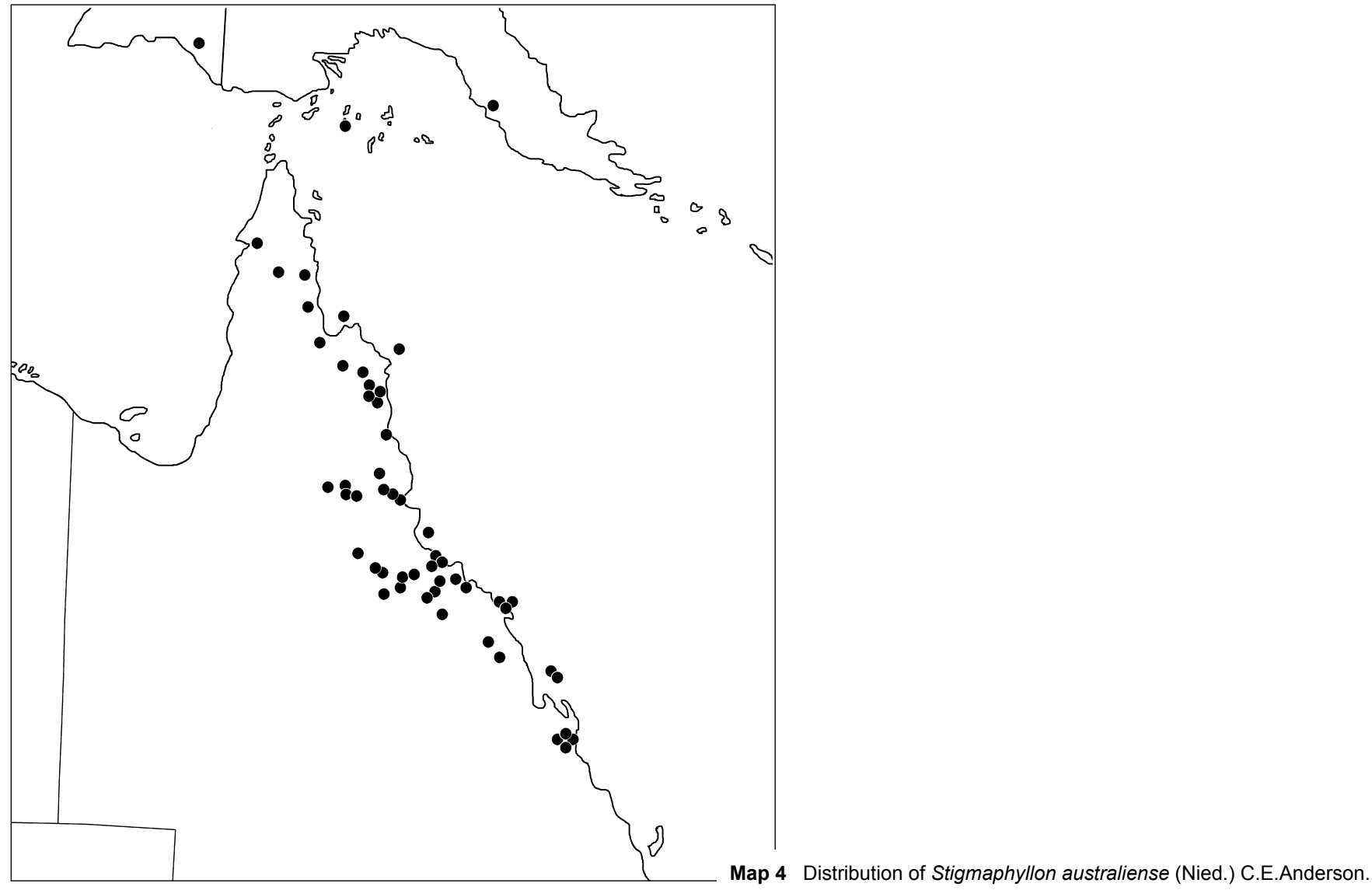

smaller sessile and $1.5-7$ by $0.5-2 \mathrm{~mm}$, elliptical to linear, the smallest often hidden by the dense stem pubescence, apex commonly minutely glandular, sometimes the gland enlarged to $0.5 \mathrm{~mm}$ diam and borne on a stalk or rarely the enlarged gland sessile. Hermaphrodite flowers 10-15(-20) in each umbel or pseudoraceme, borne in dichasia or compound inflorescences, peduncles $3-6(-12) \mathrm{mm}$ long, pedicels $2.5-4.5 \mathrm{~mm}$ long, both densely tomentose, peduncles $1-2(-3)$ times as long as pedicels; bracts $1.2-1.8$ by $0.5-0.8 \mathrm{~mm}$, narrowly triangular, bracteoles $0.7-1.5$ by $0.5-0.8 \mathrm{~mm}$, oblong, bracts and bracteoles abaxially sparsely sericeous. Sepals $2-3$ by $2-2.5 \mathrm{~mm}$, elliptical or ovate, glabrous or sparsely sericeous, or sericeous only in the centre and the rest glabrous. Petals yellow, claw $0.5-1 \mathrm{~mm}$ long, limb 7-8 $\mathrm{mm}$ long and wide, base truncate, margin shallowly erose. Stamens $10(-12)$; filaments $2.5-3$ $\mathrm{mm}$ long; anthers 1-1.1 mm long, without apiculum, glabrous. Ovary c. $1.5 \mathrm{~mm}$ long; styles $2.5-2.8 \mathrm{~mm}$ long, c. $0.1 \mathrm{~mm}$ diam, stigma $0.3-0.4 \mathrm{~mm}$ diam, peltate but laterally positioned. Male flowers: filaments $2.5-4 \mathrm{~mm}$ long; anthers $1-1.4 \mathrm{~mm}$ long, without apiculum, glabrous; ovary rudimentary, a mound of tissue $0.3-0.5 \mathrm{~mm}$ long embedded in a tuft of hairs; styles absent, or rarely present and variously united or rudimentary. Dorsal wing of samara $1.5-2.8$ by $0.7-1.3 \mathrm{~cm}$; nut $6-7 \mathrm{~mm}$ long, 3.5-4 mm diam, narrowly ovoid, with 1-3 lateral winglets and/or prominent ridges and/or spurs, winglets $1.5-6$ by $1-3$ $\mathrm{mm}$; areole $3.5-4.5$ by $1.7-2 \mathrm{~mm}$. Embryo c. $7 \mathrm{~mm}$ long, narrowly cylindrical, cotyledons unequal, outer cotyledon c. $6 \mathrm{~mm}$ long, inner cotyledon c. $4.5 \mathrm{~mm}$ long, both straight.

Distribution - Australia (Queensland, New South Wales?); New Guinea.

Habitat \& Phenology - Altitude from sea level to $1000 \mathrm{~m}$; in rain forest, thickets, deciduous vine-forest, shrubland, and forest near beach front; collected in flower from December to June, in fruit from February to September.

Notes - Stigmaphyllon australiense is distinctive in its abundant tomentose pubescence covering all vegetative parts. The adaxial vesture of the laminas may be retained at maturity or is variably sloughed off, though commonly some hairs are retained on the costa or patchily on the surface. The apex of a stipule is extended into a minute glandular tip, but occasionally the stipule is transformed into a stalked or sessile gland to $0.5 \mathrm{~mm}$ diam (e.g., Batianoff 11368, Bean 3303, Fensham 1, all BRI). Styles are usually absent in male flowers but occasionally are present, e.g., in Clarkson 6353 (BRI, L) two of the three styles are variously united in the distal 1/2; in Foster \& Ryan 18369 (BRI) flowers have one rudimentary style, c. $0.7 \mathrm{~mm}$ long and without a stigma.

Stigmaphyllon australiense is commonly found in Queensland, but occurs also in New Guinea, as attested by three collections: Brass 3672 (A, BRI, NY), Papua New Guinea, Central Province, Rona; Soegeng Reksodihardjo 203 (L), Indonesia, Papua, Merauke; Womersley NGF 43648 (A, BRI, E, K, NSW, SING, US), Papua New Guinea, Madang Province, Long Island, near Matafuna village. A collection from Australia (Jeswiet 21, WAG) is said to be from New South Wales but lacks locality data ("langs spoorlijn van Sydney naart Noorden").

None of Niedenzu's syntypes are extant, and therefore a neotype is designated. Most of the collections seen by me were originally determined as Ryssopterys timoriensis [= S. timoriense], which has glabrous leaves and usually pubescent anthers.

\section{Stigmaphyllon brassii C.E.Anderson, sp. nov. - Fig. 2;} Map 5

Differt a S. micrantho stipulis foliosis, sepalis (2-)2.3-2.5 mm longis, stylis 2.3-2.5(-3) mm longis. - Typus: Brass 29308 (holo A; iso CANB, L, NY) Papua New Guinea, Morobe, Oomsis, 100 m, 29 Apr. 1959.

Etymology. This species is named for Leonard John Brass (1900-1971) whose valuable collections obtained during expeditions to New Guinea, Australia, and the Solomon Islands have contributed greatly to an understanding of the flora of these regions. He collected the type during the sixth Archbold expedition. 

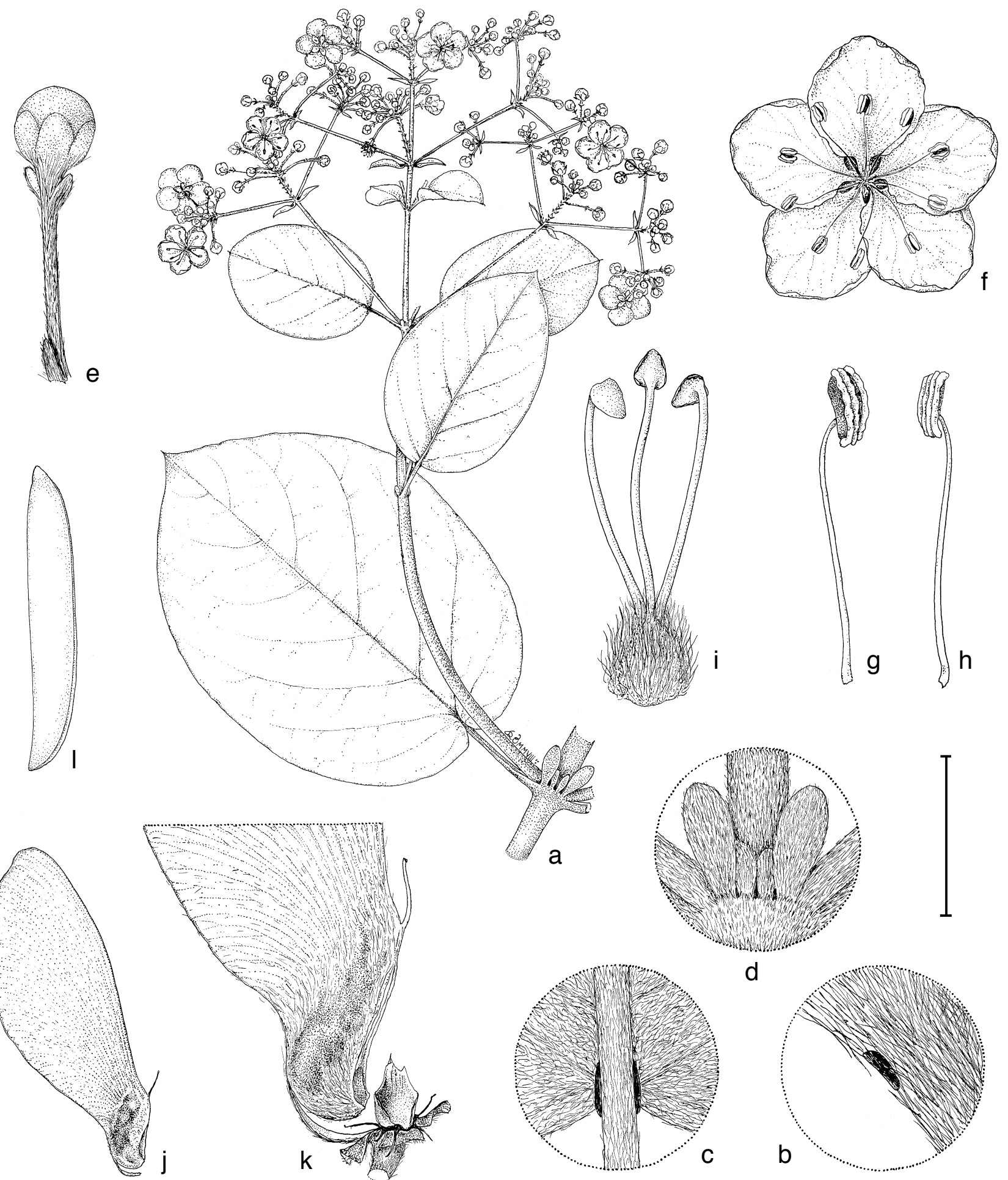

Fig. 2 Stigmaphyllon brassii C.E.Anderson. a. Flowering branch; b. detail showing abaxial surface of lamina and marginal gland; c. base of lamina with pair of glands; d. node with stipules; e. flower bud with peduncle and pedicel; f. flower; g. stamen from male flower; h. stamen from hermaphrodite flower; i. gynoecium; j. samara; $k$. base of samara with carpophore attached to torus; I. embryo. - Scale bars: $a=4 \mathrm{~cm} ; \mathrm{b}, \mathrm{g}-\mathrm{i}=2 \mathrm{~mm} ; \mathrm{c}, \mathrm{k}=8 \mathrm{~mm} ; \mathrm{d}=1.3 \mathrm{~cm}$; $\mathrm{e}=5.7 \mathrm{~mm} ; \mathrm{f}=8 \mathrm{~mm} ; \mathrm{j}=2 \mathrm{~cm} ; \mathrm{l}=4 \mathrm{~mm}$ (a-e: Brass 29308, A; f-i: Streimann \& Kairo NGF 27579, CANB; j-l: Hartley 10314, A).

Vine [to $15 \mathrm{~m}$ ]; stems densely sericeous when young, older parts glabrate to glabrous. Laminas of the larger leaves $4.5-14$ by $1.5-9.7 \mathrm{~cm}$, elliptical to broadly elliptical to ovate to broadly ovate to orbicular, apex obtuse or emarginate and apiculate, or distally tapered and briefly acuminate, base shallowly to deeply cordate, adaxially sericeous when young and the hairs abraded in patches, eventually glabrate to glabrous but often the hairs retained on the costa and the major veins, abaxially densely sericeous, the hairs $0.5-1 \mathrm{~mm}$ long, straight or sinuous, sessile or subsessile or with a stalk to $0.05(-0.1) \mathrm{mm}$ long, secondary veins prominent abaxially; marginal glands $0.4-0.5 \mathrm{~mm}$ diam; petioles $1.5-5 \mathrm{~cm}$ long, densely sericeous, with a pair of glands borne at apex, each gland $1.5-3 \mathrm{~mm}$ diam, slightly prominent; stipules 2 on each side of petiole, leaflike, larger stipules to 9.5 $\mathrm{mm}$ long, to $7 \mathrm{~mm}$ wide, elliptical to obovate, smaller stipules to $5.5 \mathrm{~mm}$ long, to $1.5 \mathrm{~mm}$ wide, linear to oblong. Hermaphrodite flowers 15-35 in each pseudoraceme, borne in dichasia or compound inflorescences; peduncles 2-11.5 mm long, pedicels $4-8 \mathrm{~mm}$ long, both densely sericeous, peduncles $(0.7-) 1-2.5(-2.8)$ times as long as pedicels; bracts $0.8-1.5$ by $0.5-0.7(-1) \mathrm{mm}$, narrowly triangular, bracteoles $0.9-1.2$ by $0.5-0.8 \mathrm{~mm}$, oblong, bracts and bracteoles abaxially sericeous. Sepals (2-)2.3-2.5 by $1.5-2 \mathrm{~mm}$, oblong, abaxially sericeous or sparsely so, commonly glabrous near the margin or some- 


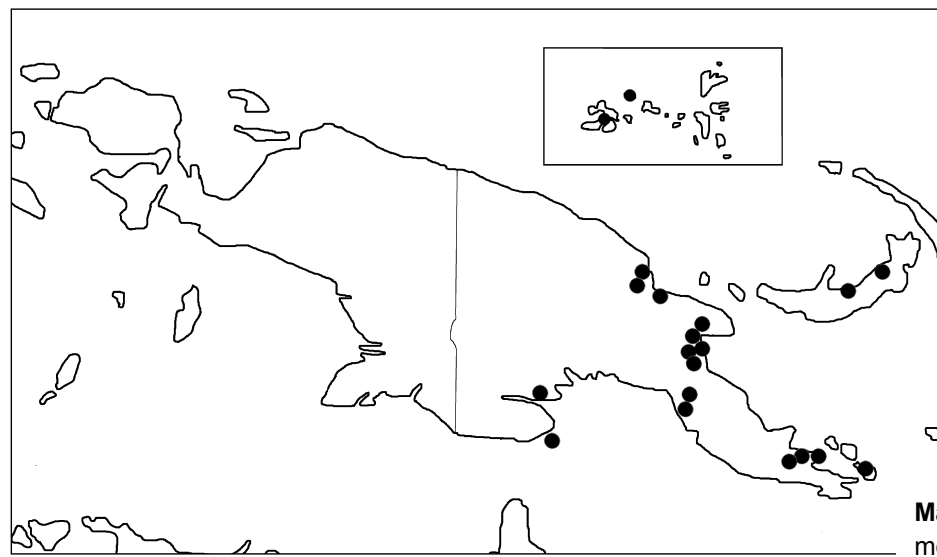

$\square$

Map. 5 Distribution of Stigmaphyllon brassii C.E. Anderson (inset: Chuuk, Solomon Islands).

times entirely glabrous. Petals yellow, claw $0.3-0.8(-1) \mathrm{mm}$ long, limb $5.5-7$ by $5-7 \mathrm{~mm}$, base truncate, margin shallowly erose. Stamens 10; filaments $2.5-3(-3.5) \mathrm{mm}$ long; anthers $1-1.1 \mathrm{~mm}$ long, without apiculum or with a tiny apiculum to 0.1 $\mathrm{mm}$ long, glabrous. Ovary c. $1.5 \mathrm{~mm}$ long; styles $2.3-2.5(-3)$ $\mathrm{mm}$ long, c. $0.1 \mathrm{~mm}$ diam, stigma $0.3-0.4 \mathrm{~mm}$ diam, triangularpeltate. Male flowers $15-30(-50)$ per pseudoraceme; filaments 2.8-3.5 mm long, anthers $1-1.1 \mathrm{~mm}$ long, without apiculum, glabrous; ovary rudimentary, a mound of tissue to $0.1 \mathrm{~mm}$ high or sometimes three minute such structures embedded in a tuft of white hairs, styles absent or sometimes present, to $3(-3.5)$ $\mathrm{mm}$ long, free or variously united, stigma of free style c. $0.3 \mathrm{~mm}$ diam. Dorsal wing of samara $3-4.5$ by $1.4-1.7 \mathrm{~cm}$; nut $8-9.5$ $\mathrm{mm}$ long, 3.5-4 mm diam, narrowly ovoid, with prominent ridges and/or spurs, lateral winglets absent; areole $7-8$ by $2-2.3$ $\mathrm{mm}$. Embryo 7-8 by c. $2 \mathrm{~mm}$, narrowly cylindrical, cotyledons subequal or slightly unequal, outer cotyledon $6-7.5$ by $1.5-2$ $\mathrm{mm}$, inner cotyledons $6.5-6.6$ by $1.5-1.8 \mathrm{~mm}$, both straight.

Distribution - Papua New Guinea (Central, Eastern Highlands, Madang, Milne Bay, Morobe, National Capital, West New Britain, Western), Micronesia (Chuuk).

Habitat \& Phenology - Altitude from sea level to $1000 \mathrm{~m}$; rain forest, scrub above beach, secondary vegetation; collected in flower from November to June, in fruit from April to June and in August.

Additional specimens examined. Federated States of Micronesia, Chuuk, Tol Island, 24 May 1946, Hosaka 2720 (L); Tol Island, 30 Jan. 1965, Stone 5321 (L); Ulalu (Romomum), 2 Oct. 1947, Wong 177 (A, US). - PAPUA NeW GuineA, Central, Baroka, Nakeo Distr., 30 m, 8 Apr. 1933, Brass 3728 (A, BRI, NY); Baroka, Nakeo Distr., 30 m, 10 Apr. 1933, Brass 3767 (A, BRI, NY); Tapini area, Tapini Subdistr., $08^{\circ} 18^{\prime} \mathrm{S}, 146^{\circ} 48^{\prime} \mathrm{E}, 3000 \mathrm{ft}, 1-4$ May 1971 , Lelean NGF 46372 (A, BRI, CANB, K, NSW, SING). Eastern Highlands, Bulolo, Morobe Distr., 07 $10^{\prime}$ S, 146 $40^{\circ} \mathrm{E}, 2300$ ft, Apr. 1957, Womersley NGF 9095 (BRI, CANB, L, SING). Madang, Subdistr. Madang, Bau, on rd from Madang to Utu, $05^{\circ} 10^{\prime} S, 145^{\circ} 44^{\prime} \mathrm{W}, 500 \mathrm{ft}, 6$ Mar. 1968, Coode \& Katik NGF 32735 (A, BRI, CANB, E, L, SING); bei Constantinhafen, Mar. 1902, Schlechter 14263 (BR, K, P); Kaiser-Wilhelmsland, am MinjemFluss, $160 \mathrm{~m}$, 10 Apr. 1908, Schlechter 17267 (C, K, L, MO); near Usino, $05^{\circ} 32^{\prime} \mathrm{S}, 145^{\circ} 25^{\prime} \mathrm{E}$, 625 m, 31 Jan. 1978, Takeuchi \& Damas 4431 (A, CANB, L, MO). Milne Bay, between Dabora and Wabubu, Cape Vogel Peninsula, 30 m, 9 Apr. 1953, Brass 21891 (A, CANB, L, US); Baiawa, Moi Biri Bay, 60 m, 8-10 May 1953, Brass 22161 (A, CANB, K, L, US); Normanby Island, Waikaiuna, 20 m, 16 May 1956, Brass 25889 (A, L, US); Igup, 1800 ft, 18 May 1954, Cruttwell 427 (E, K). Morobe, Oomsis, 100 m, 15 Apr. 1959, Brass 29206 (L, US); Salamaua, Malolo Mission, 6-800 ft, 26 Aug. 1935, Clemens 18 (L); T.N.G., Yalu, $06^{\circ} 35^{\prime} \mathrm{S}, 146^{\circ} 52$ 'E, $400 \mathrm{ft}, 13$ June 1962, Hartley 10314 (A, BRI, CANB, K); Bulolo, 07¹0'S, 146²0'E, 2400 ft, 1 May 1962, Millar NGF 14531 (A, BRI, CANB, K, L, NSW); Kalapit Subdistr., Umi River, 06¹5'S, $146^{\circ} 15^{\prime} \mathrm{E}$, $1400 \mathrm{ft}, 10$ Jan. 1963, Millar \& Van Royen NGF 15632 (A, BRI, CANB, L); Bulolo, $07^{\circ} 10^{\prime} \mathrm{S}, 146^{\circ} 40^{\prime} \mathrm{E}, 2300 \mathrm{ft}, 14$ Nov. 1963, Millar NGF 18830 (A, BRI, CANB, E, K, L, NSW, SING); Bulolo, Way Subdistr., 1500 m, 14 Mar. 1976, Moi 14 (CANB, L); Middle L. A. Bulolo, 07¹0'S, 146²0'E, 2600 ft, Apr. 1966, Streimann \& Kairo NGF 27579 (A, BRI, CANB, E, K, L, NSW, SING); vicinity Oomsis Creek, $07^{\circ} 40^{\prime} \mathrm{S}, 146^{\circ} 45^{\prime} \mathrm{E}, 200 \mathrm{ft}$, Apr.-May 1959, Wright NGF 11121 (A, BRI, CANB, K). Western, Daru Island, 6 Apr. 1936, Brass 6442 (A, BRI,
L); Gaima, Lower Fly River, Nov. 1936, Brass 8299 (A, BRI, L). West New Britain, Subdistr. Hoskins, Nantambu, $05^{\circ} 05^{\prime} \mathrm{S}, 151^{\circ} 25^{\prime} \mathrm{E}$, sea level, 8 June 1973, Isles \& Vinas NGF 32384 (A, BRI, CANB, E, K, MO, NSW, SING, US); Subdistr. Hoskins, Miller Mapping Point, $04^{\circ} 57$ 'S, $151^{\circ} 34^{\prime} \mathrm{E}, 345 \mathrm{~m}, 4$ June 1973, Stevens \& Lelean LAE 58536 (A, BRI, CANB, E).

Notes - Stigmaphyllon brassii is distinguished by its abaxially densely sericeous leaves, which immediately separate it from S. pullenii with abaxially tomentose laminas. Styles are usually not present in male flowers but rarely are found and then may be variously united or rudimentary. This species differs from S. micranthum, with which it shares a similar leaf vesture, by its leaflike stipules and larger flowers.

The collections Brass 6442 and Brass 8299 from Western Province are placed here with some hesitation and may represent yet another undescribed species. The laminar pubescence reminds of S. pullenii, and the styles of the hermaphrodite flowers (Brass 8299) bear scattered hairs; however, the male flowers (Brass 6442) lack styles, as in S. brassii but not S. pullenii.

\section{Stigmaphyllon dealbatum (A.Juss.) C.E.Anderson, comb. nov. - Fig. 3; Map 6}

Stigmaphyllon dealbatum (A.Juss.) C.E.Anderson. - Ryssopterys dealbata A.Juss., Arch. Mus. Hist. Nat. 3 (1843) 386. - Type: Cuming 1775 (holo P; iso C, GOET, K, L), The Philippines, Cebu [fide Merrill 1915].

Ryssopterys cumingiana A.Juss. (1843) 386. - Ryssopterys dealbata var. cumingiana (A.Juss.) Nied. (1915) 58. - Type: Cuming 1489 (holo P; iso K, L), The Philippines, Mindoro [fide Merrill 1915].

Vine; stems sericeous when young, soon glabrate to glabrous. Laminas of the larger leaves $4.5-13$ by $3.5-11 \mathrm{~cm}$, ovate or elliptical or broadly so to suborbicular, apex apiculate or briefly acuminate, base cordate or truncate in small laminas, adaxially sparsely tomentulose when very young, soon glabrous, abaxially tomentose when young, the hairs detaching in patches and soon glabrous except for hairs retained near the base and next to or on the major veins, sometimes sparsely pubescent at maturity, the hairs $0.3-1.8 \mathrm{~mm}$ long, wavy to crisped and curled, subsessile or with a stalk to $0.1 \mathrm{~mm}$ long, secondary veins prominent and tertiary veins prominulous abaxially; marginal glands $0.2-0.5(-0.8) \mathrm{mm}$ diam; petioles $2-6.5 \mathrm{~cm}$ long, densely sericeous, with a pair or glands borne at or near the apex, each gland 1-2 mm diam, prominent; stipules 2 on each side of petiole, leaflike, larger stipules to $4.5 \mathrm{~cm}$ long, to $2.5 \mathrm{~cm}$ wide, oblong or obovate, the largest with a petiole to $1 \mathrm{~cm}$ long, smaller stipules to $4 \mathrm{~mm}$ long, to $2.5 \mathrm{~mm}$ wide, strap-shaped, with scattered hairs to glabrous. Hermaphrodite flowers c. 10-30 in each pseudoraceme, borne in dichasia and compound inflorescences; peduncles $2-12.5 \mathrm{~mm}$ long, pedicels $3-9 \mathrm{~mm}$ long, both densely sericeous, peduncles $0.5-1.5(-1.9)$ times as long as pedicels; bracts $1-2$ by $0.5-1.1 \mathrm{~mm}$, narrowly triangular, bracteoles $0.8-1.8$ by $0.5-0.8 \mathrm{~mm}$, oblong, bracts and bracteoles abaxially with scattered hairs. Sepals $2-3$ by 


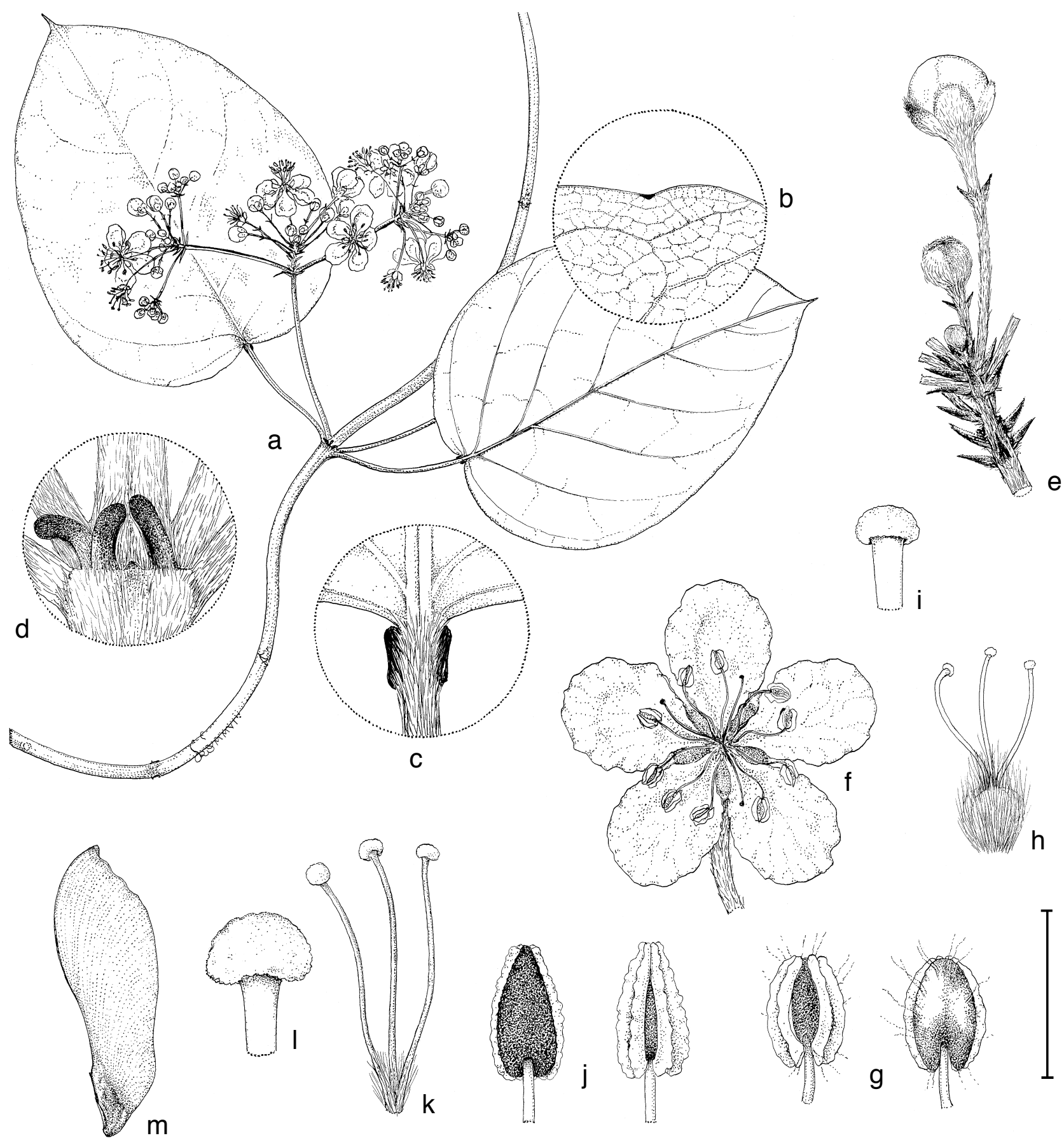

Fig. 3 Stigmaphyllon dealbatum (A.Juss.) C.E.Anderson. a. Flowering branch; b. abaxial lamina margin; c. glands at apex of petiole; d. node near inflorescence with small stipules; e. branch of inflorescence with flower buds; f. hermaphrodite flower; g. anthers from hermaphrodite flower, adaxial view (left) and abaxial view (right); h. gynoecium from hermaphrodite flower; i. stigma from hermaphrodite flower; j. anthers from male flower, abaxial view (left) and adaxial view (right); k. gynoecium from male flower; I. stigma from male flower; $\mathrm{m}$. samara. - Scale bars: $\mathrm{a}=4 \mathrm{~cm} ; \mathrm{b}-\mathrm{d}, \mathrm{h}, \mathrm{k}=4 \mathrm{~mm} ; \mathrm{e}, \mathrm{f}=8 \mathrm{~mm} ; \mathrm{g}, \mathrm{j}=2 \mathrm{~mm} ; \mathrm{i}, \mathrm{l}=$ $0.8 \mathrm{~mm} ; \mathrm{m}=2.7 \mathrm{~cm}$ (a-e, j-l: Ramos \& Edaño s.n. [Philippine Bureau of Science 29136], MO; f-i: Sulit \& Conklin s.n. [Philippine National Herbarium 17620], $\mathrm{K} ; \mathrm{m}$ : Ramos \& Edano BS 49859, $\mathrm{MICH})$.

$1.5-2.5 \mathrm{~mm}$, ovate to broadly ovate, sericeous to glabrous. Petals yellow, claw $0.5-1.5(-2) \mathrm{mm}$ long, limb $7.5-8 \mathrm{~mm}$ long and wide, base acute or briefly truncate, margin subentire or shallowly erose. Stamens 10; filaments (2-)2.5-3(-4) mm long, anthers $1.2-1.5(-1.7) \mathrm{mm}$ long, without apiculum or sometimes with a tiny apiculum to $0.1 \mathrm{~mm}$ or apex acute, pubescent or sparsely so or occasionally glabrous. Ovary 1.6-1.7 $\mathrm{mm}$ long; styles $3.2-4 \mathrm{~mm}$ long, $0.1 \mathrm{~mm}$ diam, stigma $0.3 \mathrm{~mm}$ diam, peltate. Male flowers: filaments $2.5-4.5 \mathrm{~mm}$ long, anthers (1-)1.5-2 mm long, without apiculum or sometimes with a tiny apiculum to $0.1 \mathrm{~mm}$ or apex acute, pubescent or sparsely so or occasionally glabrous; ovary rudimentary, a mound of tissue to $0.4 \mathrm{~mm}$ high embedded in a tuft of hairs; styles usually 3, free, 4.2-5.3 mm long, $0.1 \mathrm{~mm}$ diam, stigma $0.3-0.4 \mathrm{~mm}$ diam, peltate, or sometimes with 2-3 rudimentary styles to 1 $\mathrm{mm}$ long, or occasionally styles absent. Dorsal wing of samara $3-3.8$ by $1.4-1.8 \mathrm{~cm}$; nut c. $10.5 \mathrm{~mm}$ long, c. $4.5 \mathrm{~mm}$ diam, narrowly ovoid, shallowly ridged or nearly smooth, without lateral winglets, areole 8 by $3 \mathrm{~mm}$; mature seed not seen.

Distribution - The Philippines.

Habitat \& Phenology - Altitude from sea level to $550 \mathrm{~m}$; primary forest, beach forest, secondary vegetation; collected in flower from March to September, in fruit in November and January.

Notes - The laminas of $S$. dealbatum are abaxially tomentose when young, but commonly the vesture is soon sloughed off, and mature laminas are abaxially glabrous or glabrate; sometimes patches of hairs remain on the surface. Some of 


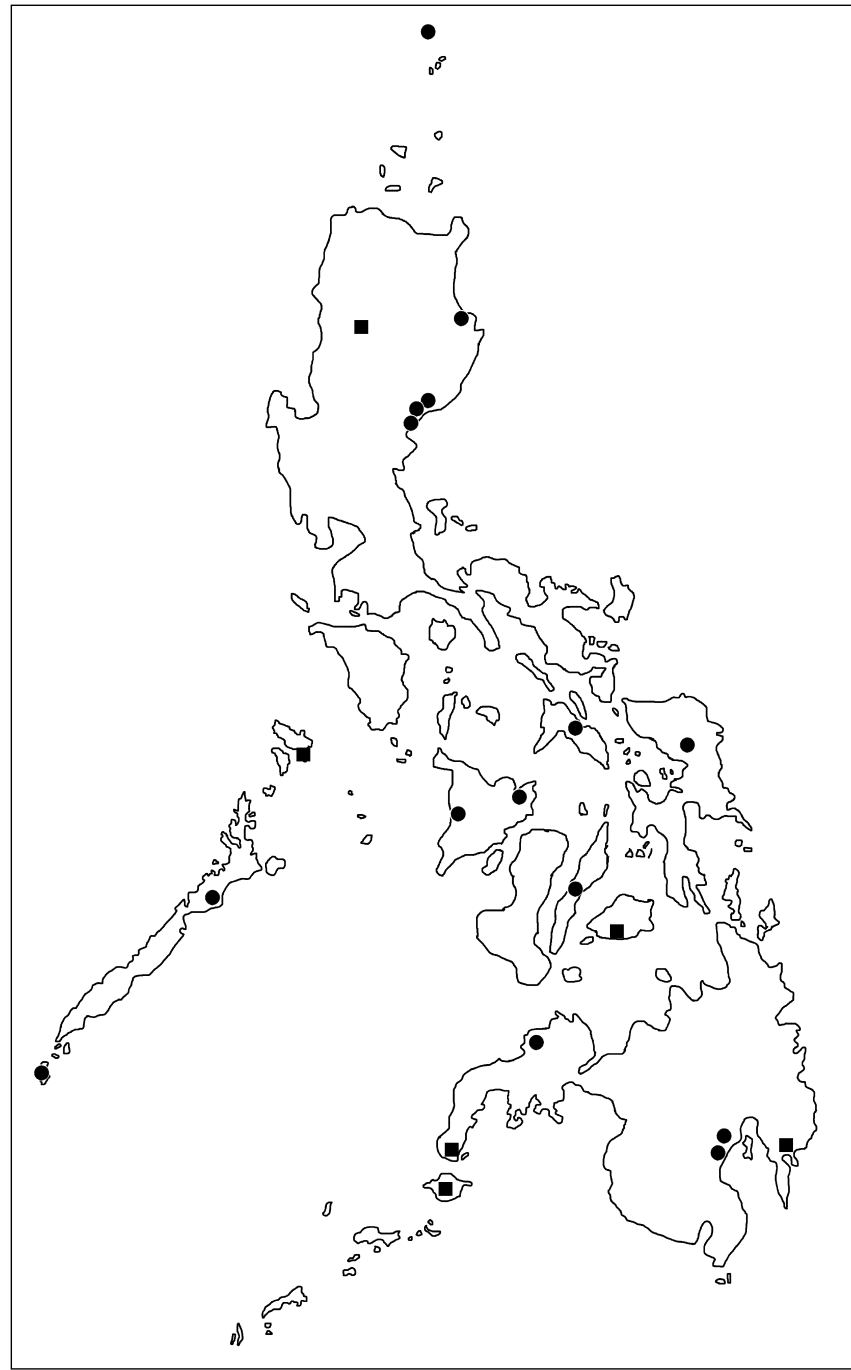

Map 6 Distribution of Stigmaphyllon dealbatum (A.Juss.) C.E.Anderson ( and S. merrillii C.E.Anderson ( $\square$ ).

the crisped and curled hairs are always retained at the base of the lamina and on the major veins. As in S. timoriense, the other species with glabrous leaves found in the Philippines, the anthers are pubescent, although occasional individuals with glabrous anthers are found in both species. In S. timoriense the young laminas are sericeous abaxially and soon glabrous; any hairs retained are straight and tightly appressed. Styles are usually absent in male flowers of $S$. timoriense but usually present in those of $S$. dealbatum. None of the fruits examined contained mature seeds; however, the narrow areole suggests that the embryo is narrowly cylindrical.

Jussieu (1843) proposed the names Ryssopterys cumingiana and $R$. dealbatum in the same publication, but the types are conspecific. Niedenzu (1915) was the first author to choose $R$. dealbatum over $R$. cumingiana.

\section{Stigmaphyllon discolor (Gand.) C.E.Anderson, comb. nov.} - Map 7, 14

Stigmaphyllon discolor (Gand.) C.E.Anderson. - Ryssopterys discolor Gand., Bull. Soc. Bot. France 60 (1913) 458. - Ryssopterys timoriensis var. discolor (Gand.) M.Jacobs (1955). - Type: Franc 583 (holo P; iso A, E, L, NY, UC), New Caledonia, Yahoué, Nov. 1906.

Ryssopterys austrocaledonica Nied. (1915) 63. - Type: Vieillard 290 [leg. Deplanche] (holo $\mathrm{B}+$; lecto, designated here, BR; iso K, L), New Caledonia, Kanala.

Ryssopterys austrocaledonica var. primaeva Nied. (1915) 63. - Syntypes: New Caledonia, 'Gilliwray' [= MacGillvray?] s.n. (syn B†); 'Novae Hebridae' [Vanuatu] unknown collector s.n. (syn W, not located).

Ryssopterys timoriensis var. neocaledonica Baker f. (1921) 278. - Type: Compton 134 (holo BM; iso NSW), New Caledonia, Nouméa, Port Dépointes wood.

Vine [to $10 \mathrm{~m}$ ]; stems densely sericeous, the vesture sloughed off in older parts, eventually glabrous. Laminas of the larger leaves $3.5-12$ by $2-7 \mathrm{~cm}$, lanceolate to elliptical to ovate, apex apiculate to emarginate-apiculate, base truncate to shallowly cordate, adaxially densely tomentose when young but eventually glabrous or with some hairs retained on costa and secondary veins, the vesture often sloughed often in patches, abaxially tomentose, the hairs $0.2-1.2 \mathrm{~mm}$ long, straight to wavy to crisped to curled or V-shaped, sessile or subsessile or with a stalk to $0.1 \mathrm{~mm}$ long, secondary veins prominent abaxially; laminar glands $0.2-0.4 \mathrm{~mm}$ diam, borne on the margin and abaxially adjacent to the margin; petioles $1.2-7$ $\mathrm{cm}$ long, densely sericeous-tomentose, in older leaves the vesture sloughed off in patches, with a pair of glands borne at apex or partly on the base of the lamina, each gland $0.4-1$ $\mathrm{mm}$ diam, slightly prominent; stipules 1 on each side of petiole, triangular, bractlike, to $1 \mathrm{~mm}$ long, to $0.5 \mathrm{~mm}$ wide, sometimes with an additional smaller stipule, abaxially densely sericeous, sometimes hidden by stem vesture. Hermaphrodite flowers $8-15(-20)$ in each umbel or condensed pseudoraceme, borne in dichasia or sometimes solitary; peduncles 4.5-9.5 $\mathrm{mm}$ long, pedicels $3.5-10 \mathrm{~mm}$ long, both densely sericeous, peduncles $0.5-1.5(-1.7)$ times as long as pedicels; bracts $1-1.5$ by $0.5-0.7 \mathrm{~mm}$, narrowly triangular, bracteoles $0.8-1$

Map 7 Distribution of Stigmaphyllon mackeeanum C.E.Anderson $(\diamond)$, and of S. discolor (Gand.) C.E.Anderson (๑) and S. grandifolium (Guillaumin) C.E.Anderson ( $\square$ ) in New Caledonia. See Map 14 for record of S. discolor in the Solomon Islands; see Map 8 for distribution of $S$. grandifolium in Vanuatu.

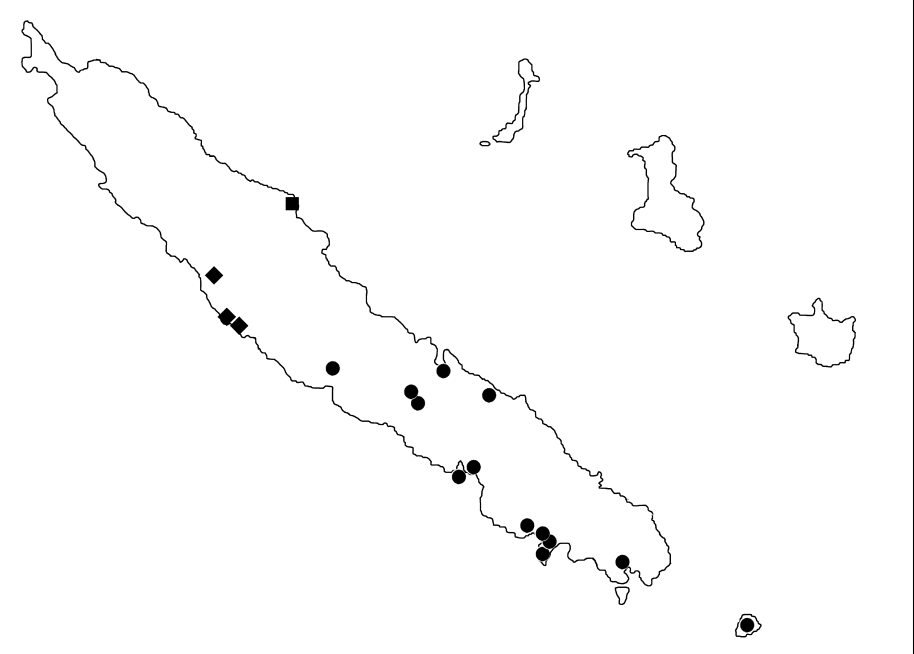


by $0.5-0.7 \mathrm{~mm}$, narrowly triangular or oblong, bracts and bracteoles abaxially sericeous to sparsely so or sometimes glabrous. Sepals $2.5-2.8$ by $2.2-3 \mathrm{~mm}$, orbicular or broadly ovate, sericeous but often glabrous along the margin. Petals yellow, claw 0.2-0.5(-1) mm long, limb 8.5-10 mm long and wide, base acute or truncate, margin subentire or shallowly erose. Stamens 12-16; filaments 2.8-3.6 mm long; anthers 1.4-1.6 mm long, without apiculum, glabrous. Ovary c. $1.8 \mathrm{~mm}$ long; styles 3.8-4 mm long, c. 0.1 diam, stigma $0.3 \mathrm{~mm}$ diam, peltate. Male flowers: filaments 2.8-3.6 mm long; anthers 1.5-1.6 mm long, without apiculum, glabrous; ovary essentially absent, a minute mound of tissue embedded in a tuft of hairs; styles 3, 4.5-4.8 mm long, c. $0.1 \mathrm{~mm}$ diam, free or 2 united in the proximal $1 / 2$, stigma $0.2-0.3 \mathrm{~mm}$ diam, peltate, rarely with a 4th style $3.5 \mathrm{~mm}$ long. Dorsal wing of samara 2.3-3 by $0.9-1.5 \mathrm{~cm}$; nut $5-5.5 \mathrm{~mm}$ long, $3.5-4 \mathrm{~mm}$ diam, broadly ovoid to spheroid, with prominent ridges, lateral winglets absent; areole 2.5-3 mm long and wide. Embryo $3.2-3.3 \mathrm{~mm}$ long, ovoid, outer cotyledon $3-3.2$ by $2-2.1 \mathrm{~mm}$, inner cotyledon $2.6-2.9$ by $1.8-2 \mathrm{~mm}$, both straight.

Distribution - New Caledonia; one collection (Brass 3400, A, BRI) from the Solomon Islands (Santa Isabel Island).

Habitat \& Phenology - Altitude from sea level to $150(-400)$ $\mathrm{m}$; in moist to dry forest or at forest edge, littoral scrub, and roadsides, reported from serpentine; collected in flower from September to April, in fruit from January to March.

Notes - Stigmaphyllon discolor is the most commonly collected species in New Caledonia. A dense vesture covers all vegetative parts, but the adaxial surface of the laminas is glabrescent to glabrous at maturity. This species differs from S. mcphersonii, the other densely tomentose species in New Caledonia, by its umbels containing $8-20$ flowers (vs 4-6) with large petals (8.5-10 mm diam vs 6-7 mm) and 12-16 (vs 10) stamens. The wing of the samara is $2.3-3 \mathrm{~cm}$ long, but only $1.7-2 \mathrm{~cm}$ long in S. mcphersonii.

The holotype of Ryssopterys austrocaledonica was at B and is no longer extant. The duplicate at BR bears Niedenzu's annotation and is here chosen as the lectotype.

\section{Stigmaphyllon grandifolium (Guillaumin) C.E.Anderson,} comb. nov. - Map 7, 8

Stigmaphyllon grandifolium (Guillaumin) C.E.Anderson. - Ryssopterys grandifolia Guillaumin, Bull. Mus. Hist. Nat. (Paris), sér. 2, 14 (1942) 286. - Type: Vieillard 2370 (lecto, designated here, P; isolecto K, P), New Caledonia, bord de la mer près Wagap.

Vine; stems densely sericeous when young, older parts glabrate to glabrous. Laminas of the larger leaves $6-14.5$ by $5-12 \mathrm{~cm}$, narrowly to broadly ovate to cordate to orbicular, apex apiculate or briefly acuminate, base truncate to cordate, adaxially and abaxially sericeous when young, soon glabrate to glabrous but often with scattered hairs on the costa, the hairs $0.4-0.7$ $\mathrm{mm}$ long, straight or sinuous, sessile, secondary veins prominent abaxially; marginal glands $0.3-0.5 \mathrm{~mm}$ diam; petioles $2-9(-10.5) \mathrm{cm}$ long, densely sericeous but glabrate in age, with a pair of glands borne at apex, each gland $0.8-1.5 \mathrm{~mm}$ diam, slightly prominent or flush; stipules $2(-3)$ on each side of petiole, leaflike, largest stipules to $20 \mathrm{~mm}$ long, to $13 \mathrm{~mm}$ wide, elliptical to suborbicular, smaller stipules to $7 \mathrm{~mm}$ long, to 2.5 $\mathrm{mm}$ wide, lanceolate to obovate, vesture like that of laminas. Hermaphrodite flowers c. 15-30 in each pseudoraceme, borne in dichasia or compound inflorescences; peduncles 5.5-15 $\mathrm{mm}$ long, pedicels $2.5-11 \mathrm{~mm}$ long, both densely sericeous, peduncles $0.4-4$ times as long as pedicels; bracts $1.5-3$ by $0.5-0.6 \mathrm{~mm}$, narrowly triangular, bracteoles $(1.3-) 1.5-3$ by $0.5-0.7 \mathrm{~mm}$, linear or oblong, bracts and bracteoles abaxially sericeous or with scattered hairs. Sepals (2.5-)3-3.7 by 2-2.8 $\mathrm{mm}$, oblong to broadly ovate, sericeous or the distal $1 / 4-1 / 3$ glabrate to glabrous. Petals yellow, claw $0.5-1(-1.5) \mathrm{mm}$ long, limb $8.5-12$ by $8-10 \mathrm{~mm}$, base acute or briefly truncate, margin subentire or shallowly erose. Stamens 10 ; filaments $2.5-3 \mathrm{~mm}$ long, anthers 1-1.2 mm long, without apiculum, glabrous. Ovary c. 1.5-2 mm long; styles c. $3 \mathrm{~mm}$ long, 0.15-0.2 mm diam, stigma c. $0.4 \mathrm{~mm}$ diam, peltate, borne at a slant. Male flowers: filaments 3.3-4 mm long, anthers $1.3-1.6 \mathrm{~mm}$ long, without apiculum, glabrous; ovary absent or rudimentary, a mound of tissue to $0.8 \mathrm{~mm}$ long embedded in a tuft of hairs; styles usually absent, sometimes the 'ovary' extended into a short beak, or rarely with $1(-3)$ rudimentary style(s) $0.05-2 \mathrm{~mm}$ long. Dorsal wing of samara $3.5-4$ by $1.4-1.8 \mathrm{~cm}$; nut $8-9 \mathrm{~mm}$ long, $4.5-5 \mathrm{~mm}$ diam, narrowly ellipsoid, with prominent ridges and 1-2 lateral winglets, winglets $1-4$ by $1-2.2 \mathrm{~mm}$, areole $6-6.5$ by $1.5-3 \mathrm{~mm}$. Embryo c. $7.2 \mathrm{~mm}$ long, narrowly ellipsoid, the cotyledons slightly unequal, $6.5-7$ by $2-2.3 \mathrm{~mm}$, straight.

Distribution - Vanuatu, New Caledonia.

Habitat \& Phenology - Altitude from sea level to $590 \mathrm{~m}$; in rain forest and secondary forest, along the seashore, and at roadsides; collected in flower throughout the year, in fruit in July.

Note - Stigmaphyllon grandifolium is the only species of the genus known from Vanuatu, the source of all but one of the collections seen; the exception is the type from New Caledonia. It is immediately separated from other species of New Caledonia by its leaflike stipules; the others have minute triangular bractlike stipules. In addition, $S$. grandifolium is distinctive in

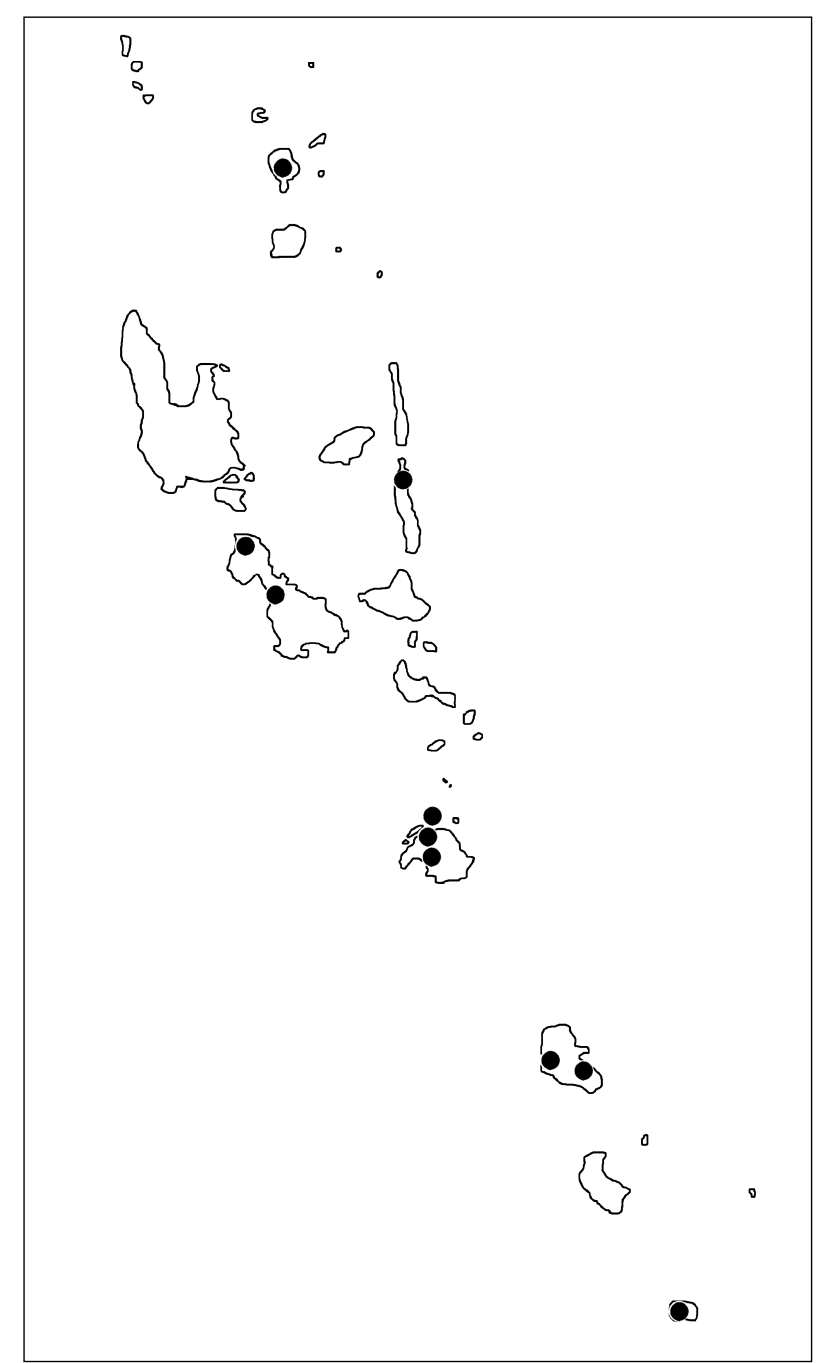

Map 8 Distribution of Stigmaphyllon grandifolium (Guillaumin) C.E.Anderson in Vanuatu (see Map 7 for record in New Caledonia). 


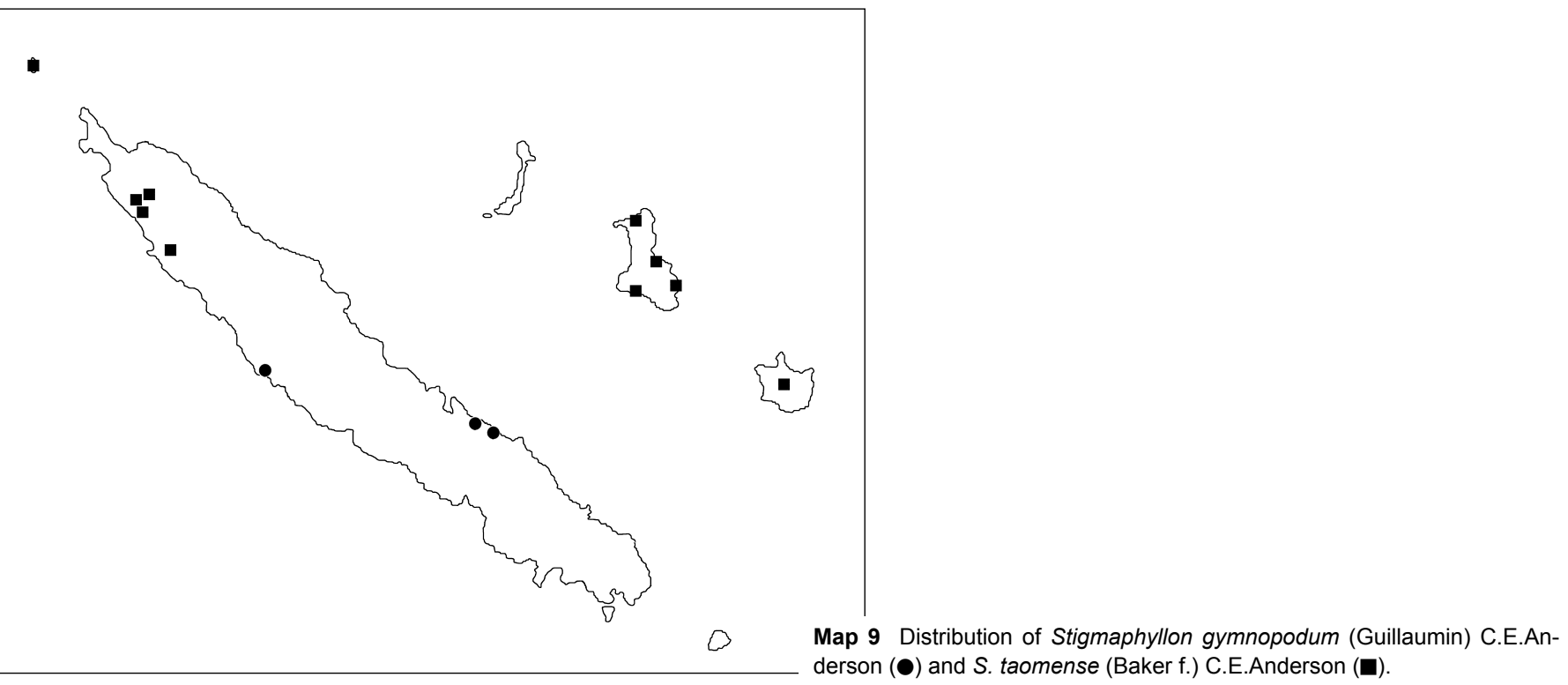

its large bracteoles (to $3 \mathrm{~mm}$ long), large petals $(8.5-12 \mathrm{~mm}$ diam), and large samaras (dorsal wing $3.5-4 \mathrm{~cm}$ long). As a rule, the male flowers lack styles; however, styles are present in one collection, Schmid $5112(\mathrm{P})$.

\section{Stigmaphyllon gymnopodum (Guillaumin) C.E.Anderson,} comb. nov. - Map 9

Stigmaphyllon gymnopodum (Guillaumin) C.E.Anderson. - Ryssopterys gymnopoda Guillaumin, Bull. Soc. Bot. France 79 (1932) 516. - Type: Balansa 3524 (holo $P$; iso $P$ ), New Caledonia, collines éruptives, près de

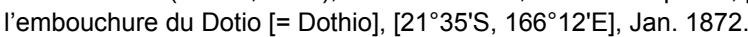

Vine; stems sericeous when young, soon glabrous. Laminas of the larger leaves $4-6.8$ by $2-3 \mathrm{~cm}$, narrowly lanceolate to elliptical or oblong, apex apiculate or emarginate-apiculate, base truncate, adaxially and abaxially with scattered hairs when young, soon glabrate to glabrous or with some hairs retained abaxially at or near the base, the hairs $0.5-1 \mathrm{~mm}$ long, terete, straight, white, sessile, secondary veins prominulous or not abaxially; marginal glands $0.3-0.4 \mathrm{~mm}$ diam or absent; petioles $1.5-2 \mathrm{~cm}$ long, densely sericeous, with a pair of glands borne at apex, each gland $0.8-1 \mathrm{~mm}$ diam, slightly prominent; stipules rudimentary, 1 on each side of petiole, triangular, bractlike, to $0.3 \mathrm{~mm}$ long and wide, glabrous, sometimes hidden by stem vesture. Hermaphrodite flowers not seen. Male flowers (5-)6 in a solitary umbel; peduncles $3.5-5 \mathrm{~mm}$ long, densely sericeous, pedicels $3.5-6(-8) \mathrm{mm}$ long, glabrous and red or the basal $1 / 4$ sericeous, peduncles $(0.4-) 0.7-1.2$ times as long as pedicels; bracts $1-1.4$ by c. $0.8 \mathrm{~mm}$, triangular, bracteoles $1-1.5$ by $0.7-0.8 \mathrm{~mm}$, triangular, bracts and bracteoles abaxially with scattered hairs. Sepals c. $2.5 \mathrm{~mm}$ long and wide, ovate, glabrous or with a few scattered hairs. Petals yellow, claw 1-1.3 $\mathrm{mm}$ long, limb $6-7$ by $5-6.5 \mathrm{~mm}$, base acute or truncate, margin subentire or shallowly erose. Stamens 10 ; filaments $2-2.2 \mathrm{~mm}$ long; anthers c. $1 \mathrm{~mm}$ long, oblong, without apiculum, glabrous. Ovary absent, or rudimentary and composed of 1-2 elongate structures, each to $1 \mathrm{~mm}$ long, embedded in a tuft of hairs. Samara not seen.

Distribution - New Caledonia.

Habitat \& Phenology - One collection (MacKee 14387) from serpentine at $100 \mathrm{~m}$; collected in flower from December to February.

Additional specimens examined. New CAledonia, Col de Nekoro, entre Nepoui et Poya, 100 m, 3 Feb. 1966, MacKee 14387 (MICH, P); basse vallée de Thio, 100 m, 21 Dec. 1966, MacKee 16105 (MICH, P).
Note - Stigmaphyllon gymnopodum is named for the glabrous, red pedicels, which immediately separate it from all others species.

\section{Stigmaphyllon intermedium (Hochr.) C.E.Anderson, comb. nov. - Map 10}

Stigmaphyllon intermedium (Hochr.) C.E.Anderson. - Ryssopterys intermedia Hochr., Bull. Inst. Bot. Buitenzorg 19 (1904) 45; PI. bogor. exsicc. 21 (1904). - Type: based on a living specimen of unknown provenance grown at the Bogor Botanical Garden; distributed as 'no. 35' (holo BO, not seen; iso $B R, K, L, N Y, P$ ).

Vine; stems sericeous when young, eventually glabrescent. Laminas of the larger leaves $5-11$ by $4-7.2 \mathrm{~cm}$, elliptical to ovate or subcordate, apex apiculate, base briefly acute to slightly cordate, adaxially glabrous, abaxially finely and evenly sericeous (appearing glabrous to the naked eye), the hairs not or barely touching, $0.1-0.5 \mathrm{~mm}$ long, straight, sessile, secondary veins prominent abaxially; marginal glands $0.3-0.5(-0.8)$ $\mathrm{mm}$ diam; petioles $2.3-3 \mathrm{~cm}$ long, densely sericeous, eventually glabrescent, with a pair of glands borne at apex, each gland 0.9-1.6 mm diam, to $0.5 \mathrm{~mm}$ high, shallowly cup-shaped or prominent; stipules 1 on each side of petiole, triangular, bractlike, $0.4-0.6(-1)$ by $0.5-0.7 \mathrm{~mm}$, sericeous abaxially. Hermaphrodite flowers not seen; styles retained on samaras c. $4 \mathrm{~mm}$ long, $0.1 \mathrm{~mm}$ diam. Male flowers c. 10-15 in each pseudoraceme or umbel, borne in dichasia; peduncles 3.2-7 $\mathrm{mm}$ long, pedicels $2.5-3.5 \mathrm{~mm}$ long, both densely sericeous, peduncles 1.1-2 times as long as pedicels; bracts $c$. 1 by c. $0.7 \mathrm{~mm}$, narrowly triangular, with scattered hairs, bracteoles $0.6-0.7$ by c. $0.4 \mathrm{~mm}$, oblong, sericeous. Sepals c. $1.5 \mathrm{~mm}$ long and wide, suborbicular, densely sericeous. Petals yellow, claw absent, limb 4.5-5 mm long and wide, base acute, margin subentire or shallowly erose. Stamens 10; filaments 2.6-2.8 mm long, anthers c. $1.5 \mathrm{~mm}$ long, without apiculum, glabrous. Ovary rudimentary, a mound of tissue up to $3 \mathrm{~mm}$ long, often drawn out into beak, embedded in a tuft of hairs; styles absent. Dorsal wing of immature samara $2-2.2$ by $0.9-1$ $\mathrm{cm}$, nut $5.5 \mathrm{~mm}$ long, $3.5 \mathrm{~mm}$ diam, probably spheroid when mature, strongly ribbed, lateral winglets absent, areole c. 3.5 by c. $3 \mathrm{~mm}$; immature embryo spheroid, with the cotyledons convoluted and folded within each other.

Notes - Stigmaphyllon intermedium is distinguished by the abaxial laminar vesture and flowers. The lower surface of the lamina appears glabrous to the naked eye but is sparsely and 


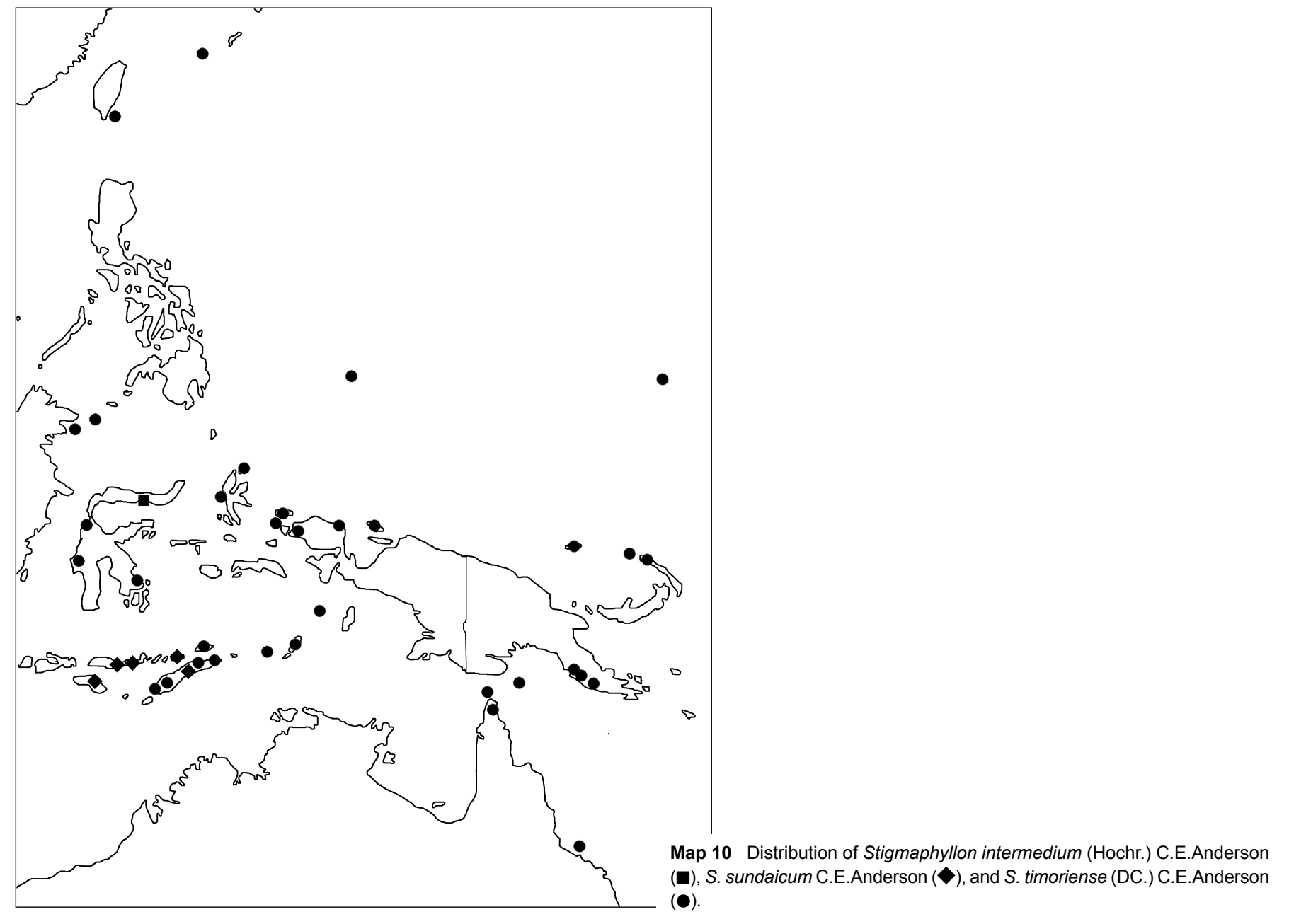

evenly sericeous; the hairs are straight, appressed, and not or barely touching. The small petals are only $4-4.5 \mathrm{~mm}$ in diameter and lack a claw.

This enigmatic species was described from plants of unknown provenance grown at the Bogor Botanical Garden. Only two other collections match the type. One is another garden specimen from the Bogor Botanical Garden, without data other than the location of the garden bed at that time ('XVII, H. 70a'; SING), and perhaps taken from the same source as the type. The other collection is Riedel s.n. (K) from Gorontola, Sulawesi; it comprises one branch with male flowers, in bud or a few open but somewhat obscured by glue, and a second branch with immature samaras. Many of the early introductions to the Bogor Botanical Garden resulted from the explorations of Teijsmann; he is known to have collected in the region of Gorontola (Van Steenis 1950), and it is possible that the plants from which the type for $S$. intermedium was prepared were brought from Sulawesi to Bogor by Teijsmann.

\section{Stigmaphyllon mackeeanum C.E.Anderson, sp. nov. — Fig. 4a-h; Map 7}

Differt a $S$. angustifolio et $S$. gymnopodo staminibus 12-14(-18), petalis 9-10 mm diametro, floribus masculinis styliferis. - Typus: MacKee 16116 (holo MICH; iso P), New Caledonia, Poya, 30 m, 24 Dec. 1966.

Etymology. The specific epithet honours Hugh Shaw MacKee (19121995), whose studies of the vegetation of New Caledonia and excellent collections greatly increased our understanding of that fascinating flora.

Vine; stems sericeous when young, soon glabrescent to eventually glabrous. Laminas of the larger leaves $4-9$ by $2.5-6 \mathrm{~cm}$, narrowly lanceolate to elliptical to broadly elliptical to ovate, apex apiculate or emarginate, base truncate to cordate, adaxially and abaxially sericeous when young but soon glabrate to glabrous and often with scattered hairs retained especially abaxially along the costa and toward the base of the lamina, the hairs $0.3-0.8 \mathrm{~mm}$ long, straight to wavy, sessile, secondary veins prominulous abaxially; marginal glands c. $0.2 \mathrm{~mm}$ diam or absent; petioles $1.5-2.5 \mathrm{~cm}$ long, densely sericeous, with a pair of glands borne near the apex, 1-1.5(-2) mm below the base of the lamina, each gland $0.5-0.8 \mathrm{~mm}$ diam, projecting up to $0.3 \mathrm{~mm}$ above the surface of the petiole; stipules 1 on each side of petiole, triangular, bractlike, 0.3-0.4 mm long and wide, sometimes with an additional smaller stipule, often hidden by the stem vesture. Hermaphrodite flowers not seen. Male flowers (6-)8-12 in each umbel, borne in dichasia or sometimes solitary; peduncles 3-8 mm long, pedicels $5.5-6.5 \mathrm{~mm}$ long, both densely sericeous, peduncles $0.4-1.2$ times as long as pedicels; bracts $1-1.2$ by $0.6-0.7 \mathrm{~mm}$, narrowly triangular, bracteoles $0.7-0.8$ by c. $0.4 \mathrm{~mm}$, oblong, bracts and bracteoles abaxially with scattered hairs. Sepals $2.5-3 \mathrm{~mm}$ long and wide, broadly ovate to suborbicular, sericeous at base but otherwise glabrous or with scattered hairs in the centre. Petals yellow, claw 1-1.5 mm long, limb 9-10 mm long and wide, base truncate, margin denticulate-erose to shallowly erose. Stamens 12-14(-18); filaments $2.5-3.5 \mathrm{~mm}$ long; anthers $1.5-1.7 \mathrm{~mm}$ long, oblong, without apiculum, glabrous. Ovary essentially absent, a minute mound of tissue embedded in a tuft of hairs or the hairs few; styles 3, 1 free and 2 united for the entire length or only in the proximal $2 / 3,3.5-3.8 \mathrm{~mm}$ long, single style c. $0.1 \mathrm{~mm}$ diam, stigma (of single style) $0.3 \mathrm{~mm}$ diam, peltate, rarely with a rudimentary 4 th style. Dorsal wing of samara 1.8-2 by $0.9-1 \mathrm{~cm}$; nut $6-6.5 \mathrm{~mm}$ long, $5-5.8 \mathrm{~mm}$ diam, spheroid, 

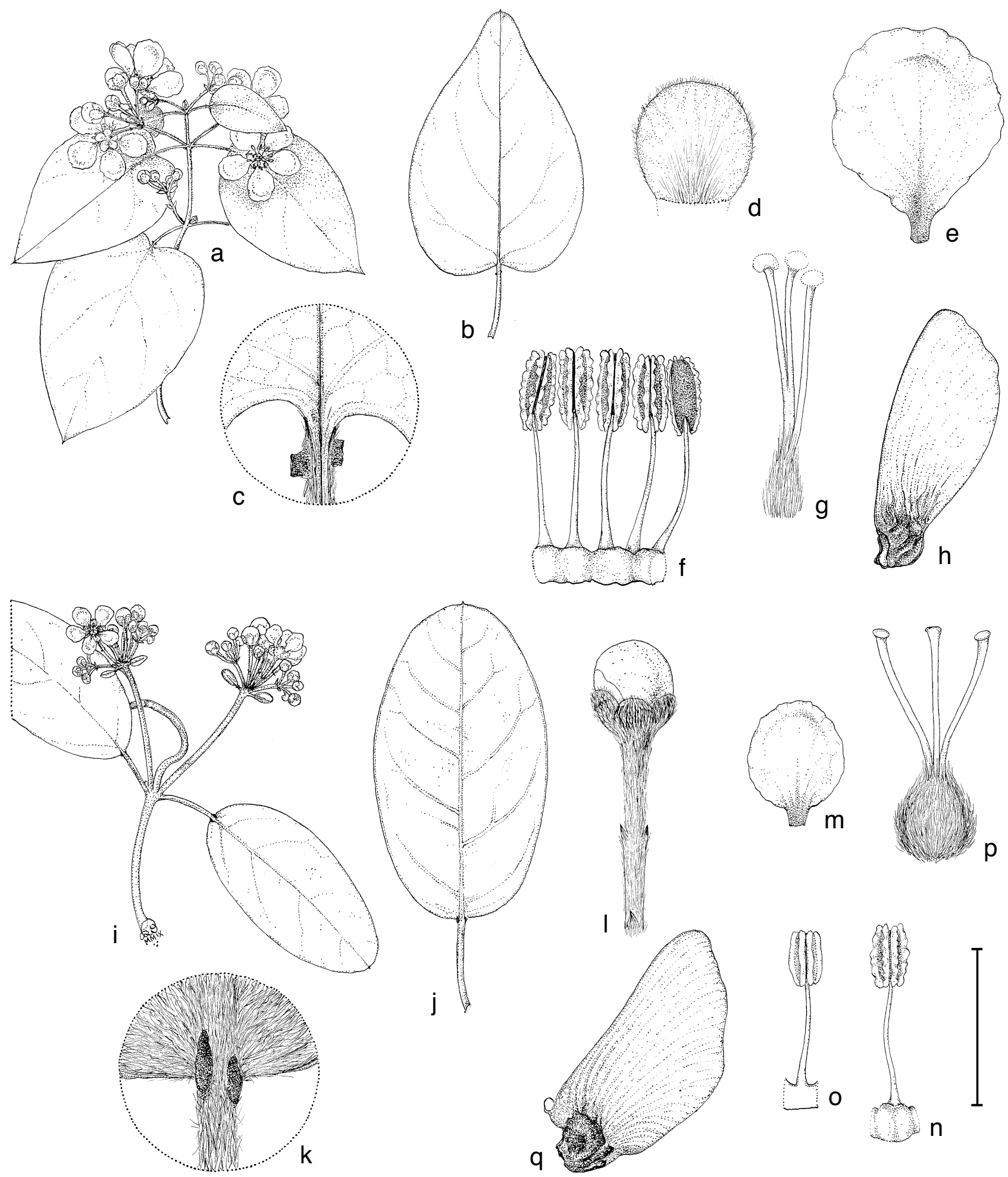

Fig. 4 Stigmaphyllon mackeeanum C.E. Anderson and S. mcphersonii C.E.Anderson. a-h: S. mackeeanum. a. Flowering branch; b. large leaf; c. base of lamina and apex of petiole bearing a pair of glands; $d$. sepal, abaxial view; e. petal - male flower: f. five stamens and g. three styles (two partly united) arising from a rudimentary ovary embedded in a tuft of hairs; h. samara. - i-q: $S$. mcphersonii. i. Flowering branch; j. large leaf; k. base of lamina with pair of glands and showing abaxial surface of lamina; I. flower bud with peduncle and pedicel; $\mathrm{m}$. petal; $\mathrm{n}$. stamen from male flower; o. stamen from hermaphrodite flower; p. gynoecium; q. samara. - Scale bars: a, b, i, j= 4 cm; c, d = 4 mm; e, l, m = 8 mm; f, g, n-p = 2.7 mm; h, q = $1.3 \mathrm{~cm} ; \mathrm{k}=5.7 \mathrm{~mm}(\mathrm{a}-\mathrm{g}$ : MacKee $16116, \mathrm{P}$; h: MacKee 30059, MICH; i-n: McPherson 4229, MO; o-q: MacKee 20167, P.)

prominently ribbed, lateral winglets absent, areole $3-3.5$ by 3.5-4 mm. Embryo c. $4 \mathrm{~mm}$ long, ovoid; outer cotyledon c. 4.5 by c. $2.5 \mathrm{~mm}$, the distal $1 / 4$ curved, inner cotyledon c. 2.5 by c. $2 \mathrm{~mm}$, straight.

Distribution - New Caledonia.

Habitat \& Phenology - Altitude from sea level to $100 \mathrm{~m}$; forest and thickets, one report from serpentine (MacKee 22995); collected in flower in December to February, once in fruit in April.
Additional specimens examined. New Caledonia, Népoui, 5 Jan. 1961 MacKee 7962 (CANB, L, US); Nepoui, presqu'île de Mueo, 0-10 m, 10 Dec. 1970, MacKee 22995 (MICH, P); Pouembout, Paouta, 150 m, 15 Feb. 1973 MacKee 26308 (MICH); Poya, Népou, 5 m, 12 Apr. 1975, MacKee 30059 $(\mathrm{MICH})$; without locality, Vieillard $706(\mathrm{P})$

Notes - Stigmaphyllon mackeeanum differs from the other species in New Caledonia with glabrous leaves and small triangular stipules by its male flowers with 12-18 stamens, petals 9-10 $\mathrm{mm}$ in diameter, and three styles. In S. angustifolium and 
S. gymnopodum the stamens number 10 , the petals are 6-7 $\mathrm{mm}$ in diameter, and the male flowers lack styles. Stigmaphyllon grandifolium also has large petals, but is immediately distinguished by its leaflike stipules.

The hermaphrodite flowers of $S$. mackeeanum are unknown, but one collection (MacKee 30059) has samaras with a short dorsal wing, only c. $2 \mathrm{~cm}$ long, that contain an ovoid embryo.

12. Stigmaphyllon mariae C.E.Anderson, sp. nov. - Fig. 5; Map 11

Differt a $S$. papuano stipulis foliosis, stylis c. $3.5 \mathrm{~mm}$ longis, $0.1 \mathrm{~mm}$ latis. - Typus: Pulsford \& Floyd 5449 (holo BRI; iso A, CANB, L, SING), Papua New Guinea, East Sepik Province, near Dagua, 19 Oct. 1953.

Etymology. This species is named for Maria Johanna van Steenis-Kruseman (1904-1999) in recognition of her prodigious bibliographical and biographic work. All students of the flora of Southeast Asia are indebted to her for her exhaustive research on publications, maps, and collectors, much of it presented in volume 1 of Flora Malesiana ('the Green Bible'; Van Steenis $1950)$ and supplements to volume 5 (Van Steenis 1956, 1958) and volume 8 (1974).

Vine; stems densely sericeous when young, older parts glabrate to glabrous. Laminas of the larger leaves $5.5-12$ by $3.5-6$ $\mathrm{cm}$, elliptical to broadly elliptical to ovate, apex apiculate, base cordate to shallowly cordate or in smaller leaves nearly truncate, adaxially very sparsely sericeous to glabrate to glabrous, abaxially sparsely but evenly sericeous, the hairs barely or not touching, $0.2-0.9 \mathrm{~mm}$ long, straight, sessile, secondary veins prominent abaxially; marginal glands $0.4-0.6 \mathrm{~mm}$ diam; petioles $1-3 \mathrm{~cm}$ long, densely sericeous, with a pair of glands borne at apex, each gland 1.2-2 mm diam, slightly prominent; stipules $2-3$ on each side of petiole, leaflike, largest stipules to $17 \mathrm{~mm}$ long, to $8 \mathrm{~mm}$ wide, elliptical to obovate, medium stipules to $5.5 \mathrm{~mm}$ long, to $2 \mathrm{~mm}$ wide, narrowly elliptical, smaller

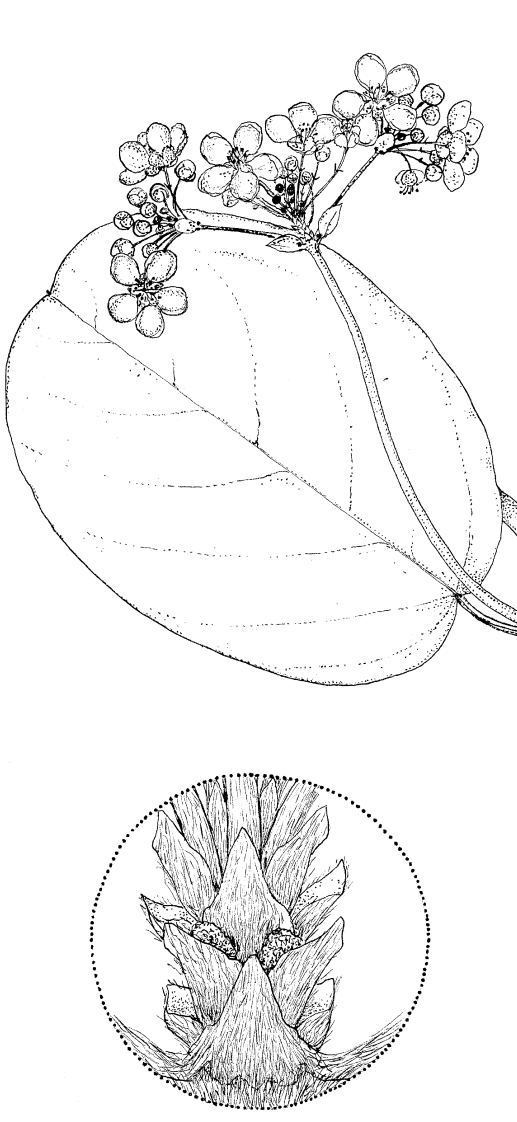

e
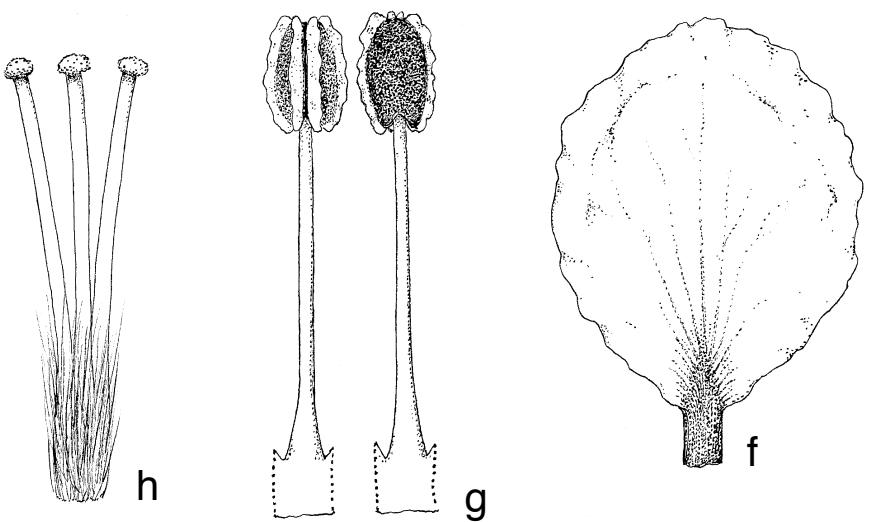

g
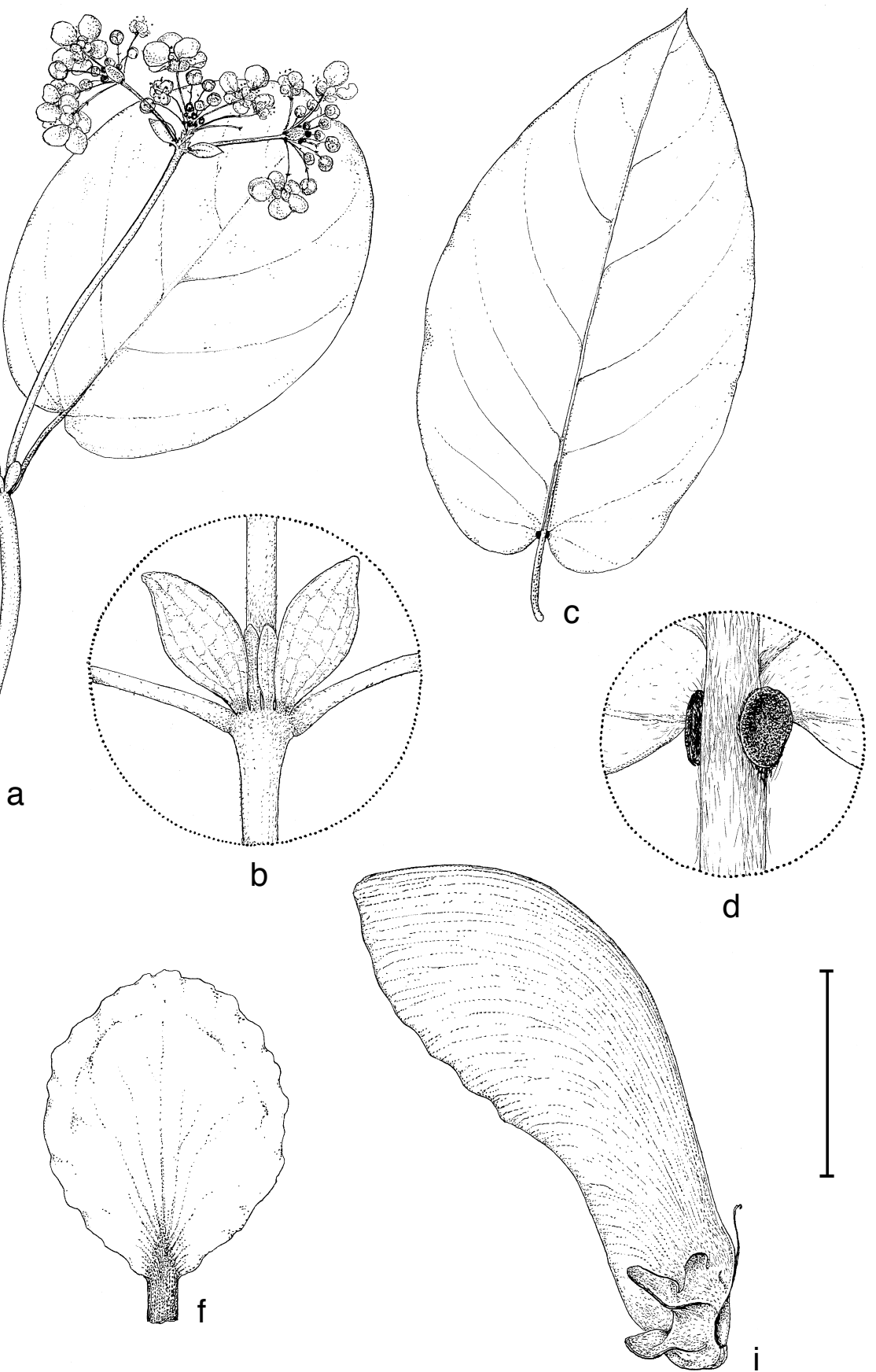

d

Fig. 5 Stigmaphyllon mariae C.E.Anderson. a. Habit; b. node with four stipules; c. leaf; d. base of lamina with pair of glands; e. detail of inflorescence, showing base of pseudoraceme with overlapping bracts; $f$. petal; $g$. two stamens of male flower; $h$. three styles arising from a rudimentary ovary embedded in a tuft of hairs (male flower); h. samara. - Scale bars: $a, c=4 \mathrm{~cm} ; \mathrm{b}=2 \mathrm{~cm} ; \mathrm{d}-\mathrm{f}=4 \mathrm{~mm} ; \mathrm{g}, \mathrm{h}=2.7 \mathrm{~mm}$; $=1.3 \mathrm{~cm}(\mathrm{a}, \mathrm{e}:$ MacKee 1930 , P; b: Iwanggin BW 5255, A; c, d, f-h: Pulsford \& Floyd 5449, CANB; i: Versteegh BW 4720, L). 


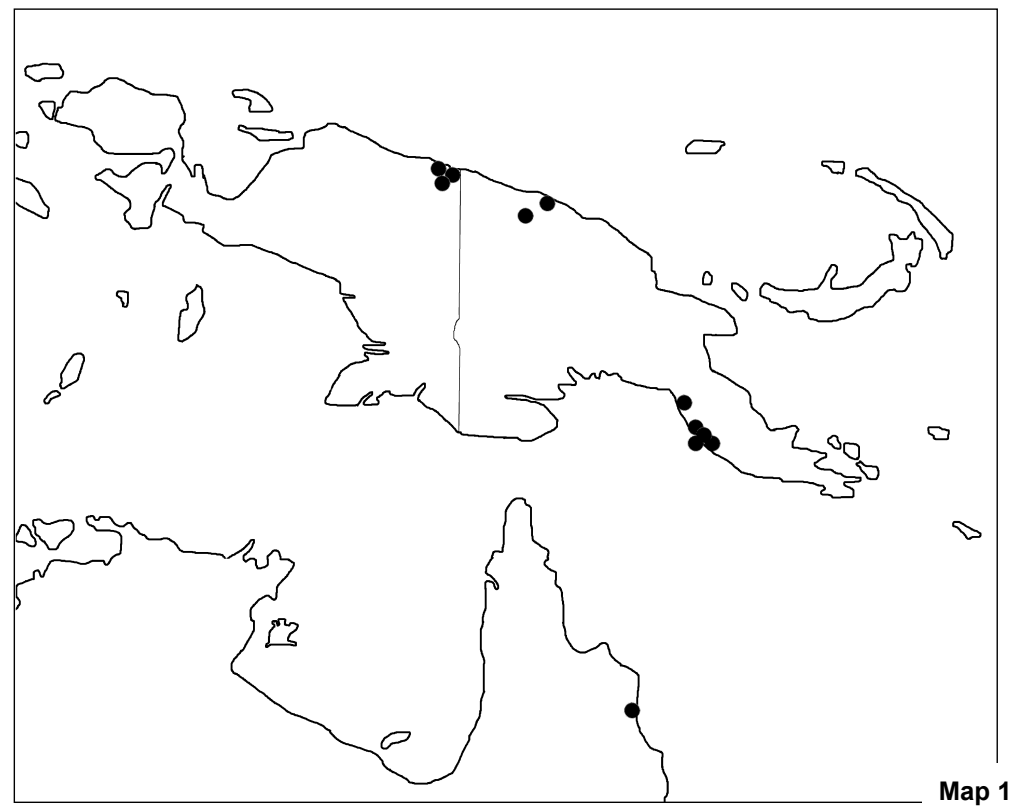

Map 11 Distribution of Stigmaphyllon mariae C.E.Anderson.

stipules to $1.6 \mathrm{~mm}$ long, to $0.6 \mathrm{~mm}$ wide, linear, vesture like that of laminas. Hermaphrodite flowers (10-)15-30 in each pseudoraceme, borne in dichasia and compound inflorescences; peduncles $2.5-9.5 \mathrm{~mm}$ long, pedicels $1.5-4 \mathrm{~mm}$ long, both densely sericeous, peduncles 1-3 times as long as pedicels; bracts $0.8-1.5$ by $0.4-0.8 \mathrm{~mm}$, narrowly triangular, bracteoles $0.8-1.2$ by $0.3-0.6 \mathrm{~mm}$, oblong, bracts and bracteoles abaxially with scattered hairs. Sepals $1.5-2$ by $1.3-1.8 \mathrm{~mm}$, ovate, sericeous or sparsely sericeous to glabrate. Petals yellow or pale yellow, claw $0.5-1 \mathrm{~mm}$ long, limb 7-7.5 mm long and wide, base truncate, margin subentire or shallowly erose. Stamens 10; filaments c. $2.5 \mathrm{~mm}$ long, anthers c. $1 \mathrm{~mm}$ long, without apiculum, glabrous. Ovary $1.3 \mathrm{~mm}$ long; styles c. $3.5 \mathrm{~mm}$ long, c. $0.1 \mathrm{~mm}$ diam, stigma $0.3-0.4 \mathrm{~mm}$ diam, peltate. Male flowers: filaments (2.5-)2.7-3.5(-3.7) mm long, anthers $1-1.2$ by c. $0.8 \mathrm{~mm}$, without apiculum, glabrous; ovary rudimentary, a mound of tissue to $0.5 \mathrm{~mm}$ long embedded in a tuft of hairs; styles absent or 3 , free or variously united, $2.5-3.5 \mathrm{~mm}$ long, $0.1 \mathrm{~mm}$ diam, stigma c. $0.2 \mathrm{~mm}$ diam, peltate. Dorsal wing of samara $3-3.5$ by $1.3-1.5 \mathrm{~cm}$; nut $7-8 \mathrm{~mm}$ long, $2.5-3.5 \mathrm{~mm}$ diam, ellipsoid, prominently ribbed, lateral winglets absent or to $4.5 \mathrm{~mm}$ long and wide, areole $6-6.5$ by $2-2.2 \mathrm{~mm}$; mature seed not seen.

Distribution - Australia (1 collection), New Guinea.

Habitat \& Phenology - Altitude from sea level to $130 \mathrm{~m}$; coastal scrub, woodlands, primary and secondary forest; collected in flower from January to September, in fruit in January, March, and April.

Additional specimens examined. Australia, Queensland, Cook Distr., Myal Beach Cape Tribulation, $16^{\circ} 07^{\prime} \mathrm{S}, 145^{\circ} 27^{\prime} \mathrm{E}, 0 \mathrm{~m}, 20$ Feb. 1982, Hinton 268 (BRI). - INDONESIA, Papua, Jayapura, Res. Hollandia, Lake Sentani (SE), 100 m, 5 Apr. 1957, Iwanggin BW 5255 (A, CANB, K, L); Hollandia (Kota Baroe), 50-100 m, 3 Jan. 1955, MacKee 1930 (K, L, P); Tami River, E of Hollandia, 16 m, 8 Aug. 1956, Schram BW 2817 (L); Div. Hollandia, Sekoli, S of Lake Sentani, 75 m, July 1961, Schram BW 9395 (A, CANB, L); Distr. Hollandia, foothills of Cycloop Mts, Kajaboe River, 130 m, 19 July 1954, Van Royen 4500 (CANB, L); Distr. Hollandia, Babrongko, S coast of Lake Sentani, 90 m, 5 Apr. 1957, Versteegh BW 4720 (CANB, L). - PAPUA NEW GuInEA, Central, Magi highway, Rigo road, SE of Manugoro, 11 Apr. 1981, Frodin UPNG 1954 (L); Port Moresby S.D., Motupore Island, Bootless Inlet, 30-31 Mar. 1974, Frodin UPNG 4263 (K, L); Tavai Creek-Rigo area, c. $46 \mathrm{mi}$ SE of Port Moresby, $200 \mathrm{ft}, 30$ Apr. 1967, Pullen 6855 (CANB, L); $1 \mathrm{~km}$ before Gabagaba turnoff, Kwikila Distr., 9 Apr. 1981, Vinas \& Naoni UPNG 7631 (L); Fairfax Harbor, $09^{\circ} 25^{\prime} S, 147^{\circ} 05^{\prime} E$, sea level, 6 Apr. 1965, Womersley NGF 19471 (A, CANB, L). East Sepik, Malu am Sepik, Ledermann 10663 (NY). Gulf, lokea, Brown 79 (A). National Capital, Port Moresby, 11 Apr. 1935, Carr 11816 (A, CANB, K, L, SING); Port Moresby, 11 Apr. 1935, Carr
11817 (CANB, K, L, NY, SING); eastern footslopes of Tovobada Hills, $12 \mathrm{mi}$ $\mathrm{N}$ of Port Moresby, 22 May 1965, Heyligers 1258 (A, CANB, L); Motupore Island, 3 Sept. 1972, Tippett UNPG 825 (L).

Notes - Stigmaphyllon mariae, a species of lowland and coastal vegetation of New Guinea, is distinguished by the sparsely sericeous but evenly distributed vesture on the abaxial surface of the leaves. It might be confused with S. papuanum, which also has sparsely sericeous leaves but differs in its bractlike triangular stipules and the short stout styles of hermaphrodite flowers; the peduncles are 2.9-5.3 times as long as the pedicels (vs 1-3 times as long in S. mariae).

The calyx in the collection Tippett UNPG 825 is one of two collections seen in which some of the sepals bear a rudimentary commissural gland (see Morphology above).

\section{Stigmaphyllon mcphersonii C.E.Anderson, sp. nov. - Fig. 4i-q; Map 3}

Differt a $S$. discolori umbellis floribus $4-6$, petalis 6-7 mm longis, staminibus 10. - Typus: McPherson 4229 (holo MICH; iso BRI, L, MO, NSW), New Caledonia, along Tontouta River and its tributary, the Kalouéhola, 10-15 m, 20 Oct. 1981

Etymology. This species is named in honour of Gordon D. McPherson (b. 1947), astute student of the flora of New Caledonia and exemplary collector.

Vine [to over $5 \mathrm{~m}$ ]; stems densely sericeous, eventually becoming glabrate to glabrous and lenticellate. Laminas of the larger leaves $4-9$ by $2-5.5 \mathrm{~cm}$, oblong to elliptical or narrowly ovate, obtuse-apiculate, base truncate or very shallowly cordate, adaxially tomentose when young and eventually glabrate to glabrous, abaxially densely tomentose, in larger leaves the vesture becoming less dense and the epidermis then evident, the hairs $0.2-1.3 \mathrm{~mm}$ long, wavy to crisped and curled, subsessile or with a stalk to $0.1 \mathrm{~mm}$ long, secondary veins prominent abaxially; marginal glands $0.4-0.5 \mathrm{~mm}$ diam; petioles $1-3 \mathrm{~cm}$ long, densely sericeous, with a pair of glands borne at apex or partly on the base of the lamina, each gland 1-1.5(-2) $\mathrm{mm}$ diam, slightly prominent, sometimes with $1(-2)$ additional smaller glands; stipules 1 on each side of petiole, rudimentary, triangular, bractlike, $0.1-0.2 \mathrm{~mm}$ long and wide, often hidden by the dense stem vesture. Hermaphrodite flowers 4-6 in each umbel, solitary or borne in dichasia; peduncles 3-7 mm long, pedicels $3-6.5 \mathrm{~mm}$ long, both densely sericeous, peduncles $0.5-1.2$ times as long as pedicels; bracts $0.5-1.2$ by $0.4-0.6$ $\mathrm{mm}$, triangular, bracteoles $0.5-1.2$ by $0.4-0.6 \mathrm{~mm}$, triangular, 
bracts and bracteoles abaxially with scattered hairs. Sepals $1.5-2 \mathrm{~mm}$ long and wide, broadly ovate, densely sericeous. Petals yellow, claw 0.8-1 mm long, limb 6-7 mm long and wide, base acute, margin shallowly erose. Stamens 10; filaments $1.5(-2) \mathrm{mm}$ long, anthers $0.9-1 \mathrm{~mm}$ long, without apiculum, glabrous. Ovary c. $1.5 \mathrm{~mm}$ long; styles $2.3-2.5 \mathrm{~mm}$ long, c. $0.1 \mathrm{~mm}$ diam, stigma $0.2-0.3 \mathrm{~mm}$ diam, peltate. Male flowers: filaments 2-2.5 mm long, anthers $1-1.2 \mathrm{~mm}$ long, without apiculum, glabrous; ovary absent or rudimentary, a mound of tissue up to $0.7 \mathrm{~mm}$ long embedded in a tuft of hairs; styles absent or rarely 1 , rudimentary and hairlike, $1.3 \mathrm{~mm}$ long, without stigma. Dorsal wing of samara $1.7-2$ by $0.8-1 \mathrm{~cm}$; nut 5-5.5 mm long, c. $4.5 \mathrm{~mm}$ diam, spheroid, with prominent ridges, lateral winglets absent, areole c. $3 \mathrm{~mm}$ long and wide. Embryo c. $4.5 \mathrm{~mm}$ long, ellipsoid, outer cotyledon c. 4 by c. 3 $\mathrm{mm}$, inner cotyledon c. 3.2 by c. $2.8 \mathrm{~mm}$, both straight but the outer cotyledon curved up at the tip.

Distribution - New Caledonia.

Habitat \& Phenology - Altitude from sea level to $600 \mathrm{~m}$; in thickets and scrub, reported from serpentine; collected in flower from October to March, in fruit in February.

Additional specimens examined. New Caledonia, Bord de la Tontouta, juste avant la mine Liliane, 1965, Blanchon 1295 (P); Tontouta, Col de Mô, 400 m, 22 Jan. 1969, MacKee 20167 (MICH, P); vallée de la Tontouta près de la mine Liliane, 100 m, 9 Mar. 1973, MacKee 26381 (MICH); Basse Tontouta, 100 m, 24 Feb. 1976, MacKee 30743 (MICH); upper Tontouta Valley, 500-600 m, 20 Nov. 1955, MacKee 3482 (A, E, L, UC).

Note - Stigmaphyllon mcphersonii is readily distinguished from $S$. discolor, the other abundantly tomentose species of New Caledonia, by its small flowers borne in 4-6-flowered umbels; the petals are 4-6 $\mathrm{mm}$ in diameter, and the stamens number 10 . The dorsal wing of the samara is $1.7-2 \mathrm{~cm}$ long. Stigmaphyllon discolor bears 8-20-flowered umbels of flowers with petals $8.5-10 \mathrm{~mm}$ in diameter and $12-16$ stamens; the dorsal wing of the samara is $2.3-3 \mathrm{~cm}$ long.

\section{Stigmaphyllon merrillii C.E.Anderson, sp. nov. - Map 6}

Differt a $S$. dealbato et $S$. timoriensi foliis abaxaliter tomentosis, antheris glabris, stylis 1.5-2 mm longis. - Type: Merrill 8247 (holo US; iso L), The Philippines, Mindanao, Distr. of Zamboanga, Nov.-Dec. 1911.

Etymology. This species is named in honour of Elmer Drew Merrill (1876-1956), a foremost student of the Philippine flora.

Vine; stems sericeous when young, eventually glabrous. Laminas of the larger leaves $7-13.5$ by $5-9.7 \mathrm{~cm}$, ovate to suborbicular, apex apiculate, base cordate, adaxially tomentulose when young, glabrescent to glabrate, eventually glabrous or with a few scattered hairs, abaxially tomentose, the hairs sessile to subsessile or T-shaped with a stalk $0.1-0.2 \mathrm{~mm}$ long, trabecula 0.3-1 mm long, crisped to curled, secondary veins prominent and tertiary veins prominulous abaxially; marginal glands $0.5-1$ $\mathrm{mm}$ diam; petioles $1.5-3.8 \mathrm{~cm}$ long, densely sericeous, with a pair of glands borne at apex, each gland $1.5-2.5 \mathrm{~mm}$ diam, prominent; stipules 2 on each side of petiole, leaflike, larger stipules to $5 \mathrm{~mm}$ long, to $2.5 \mathrm{~mm}$ wide, strap-shaped, smaller stipules to $1.8 \mathrm{~mm}$ long, to $0.5 \mathrm{~mm}$ wide, linear, sericeous abaxially. Hermaphrodite flowers $15-30(-40)$ in each pseudoraceme, borne in dichasia and compound inflorescences; peduncles 4-7.5 mm long, pedicels 3-7 mm long, both densely sericeous, peduncles $1-1.5$ times as long as pedicels; bracts $1-1.5$ by $0.5-0.8 \mathrm{~mm}$, narrowly triangular, bracteoles $0.7-1$ by $0.4-0.5 \mathrm{~mm}$, oblong, bracts and bracteoles abaxially with scattered hairs. Sepals c. $2 \mathrm{~mm}$ long and wide, broadly ovate, sericeous. Petals yellow, claw $0.3-0.8 \mathrm{~mm}$ long, limb c. $7 \mathrm{~mm}$ long and wide, base truncate or briefly acute, margin subentire or shallowly erose. Stamens 10; filaments $1.7-2 \mathrm{~mm}$ long; anthers $0.8-1 \mathrm{~mm}$ long, without apiculum, glabrous. Ovary $1-1.7 \mathrm{~mm}$ long; styles 1.5-2 mm long, c. $0.1 \mathrm{~mm}$ diam, stigma 0.3-0.4 $\mathrm{mm}$ diam, peltate. Male flowers: filaments $1.8-2.2 \mathrm{~mm}$ long, anthers $0.8-0.9 \mathrm{~mm}$ long, without apiculum, glabrous; ovary rudimentary, a mound of tissue to $0.4 \mathrm{~mm}$ long embedded in a tuft of hairs, styles absent. Dorsal wing of samara 3-3.5 by $1.3-1.5 \mathrm{~cm}$; nut c. $7.5 \mathrm{~mm}$ long, c. $4 \mathrm{~mm}$ diam, narrowly ovoid, with prominent ridges, lateral winglets absent, areole c. 4 by c. $2 \mathrm{~mm}$; mature seed not seen.

Distribution - The Philippines.

Habitat \& Phenology - Only one elevation record (c. 600 m; Ramos BS 42573); in thickets, one collection (Madulid et al. PPI 11582) reported from limestone cliff faces; collected in flower in March/April, July, September to November/December, in fruit in September.

Additional specimens examined. The PhILIPPINES, Bohol, 1841, Cuming 1845 (E, K, L, P); Coron Island, Palawan Prov., E of Cayangan Cove towards Lima Point, 8 Oct. 1993, Madulid et al. PPI 11582 (L); Mindanao, Distr. of Zamboanga, Nov.-Dec. 1911, Merrill 8117 (E, P, US); Mindanao, Davao Prov., Sept. 1922, Merrill 11617 (A, BRI, UC); Bohol, Valencia, 2000 ft, 1 Oct. 1923, Ramos BS 42573 (A, K, L, SING, UC, US); Basilan, Sept. 1912, Reillo PNH 16345 (K, P); Luzon, Bontoc Subprov., July 1913, Vanoverbergh $3725(\mathrm{P})$.

Notes - The dense tomentose abaxial laminar vesture immediately separates $S$. merrillii from the other two species of subg. Ryssopterys that occur in the Philippines, in which the mature laminas are abaxially glabrous or glabrescent. In addition, $S$. dealbatum and $S$. timoriense usually have pubescent anthers, and in hermaphrodite flowers the styles are 3.2-4 mm long (vs 1.5-2 mm long in S. merrillii). Stigmaphyllon merrillii is the only species of subg. Ryssopterys in which the laminar pubescence includes T-shaped hairs with a well-defined stalk; such hairs are commonly found in species of subg. Stigmaphyllon.

Although this taxon was recognized as a Philippine species in the past, it lacked a validly published name, and thus the name S. merrillii is here proposed. Jussieu (1843) assigned Cuming 1845 , collected on the island of Bohol, to the same species that Blume had described as Heteropterys albida from Java. As was often the custom in his day when transferring a species to a different genus, Jussieu chose a new specific epithet, and published the name Ryssopterys microstema, thus creating a superfluous name for Heteropterys albida, which he cited in synonymy. Niedenzu (1915) realized that Cuming 1845 did not represent Blume's Javan species and listed Cuming 1845 as the only representative of $R$. microstema. Merrill (1923) agreed with Niedenzu's taxonomy but, to avoid using a superfluous name, published the combination $R$. albida. In his treatment of the Malpighiaceae for Das Pflanzenreich Niedenzu (1928) followed Merrill and placed Cuming 1845 in R. albida; he maintained the Javan species in R. tiliifolia. Stigmaphyllon albidum differs from S. merrillii in its bractlike triangular stipules; it lacks the T-shaped hairs, and, especially in Java, bears a pronounced apiculum on the anthers. The peduncles are 1.3-4 times as long as the pedicels in $S$. albidum vs $1-1.5$ times as long in $S$. merrillii.

\section{Stigmaphyllon micranthum C.E.Anderson, sp. nov.} — Fig. 6I-u; Map 12

Differt a $S$. brassii stipulis bracteatis, sepalis $1.1-1.5 \mathrm{~mm}$ longis, stylis c. $1 \mathrm{~mm}$ longis. - Typus: Millar NGF 23259 (holo A; iso CANB, K, L), Papua New Guinea, Morobe Prov., Bupu village above Wampit, 2500 ft, 3 Mar. 1964.

Vine; stems densely sericeous, becoming glabrate to glabrous in age. Laminas of the larger leaves $5.2-14$ by $3.5-9 \mathrm{~cm}$, lanceolate to elliptical to ovate or suborbicular, apiculate to acuminate, truncate to cordate, adaxially glabrous but with scattered hairs on the costa and secondary veins especially toward the base, abaxially sericeous, densely so in younger 


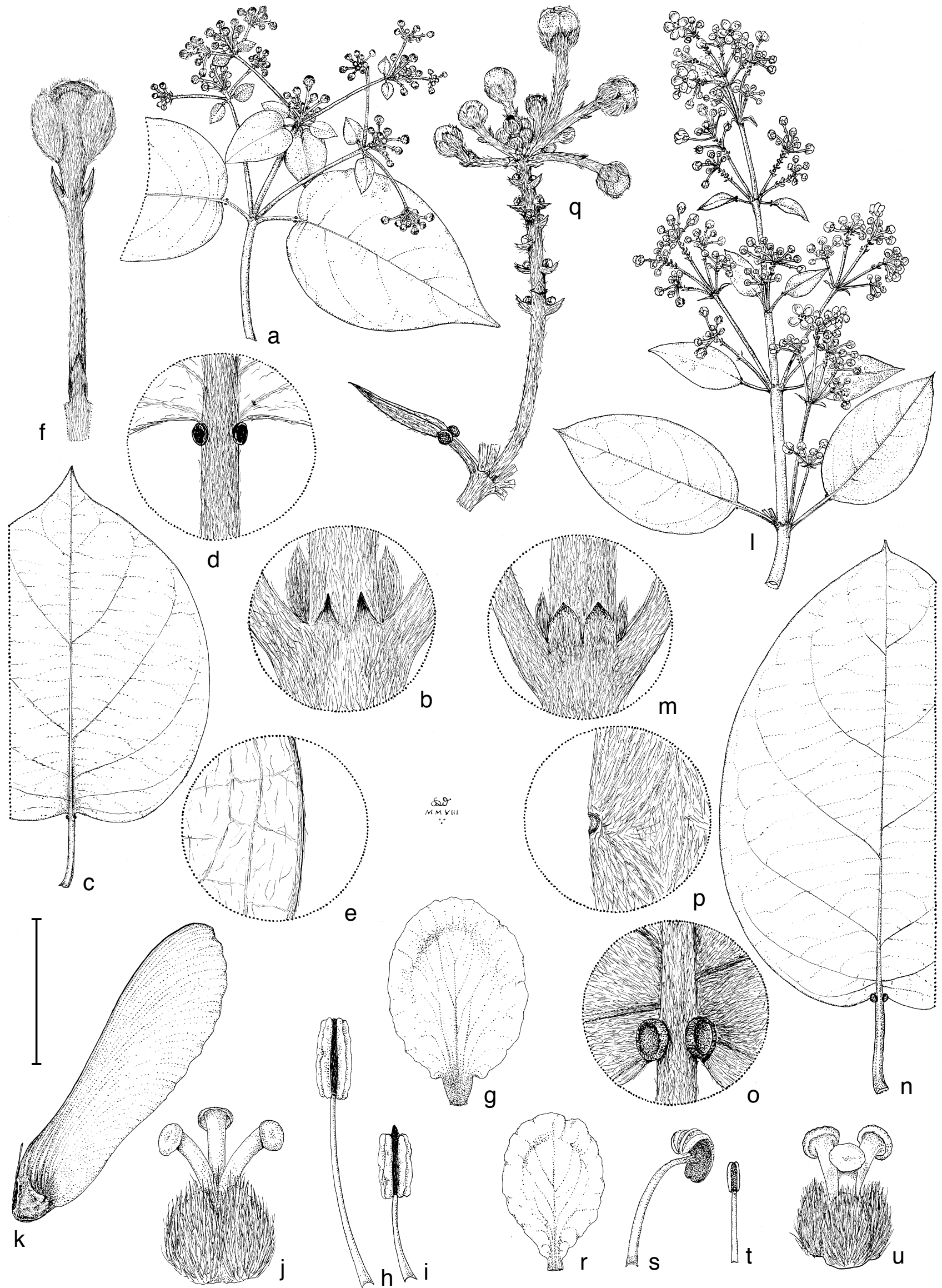

Fig. 6 Stigmaphyllon papuanum C.E.Anderson and S. micranthum C.E.Anderson. a-k: S. papuanum. a. Flowering branch; b. node with triangular stipules; c. large leaf; $d$. base of lamina with pair of glands; e. detail showing abaxial surface of lamina and margin; f. flower bud with peduncle and pedicel; g. petal; h. stamen from male flower; i. stamen from hermaphrodite flower; j. gynoecium; k. samara. - I-u: S. micranthum. I. Flowering branch; m. node with triangular stipules; n. large leaf; o. base of lamina with pair of glands; $p$. detail showing abaxial surface of lamina and marginal gland; $q$. inflorescence axis; r. petal; s. stamen from male flower; t. stamen from hermaphrodite flower; $\mathrm{u}$. gynoecium. - Scale bars: $\mathrm{a}, \mathrm{c}, \mathrm{l}, \mathrm{n}=4 \mathrm{~cm} ; \mathrm{b}, \mathrm{e}, \mathrm{f}, \mathrm{m}, \mathrm{p}=4 \mathrm{~mm} ; \mathrm{d}, \mathrm{o}, \mathrm{q}=8 \mathrm{~mm} ; \mathrm{g}, \mathrm{r}=5.7 \mathrm{~mm} ; \mathrm{h}-\mathrm{j}$, s-u =2 mm; $\mathrm{k}=$ 2 cm; (a, c-f, i, j: Millar NGF 18826, NSW; b, g, h: Womersley NGF 24921, K; k: Womersley NGF 24929, NSW; I, n-q: Millar NGF 23259, K; m, r, s: Stevens LAE 54802, A; t, u: Carr 15589, NY). 


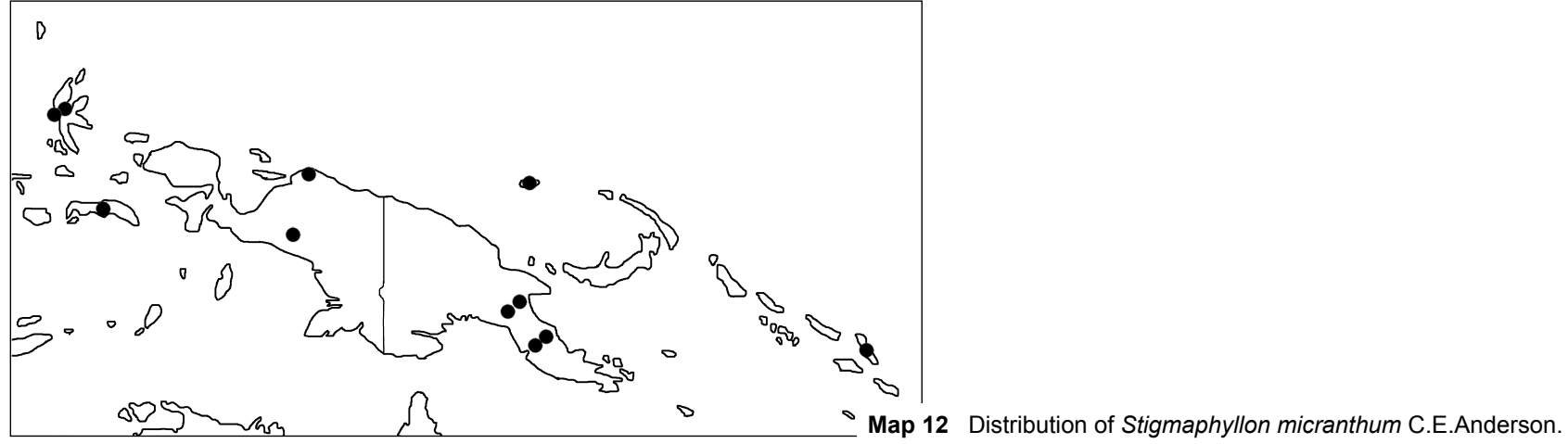

and smaller leaves and then the epidermis hidden, the hairs $0.5-0.7 \mathrm{~mm}$ long, sinuous or straight, sessile or subsessile, secondary veins prominent abaxially; marginal glands $0.3-0.5$ $\mathrm{mm}$ diam; petioles $1.5-3 \mathrm{~cm}$ long, densely sericeous to sparsely sericeous in the largest leaves, with a pair of glands borne at or near the apex, each gland $1-1.5 \mathrm{~mm}$ diam, shallowly cupshaped, the edges always raised; stipules 1 on each side of petiole, triangular, bractlike, $1.2-1.5$ by $1-1.5 \mathrm{~mm}$, adaxially sericeous but glabrous along the margin, abaxially densely sericeous to glabrescent. Hermaphrodite flowers c. 15-30 in each pseudoraceme, borne in slender compound inflorescences; peduncles $1.5-5 \mathrm{~mm}$ long, pedicels $2-5.5 \mathrm{~mm}$ long, both densely sericeous, peduncles $0.7-2(-2.7)$ times as long as pedicels; bracts $0.7-1.6$ by $0.3-0.7 \mathrm{~mm}$, narrowly triangular, bracteoles $0.5-1$ by $0.3-0.5 \mathrm{~mm}$, linear, bracts and bracteoles abaxially with scattered hairs. Sepals 1.1-1.5 by 1-1.3 mm, ovate, densely sericeous but often glabrous near the apex. Petals yellow, claw 0.5-0.7 mm long, limb 4-6 mm long and wide, base briefly truncate, margin shallowly erose. Stamens 10; filaments $1-1.2 \mathrm{~mm}$ long, anthers c. $0.5 \mathrm{~mm}$ long, without apiculum, glabrous. Ovary c. $1.1 \mathrm{~mm}$ long; styles c. 1 $\mathrm{mm}$ long, c. $0.2 \mathrm{~mm}$ diam, stigma $0.3-0.5 \mathrm{~mm}$ diam, peltate. Male flowers: filaments $1.4-2 \mathrm{~mm}$ long, anthers $0.7-0.8 \mathrm{~mm}$ long, without apiculum, glabrous; ovary rudimentary, a mound of tissue $0.3-0.5 \mathrm{~mm}$ long embedded in a tuft of hairs, styles absent. Samara not seen.

Distribution - Indonesia (Halmahera and Ternate, Papua, Seram, Sulawesi), Papua New Guinea, Solomon Islands.

Habitat \& Phenology — Altitude from sea level to $1500 \mathrm{~m}$; in forest, secondary growth, and along roadsides; collected in flower from September to March.

Additional specimens examined. INDONESIA, Halmahera, $20 \mathrm{~km}$ E of Dodinga, Darco/Modul logging camp, $00^{\circ} 30^{\prime} \mathrm{N}, 125^{\circ} 30^{\prime} \mathrm{E}, 600 \mathrm{~m}, 9$ Sept. 1985, Sidiyasa et al. TCW 3618 (L). Papua, Nassau Mts, 1000 m, Oct. 1926, Docters van Leeuwen 10749 (L); Sorong, Aifat River valley, near Sururem, 550 m, 23 Oct. 1961, Van Royen \& Sleumer, H. 6934 (A, CANB, L). Seram, Manusela NP, low hill N of Kanikeh, Kecamatan (District) Seram Utara, $03^{\circ} 06^{\prime} \mathrm{S}, 129^{\circ} 28^{\prime} \mathrm{E}, 600 \mathrm{~m}, 4$ Jan. 1985, Kato et al. C-3090 (A, L). Sulawesi, Manusela NP, trail between Kanikeh and Selumena, Kecamatan Distr., Seram Utara, $03^{\circ} 06-07^{\prime} S, 1^{\circ} 9^{\circ} 29-32 ' E, 620-820$ m, 8 Jan. 1985 , Kato et al. C-3351 (L); W Tana, 0-100 m, 9 Feb. 1919, Rutten 2052 (L). Ternate, Foramadiahi, 650 m, 14 Jan. 1921, Béguin 1319 (L). - PAPUA NEW GuineA, Central, Boridi, 4000 ft, 19 Nov. 1935, Carr 13409 (CANB, K, L, SING); Menari, 5000 ft, Feb. 1923, Lane Poole 421 (BRI, K). Madang, Kaiser-Wilhelmsland, Rani Gebirge, 1000 m, 27 Dec. 1907, Schlechter 17055 (A, BRI, C, K, L, MO). Manus, Mt Dremsel, Lorengau Subprovince, $02^{\circ} 09^{\prime} \mathrm{S}, 146^{\circ} 56^{\prime} 30 " \mathrm{E}, 300-320$ m, 26 Mar. 1981, Kerenga et al. LAE 77525 (A, BRI, E). Morobe, Menyama Subdistr., gorge c. $7 \mathrm{~km} \mathrm{~W}$ of Aseki, $07^{\circ} 20^{\prime} \mathrm{S}$, $146^{\circ} 10^{\prime} \mathrm{W}, 1130 \mathrm{~m}, 9$ Jan. 1972, Stevens LAE 54802 (A, BRI, CANB, L, NSW, SING); Kipu, $07^{\circ} 50^{\prime} S, 147^{\circ} 10^{\prime} E, 2800 \mathrm{ft}, 8$ Jan. 1966, Streimann \& Kairo NGF 26135 (CANB, L). Northern, Isuarava, 3500 ft, 15 Feb. 1936, Carr 15589 (CANB, L, NY, SING); Kokoda, 1200 ft, 20 Mar. 1936, Carr 16169 (CANB, K, L, NY); Kokoda, 1200 ft, 21 Mar. 1936, Carr 16181 (CANB, K, SING). - Solomon IsLANDS, Central Malaita, Are Are Distr., Mota, 5 mi from Kiu on west coast, $1100 \mathrm{ft}, 13$ Dec. 1963, Whitmore BSIP 3897 (K, L, SING).
Note - Stigmaphyllon micranthum is easily recognized by its very small flowers, which are aggregated into pseudoracemes that are borne in large delicate compound inflorescences. The only other species with such small flowers and bractlike triangular stipules is $S$. intermedium, in which the laminas are abaxially finely and sparsely sericeous and appear glabrous to the naked eye. In S. micranthum the laminas are so densely sericeous that the epidermis is often obscured.

\section{Stigmaphyllon papuanum C.E.Anderson, sp. nov. - Fig. 6a-k; Map 13}

Differt a $S$. mariae stipulis bracteatis, stylis $1.2-1.5 \mathrm{~mm}$ longis, $0.2 \mathrm{~mm}$ diametro. - Typus: Womersley NGF 24921 (holo BRI; iso A, CANB, K, L), Papua New Guinea, Eastern Highlands, Okasa, $10 \mathrm{mi}$ SW of Okapa, $06^{\circ} 35^{\prime} \mathrm{S}$, 145²0'E, $4700 \mathrm{ft}, 17$ May 1967.

Vine [to $6 \mathrm{~m}$ ]; stems densely sericeous when young, eventually glabrous, the vesture often sloughed off in patches. Laminas of the larger leaves $5-16$ by $3-10 \mathrm{~cm}$, elliptical to ovate or broadly ovate or suborbicular, apex acuminate, base truncate in smaller laminas and cordate in larger ones, adaxially sericeous when young, becoming sparsely so and eventually glabrescent to glabrous, abaxially sparsely sericeous (the largest laminas eventually glabrate), the hairs $0.3-0.8 \mathrm{~mm}$ long, straight to wavy, sessile, secondary veins prominent and tertiary veins prominulous abaxially; marginal glands $0.3-0.4 \mathrm{~mm}$ diam or absent; petioles $1.8-6.5 \mathrm{~cm}$ long, densely sericeous, the vesture partly abraded in older leaves, with a pair of glands borne at apex, each gland 1-2 mm diam, prominent; stipules 1 on each side of petiole, triangular, bractlike, $0.5-1.5$ by $0.4-1$ $\mathrm{mm}$, glabrous or with scattered hairs abaxially. Hermaphrodite flowers (12-)15-20 in each umbel or pseudoraceme, borne in dichasia or compound inflorescences; peduncles $4-7.5 \mathrm{~mm}$ long, pedicels $1.2-3.5 \mathrm{~mm}$ long, both densely sericeous, peduncles (1.1-)2.9-5.3 times as long as pedicels; bracts $0.8-2$ by $0.4-0.6 \mathrm{~mm}$, narrowly triangular, bracteoles $0.9-1.5$ by $0.3-0.4 \mathrm{~mm}$, oblong, bracts and bracteoles abaxially densely to sparsely sericeous. Sepals c. 2 by $1.8-2 \mathrm{~mm}$, ovate or broadly oblong, sericeous or sparsely so abaxially. Petals yellow, claw $0.5-0.8 \mathrm{~mm}$ long, limb $7.5-8 \mathrm{~mm}$ long and wide, base truncate, margin shallowly erose. Stamens 10; filaments $1.2-1.3 \mathrm{~mm}$ long, anthers $1-1.1 \mathrm{~mm}$ long including a tiny apiculum to $0.1 \mathrm{~mm}$ long, glabrous. Ovary $1.7 \mathrm{~mm}$ long, styles $1.2-1.5 \mathrm{~mm}$ long, 0.2 $\mathrm{mm}$ diam, stigma $0.5 \mathrm{~mm}$ diam, peltate. Male flowers: filaments (1.6-)2-2.5(-2.7) mm long, anthers 1.1-1.2 mm long, without apiculum, glabrous; ovary absent or rudimentary, a mound of tissue to c. $0.4 \mathrm{~mm}$ long, receptacle glabrous, styles absent. Dorsal wing of samara $3.5-4.5$ by $1.3-1.5 \mathrm{~cm}$; nut $8.5-9 \mathrm{~mm}$ long, 5.6-6 mm diam, ellipsoid, with prominent ridges, lateral winglets absent, areole c. 4 by c. $3 \mathrm{~mm}$. Embryo c. $8 \mathrm{~mm}$ long, narrowly cylindrical, outer cotyledon c. $7 \mathrm{~mm}$ long, inner cotyledon c. $4.5 \mathrm{~mm}$ long, both straight.

Distribution - Papua New Guinea (Central, Eastern Highlands, Morobe). 


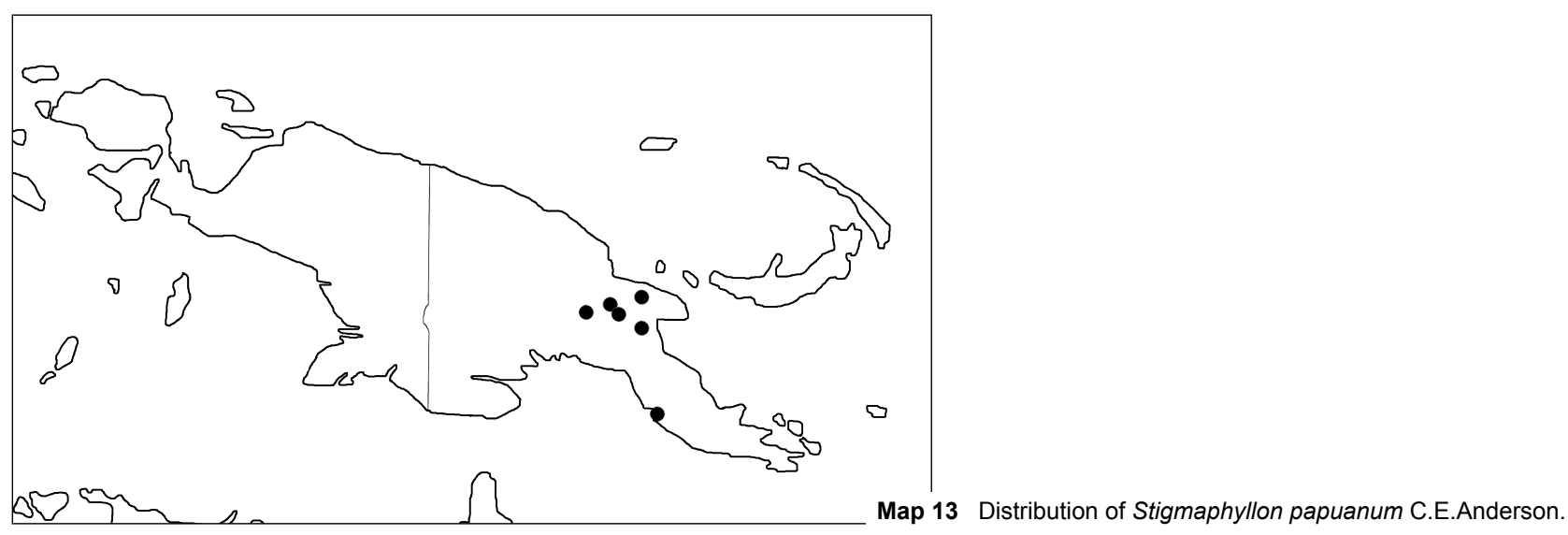

Habitat \& Phenology - Altitude from sea level to $1700 \mathrm{~m}$; montane forest and forest margin, near stream banks, and in secondary vegetation; collected in flower in November, January, February, April, May, and July, in fruit in May.

Additional specimens examined. Papua New Guinea, Central, P. Moresby subdistr., near Tatana Village, Fairfax Harbor, 09 $30^{\circ} \mathrm{S}, 147^{\circ} 10^{\prime} \mathrm{E}, 10 \mathrm{ft}, 23$ Feb. 1972, Womersley NGF 43879 (CANB, L). Eastern Highlands, Crater Mt Wildlife Management Area, near Hauneababo, 06 $43^{\circ} \mathrm{S}, 145^{\circ} 00^{\prime} \mathrm{E}, 5600$ ft, 24 July 1998, Takeuchi 12564 (A, CANB, K, L); Okasa, Okapa, 06³5'S, 14540'E, 5500 ft, 17 May 1967, Womersley NGF 24929 (A, BRI, CANB, K, L, NSW, SING). Morobe, Wantoat [Wantot], 4000 ft, 15 Jan. 1940, Clemens 10988 (A, MICH); Mumeng Distr., 07²0'S, 146 $45^{\prime} \mathrm{E}, 3400 \mathrm{ft}, 14 \mathrm{Nov}$. 1963, Millar NGF 18826 (A, BRI, CANB, E, K, NSW, SING); Wau, 07²0'S, $146^{\circ} 45^{\prime} \mathrm{E}, 5500 \mathrm{ft}, 1$ Apr. 1965, Millar NGF 23875 (A, CANB).

Note - Stigmaphyllon papuanum differs from the other two species of subg. Ryssopterys in New Guinea with sparsely sericeous to glabrate leaves in its bractlike triangular stipules, the short stout styles (c. $1.5 \mathrm{~mm}$ long) in hermaphrodite flowers, and a longer dorsal wing on the samara $(3.5-4.5 \mathrm{~mm})$. Both S. mariae and $S$. timoriense have leaflike stipules, filiform styles c. $3.5 \mathrm{~mm}$ long, and samaras with a dorsal wing $2.5-3.5 \mathrm{~mm}$ long.

\section{Stigmaphyllon pullenii C.E.Anderson, sp. nov. - Fig. 7; Map 1}

Differt a S. micrantho stipulis foliosis, sepalis $2-2.5 \mathrm{~mm}$ longis, petalis $5.5-7.5$ mm longis, stylis 3-4.5 mm longis. - Typus: Pullen 6613 (holo CANB; iso A, BRI, K, L), Papua New Guinea, Central Prov., Rubulogo Creek, c. 18 mi $\mathrm{N}$ of Port Moresby, $100 \mathrm{ft}, 6$ Apr. 1967.

Etymology. This species is named in honour of Royal Pullen (1925-2009). His excellent collections gathered during his many years of exploring Papua New Guinea are an invaluable resource for any botanist concerned with the flora of New Guinea.

Vine; stems densely sericeous when young, older parts glabrate to glabrous. Laminas of the larger leaves $6.5-13.5$ by $4.5-11$ $\mathrm{cm}$, ovate to broadly elliptical to suborbicular, apex roundedapiculate or emarginate-apiculate, base truncate to shallowly cordate, adaxially sericeous when young but soon glabrate to glabrous, abaxially tomentose, the hairs $0.4-1.2 \mathrm{~mm}$ long, wavy or straight, subsessile or with a stalk to $0.1 \mathrm{~mm}$ long, secondary veins prominent abaxially; marginal glands $0.3-0.6$ $\mathrm{mm}$ diam; petioles $2-5 \mathrm{~cm}$ long, densely sericeous, with a pair of glands borne at apex, each gland 1-2.5 mm diam, slightly prominent; stipules 2 on each side of petiole, leaflike, larger stipules to $8 \mathrm{~mm}$ long, to $2.5 \mathrm{~mm}$ wide, oblong to obspatulate, smaller stipules to $4 \mathrm{~mm}$ long, to $1 \mathrm{~mm}$ wide, linear, vesture like that of laminas. Hermaphrodite flowers c. 15-35 flowers in each pseudoraceme, borne in dichasia and compound dichasia; peduncles $3.5-11 \mathrm{~mm}$ long, pedicels $3-5.5 \mathrm{~mm}$ long, both densely sericeous, peduncles $1-3$ times as long as pedicels; bracts $1-1.3$ by $0.6-0.8 \mathrm{~mm}$, triangular, bracteoles $0.8-1$ by $0.5-0.6 \mathrm{~mm}$, oblong, bracts and bracteoles with scattered hairs abaxially and distally along the margin. Sepals $2-2.5$ by $1.5-2$ $\mathrm{mm}$, oblong to ovate, abaxially sericeous. Petals pale yellow or greenish cream, claw $0.5-0.8 \mathrm{~mm}$ long, limb $5.5-7.5$ by $5-6$ $\mathrm{mm}$, base attenuate or truncate, margin subentire or shallowly erose. Stamens 10; filaments 3-3.5 mm long, anthers 0.9-1 $\mathrm{mm}$ long, without apiculum, glabrous. Ovary c. $2 \mathrm{~mm}$ long; styles c. $3 \mathrm{~mm}$ long, c. $0.1 \mathrm{~mm}$ diam, stigma $0.4-0.5 \mathrm{~mm}$ diam, peltate and slightly off-centre. Male flowers: filaments 3-4 $\mathrm{mm}$ long, anthers 1-1.1 mm long, without apiculum, glabrous; ovary rudimentary, to $0.5(-1) \mathrm{mm}$ long, embedded in a tuft of hairs, styles 3 , free, $3.4-4.5 \mathrm{~mm}$ long, c. $0.1 \mathrm{~mm}$ diam, stigma $0.2-0.4 \mathrm{~mm}$ diam, peltate and slightly off-centre. Dorsal wing of samara $1.7-2$ by $1-1.2 \mathrm{~cm}$; nut $5-6.5 \mathrm{~mm}$ long, $3-3.5 \mathrm{~mm}$ diam, narrowly ovoid, prominently ridged and/or with spurs, lateral winglets absent or 1-3 per side, to $4 \mathrm{~mm}$ long, to 2.5 $\mathrm{mm}$ wide, areole $4.5-5.2$ by $1.2-1.7 \mathrm{~mm}$. Embryo c. 6.5 by c. $2 \mathrm{~mm}$, cotyledons subequal, 6.3 by c. $2 \mathrm{~mm}$, straight.

Distribution - Indonesia (1 collection from Papua); Papua New Guinea (Central, Morobe, National Capital).

Habitat \& Phenology - Altitude 20-700 m; in thickets, grassland, rain forest, and at forest margin; collected in flower from February to April, and July, in fruit in March to June.

Additional specimens examined. IndonesIA, Papua, [Jayapura] Distr. Hollandia, Cycloop Mts, Ifar, 150 m, 12 July 1967, Van Royen \& Sleumer 6163 (BRI, K, L). - Papua New Guinea, Central, Sogeri region, 09²8'45"S, $147^{\circ} 31^{\prime} 37 " E, 1885-1886$, Forbes 943 (K, L); Port Moresby, side rd off Brown River Rd opp. Mt Lawes, 2.5 mi N of Laloki R. bridge, 20 m, 28 Mar. 1971, Frodin \& Millar UPNG 567 (K, L); near Kwalimurubu village E of Port Moresby, $09^{\circ} 51^{\prime} \mathrm{S}, 147^{\circ} 36^{\prime} \mathrm{E}, 80 \mathrm{ft}, 9$ July 1962, Pullen 3245 (CANB); Rubulogo Creek, c. $18 \mathrm{mi} \mathrm{N}$ of Port Moresby, 120 ft, 9 Apr. 1967, Pullen 6658 (CANB, L); SE side of Little Mount Lawes, c. 16 mi N of Port Moresby, 160 ft, 25 Apr. 1967, Pullen 6806 (BRI, CANB, K, L); Vesoroga Creek, Sogeri Distr., $2200 \mathrm{ft}, 21$ June 1954, Womersley NGF 5805 (A, BRI, L). Morobe, below Wareo, 1800 $\mathrm{ft}, 8$ Feb. 1936, Clemens 1798 (A, BR); unteres Bumigebiet, bei Finschhafen, 1889-1891, Weinland 363 (BRI, K, L, NSW, SING). National Capital, Rouna Falls, 400 m, 3 May 1940, Batten Pooll s.n. (NSW); Koitaki, 1500 ft, 22 Apr. 1935, Carr 12004 (A, CANB, L, SING).

Notes - Stigmaphyllon pullenii differs from the other New Guinea species by the combination of laminas abaxially densely tomentose (the vesture never appressed), leaflike stipules, male flowers with filiform styles $3.4-4.5 \mathrm{~mm}$ long, and samaras with a short dorsal wing (1.7-2 cm long). The laminas of $S$. brassii and S. micranthum are densely sericeous (the vesture appressed); the male flowers lack styles. Also, S. micranthum differs in its much smaller flowers and bractlike triangular stipules. The dorsal wing of samaras of $S$. brassii is $3-4.5 \mathrm{~cm}$ long; samaras of $S$. micranthum are unknown.

The calyx in the collection Weinland 363 is one of two collections seen in which some of the sepals bear a rudimentary commissural gland (see Morphology above). 


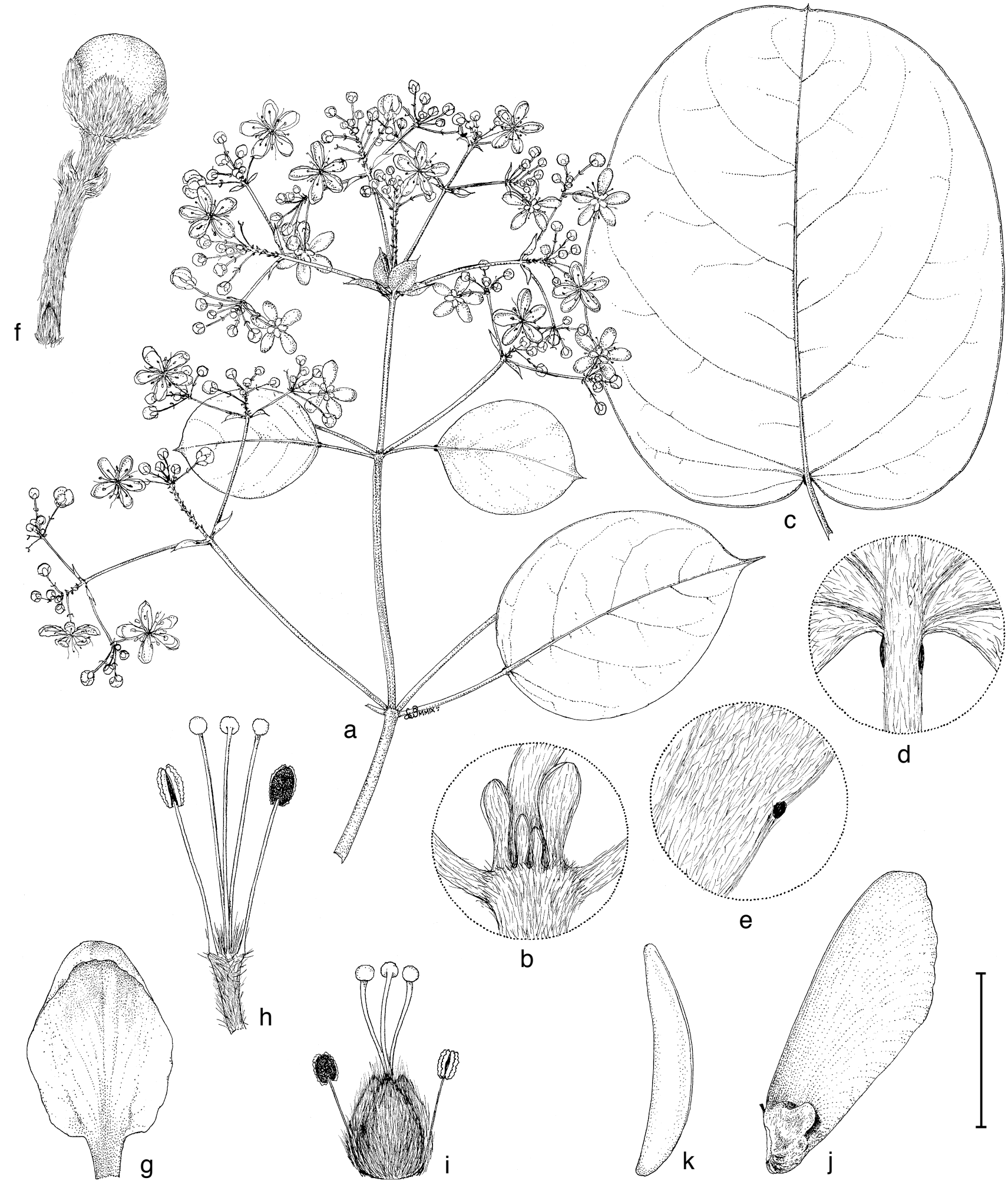

Fig. 7 Stigmaphyllon pullenii C.E.Anderson. a. Flowering branch; b. node with four stipules; c. large leaf; d. base of lamina with pair of glands; e. detail showing abaxial surface of lamina and marginal gland; f. flower bud with peduncle and pedicel; g. petal; h. parts of male flower: two stamens, three styles arising from a rudimentary ovary embedded in a tuft of hairs; i. parts of hermaphrodite flower: two stamens, gynoecium; j. samara; $\mathrm{k}$. embryo. - Scale bars: a, $\mathrm{c}=$ $4 \mathrm{~cm} ; \mathrm{b}, \mathrm{d}=8 \mathrm{~mm}$; e-i, $\mathrm{k}=4 \mathrm{~mm} ; \mathrm{j}=1.3 \mathrm{~cm}$ (a, f-h: Pullen 6658, CANB; b: Pullen 3245, CANB; c-e: Pullen 6613, CANB; i: Frodin \& Millar UPNG 567, K; j, k: Pullen 6806, CANB).

\section{Stigmaphyllon solomonense C.E.Anderson, sp. nov.} - Fig. 8; Map 14

Differt a S. discolori foliis glabris, stipulis foliosis, petalis c. $7 \mathrm{~mm}$ longis. - Typus: Forster \& Liddle PIF 8639 (holo K; iso BRI), Solomon Islands, Guadalcanal [Isatubo], Mbokokimbo River, near Mbeghoapilu Village, $09^{\circ} 28$ 'S, $160^{\circ} 22^{\prime} \mathrm{E}, 140 \mathrm{~m}, 19$ June 1991.

Vine [to c. $20 \mathrm{~m}$ ]; stems sericeous when young, soon glabrate to glabrous. Laminas of the larger leaves $7.5-13.5$ by $5-9 \mathrm{~cm}$, elliptical to ovate, apex apiculate to acuminate, base truncate or shallowly cordate, adaxially glabrous, abaxially sericeous when very young, soon glabrous or with scattered hairs retained especially on the costa and near the base, the hairs $0.3-1 \mathrm{~mm}$ long, straight, sessile or subsessile, secondary veins prominent abaxially; marginal glands $0.4-0.5 \mathrm{~mm}$ diam; petioles $1.5-4 \mathrm{~cm}$ long, sericeous, with a pair of glands borne at apex, each gland $1-1.8 \mathrm{~mm}$ diam, flush or slightly prominent; stipules $2(-3)$ on each side of petiole, leaflike, larger stipules to $8 \mathrm{~mm}$ long, to 8 


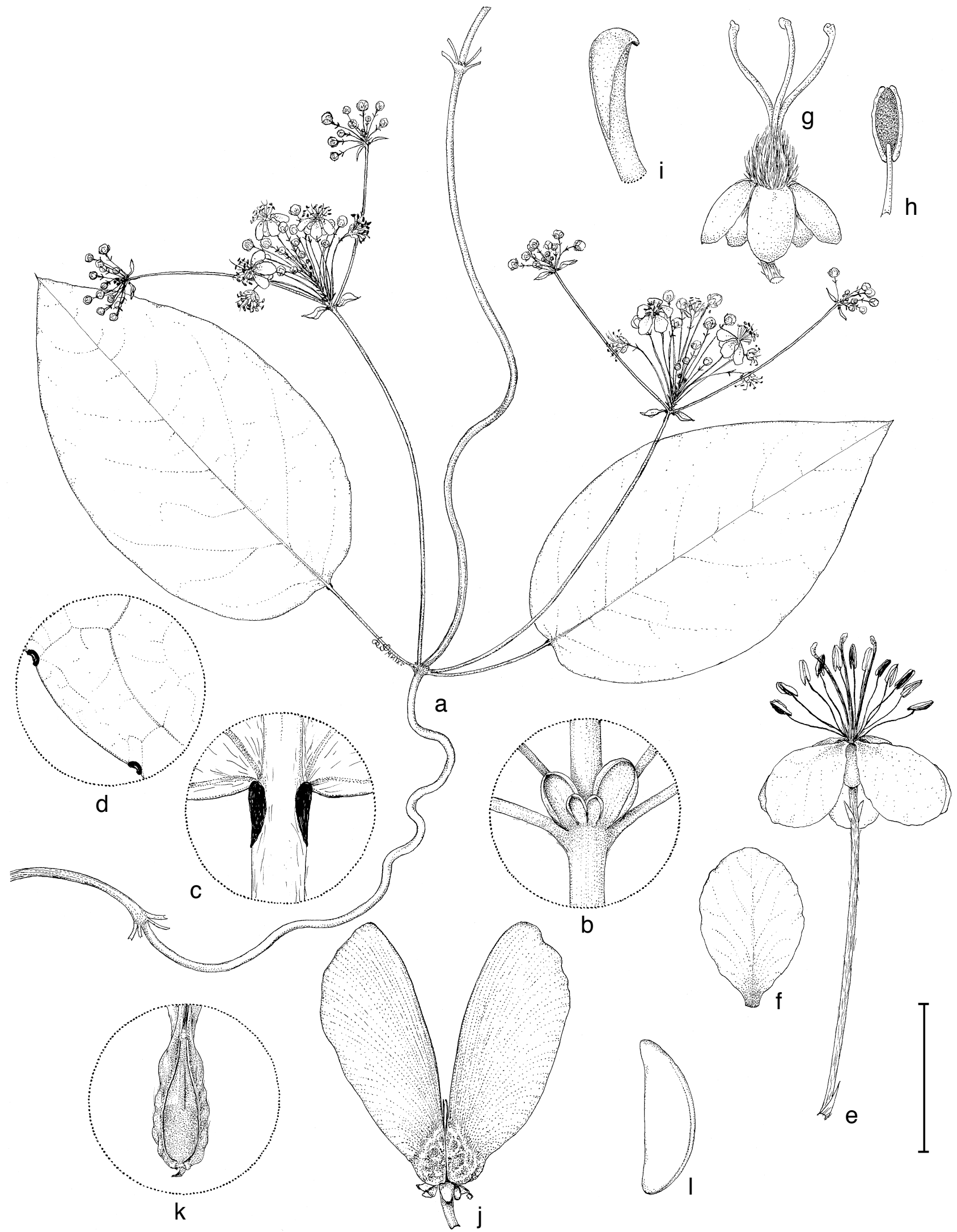

Fig. 8 Stigmaphyllon solomonense C.E.Anderson. a. Habit; b. node with four stipules; c. base of lamina with pair of glands; d. detail showing abaxial surface of lamina and two marginal glands; e. male flower with long peduncle and short pedicel; f. petal; g. hermaphrodite flower, corolla and androecium removed to show gynoecium and reflexed sepals; $h$. distal portion of stamen of hermaphrodite flower; i. distal portion of style of hermaphrodite flower; j. fruit, showing two of three samaras; $\mathrm{k}$. face view of samara, showing narrow areole; l. embryo. - Scale bars: $\mathrm{a}=4 \mathrm{~cm} ; \mathrm{b}, \mathrm{j}=2 \mathrm{~cm} ; \mathrm{c}, \mathrm{g}, \mathrm{I}=4 \mathrm{~mm} ; \mathrm{d}, \mathrm{h}=2.7 \mathrm{~mm} ; \mathrm{e}, \mathrm{k}=8 \mathrm{~mm}$; $\mathrm{f}=6.7 \mathrm{~mm} ; \mathrm{i}=0.8 \mathrm{~mm}$ (a, c-f: Forster \& Liddle PIF 8639, K; b: Ramo \& Nakisi BSIP 7895, L; g-i: Griffith 2/25, BRI; j-l: Regalado \& Sirikolo 808, L)

$\mathrm{mm}$ wide, deltate to broadly elliptical to suborbicular, smaller stipules to $0.7 \mathrm{~mm}$ long, to $0.5 \mathrm{~mm}$ wide, linear to narrowly triangular, abaxially with scattered hairs to sericeous. Hermaphrodite flowers c. 20 in each pseudoraceme, borne in dichasia and compound inflorescences; peduncles $6.5-21 \mathrm{~mm}$ long, pedicels
2-6 mm long, both densely sericeous, peduncles $1.6-5$ times as long as pedicels; bracts $1.2-1.6$ by $0.6-0.8 \mathrm{~mm}$, narrowly triangular, bracteoles $0.7-1.2$ by $0.4-0.6 \mathrm{~mm}$, oblong or narrowly triangular, bracts and bracteoles abaxially with scattered hairs. Sepals $1.8-2.3$ by $1.6-2 \mathrm{~mm}$, oblong to broadly ovate, 


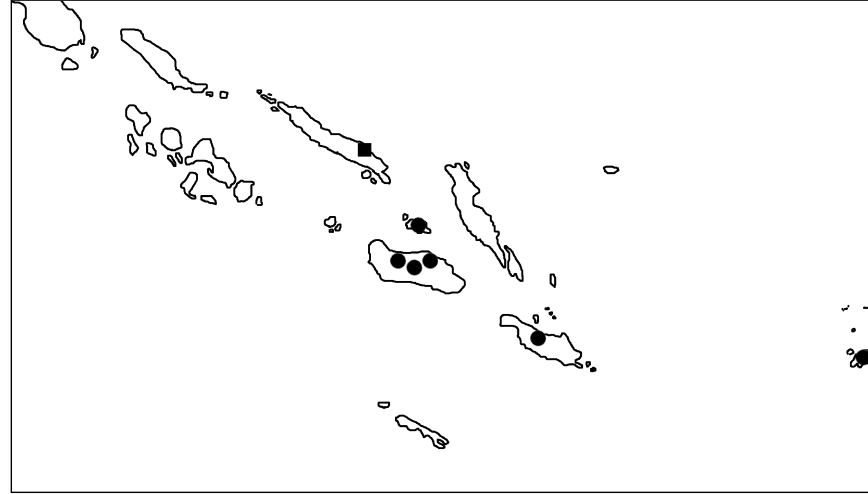

glabrous or with scattered hairs. Petals yellow, claw absent or to $0.2 \mathrm{~mm}$ long, limb c. $7 \mathrm{~mm}$ long and wide, base acute, margin shallowly erose. Stamens 12(-16); filaments 3-3.2 mm long, anthers 1.1-1.2 mm long, without apiculum, glabrous. Ovary c. $1.5 \mathrm{~mm}$ long; styles c. $3 \mathrm{~mm}$ long, c. $0.1 \mathrm{~mm}$ diam, apically extended into a tiny spur to c. $0.02 \mathrm{~mm}$ long, stigma c. $0.4 \mathrm{~mm}$ diam, peltate but laterally placed. Male flowers $15-35(-40)$ flowers per umbel or pseudoraceme; filaments 3-4.2 mm long, anthers $1-1.5 \mathrm{~mm}$ long, without apiculum, glabrous; ovary rudimentary, a mound of tissue to $0.6 \mathrm{~mm}$ high, embedded in a tuft of hairs; styles 3 , free, c. $5 \mathrm{~mm}$ long, c. $0.1 \mathrm{~mm}$ diam, stigma c. $0.2 \mathrm{~mm}$ diam, laterally placed, apex of style extended into a tiny spur c. $0.02 \mathrm{~mm}$ long. Dorsal wing of samara $2.9-3.1$ by c. $1.3 \mathrm{~cm}$; nut $7-8.5 \mathrm{~mm}$ long, 3-4 mm diam, narrowly ellipsoid, with prominent ridges, lateral winglets absent, areole 5.5-6.5 by $1.5-2 \mathrm{~mm}$. Embryo c. $7.5 \mathrm{~mm}$ long, cotyledons subequal, c. 7 by c. $2 \mathrm{~mm}$, straight.

Distribution - Solomon Islands.

Habitat \& Phenology - Altitude 30-450 m; lowland rain forest and along beaches; collected in flower in March, April, and June, in fruit in July and August.

Additional specimens examined. Solomon IsLANDS, Guadalcanal, Mt Austen area, $09^{\circ} 28^{\prime} \mathrm{S}, 159^{\circ} 58^{\prime} \mathrm{E}, 160 \mathrm{~m}, 17$ June 1991, Forster \& Liddle PIF 8615 (BRI); Guadalcanal, Kupers Pit, Gold Ridge, $09^{\circ} 35^{\prime} \mathrm{S}, 160^{\circ} 08^{\prime} \mathrm{E}, 450 \mathrm{~m}$, 18 Mar. 1990, Griffith 2/25 (BRI); Sole Arsa, Nggela Island, 425 ft, 30 Mar. 1970, Mauriasi et al. BSIP 18205 (L); Guadalcanal, Mt Mambulu northern slope, 800 ft, 19 July 1967, Nakisi BSIP 8017 (K, L); Santa Cruz Isl., Eastern Distr., Nanggu Village area, 14 Apr. 1972, Powell BSIP 19870 (CANB, L); NW Guadalcanal, Rove Valley area, $100 \mathrm{ft}, 17$ May 1967, Ramo \& Nakisi BSIP 7895 (L, SING); Guadalcanal, Mt Austen, $8 \mathrm{~km} \mathrm{~S}$ of Honiera, $09^{\circ} 26^{\prime} \mathrm{S}$, $159^{\circ} 57^{\prime} \mathrm{E}, 250 \mathrm{~m}, 12$ Aug. 1993, Regalado \& Sirikolo 808 (L).

Note - Stigmaphyllon solomonense is unusual in that the flowers have 12(-16) stamens, a character otherwise found only in $S$. discolor and S. mackeeanum. Both differ in their bractlike triangular stipules and larger petals ( $8.5-10 \mathrm{~mm}$ long). Stigmaphyllon mackeeanum, from New Caledonia, lacks styles in the male flowers; the dorsal wing of the samaras is c. $2 \mathrm{~cm}$ long. Stigmaphyllon discolor has been collected once on Santa Isabel Island but otherwise is known only from New Caledonia. It is immediately separated from the glabrous $S$. solomonense by the dense vesture of most of its vegetative parts.

\section{Stigmaphyllon sundaicum C.E.Anderson, sp. nov. - Fig. 9; Map 10}

Differt a $S$. albido foliis glabris, petalis 6-6.5 mm longis, antheris non apiculatis. - Typus: Mitchell 7241 (holo BRI), East Timor, Lubang de Jakarta, 5.2 km from Ainaro on a bearing of $178^{\circ}, 09^{\circ} 02^{\prime} 21^{\prime \prime S}, 125^{\circ} 30^{\prime} 34^{\prime \prime E}, 4$ May 2002.

Vine [to $15 \mathrm{~m}$ ]; stems sericeous when very young, soon glabrescent to glabrous. Laminas of the larger leaves $5.5-13$ by $3.7-10 \mathrm{~cm}$, narrowly to broadly ovate to cordate or suborbicular, apex acuminate to caudate, base cordate to auriculate but in smaller ovate leaves often truncate, adaxially glabrous, abaxi- ally glabrate to glabrous at maturity but often with some hairs retained along the major veins, the hairs $0.2-0.6 \mathrm{~mm}$ long, straight to wavy, sessile, secondary veins prominent and tertiary veins prominulous abaxially; marginal glands $0.3-0.4 \mathrm{~mm}$ diam; petioles $3-6.5 \mathrm{~cm}$ long, glabrate to glabrous, with a pair of glands borne at apex or up to $2.5 \mathrm{~mm}$ below the lamina base, each gland 1.3-1.7 mm diam, shallowly cup-shaped; stipules 1 (rarely 2) on each side of petiole, triangular, bractlike, 0.5-1.1 by $0.3-1 \mathrm{~mm}$, triangular, glabrous. Hermaphrodite flowers c. 10-25 in each pseudoraceme or umbel, borne in dichasia; peduncles $2.5-11 \mathrm{~mm}$ long, pedicels $3-4.5 \mathrm{~mm}$ long, both densely sericeous, peduncles $0.6-3$ times as long as pedicels; bracts $1.3-1.7$ by $0.5-0.8 \mathrm{~mm}$, narrowly triangular, bracteoles $0.7-1.2$ by c. $0.4 \mathrm{~mm}$, oblong, bracts and bracteoles abaxially sericeous or with scattered hairs. Sepals $2-2.2$ by $1.8-2 \mathrm{~mm}$, ovate to broadly ovate, sericeous. Petals yellow, claw $0.1-0.5$ $\mathrm{mm}$ long, limb 6-6.5 mm long and wide, base briefly truncate, margin subentire or shallowly erose. Stamens 10; filaments 2.5-3 mm long, anthers c. $1.2 \mathrm{~mm}$ long, without apiculum, glabrous or with a few scattered hairs. Ovary 1.7-1.8 mm long, styles 2-2.5 mm long, c. $0.2 \mathrm{~mm}$ diam, stigma $0.3-0.4 \mathrm{~mm}$ diam, peltate. Male flowers: filaments $2.7-3 \mathrm{~mm}$ long; anthers $1.5-1.6 \mathrm{~mm}$ long, without apiculum, glabrous or with a few scattered hairs; ovary rudimentary, a mound of tissue to $0.2 \mathrm{~mm}$ long, receptacle with or without a tuft of hairs, styles absent. Dorsal wing of samara $3-3.6$ by $1-1.5 \mathrm{~cm}$; nut $7-7.5 \mathrm{~mm}$ long, $4.5-5$ $\mathrm{mm}$ diam, spheroid, prominently ribbed, lateral winglets absent; areole $4-4.2$ by $1.5-3.5 \mathrm{~mm}$. Embryo c. 5 by c. $3 \mathrm{~mm}$, spheroid, cotyledons convoluted and folded within each other.

Distribution - Indonesia (Alor, Flores, Sumba), East Timor.

Habitat \& Phenology - Altitude 100-1 $450 \mathrm{~m}$; shrubland and secondary forest; collected in flower in November and May, in fruit from March to May.

Additional specimens examined. INDONESIA, Alor, Kabola Peninsula, from Kalabahi to Kabola, 450 m, 1 May 1938, Jaag 201 (K, L); highland of Kabola Peninsula, 720 m, 3 May 1938, Jaag 349 (A, L); Koli, Moroe-Gendok, 200 m, 7 May 1938, Jaag 602 (A, L); Kalabahi-Likreatang (north coast), 9 May 1938, Jaag 739 (L, SING); Woisiha-Saumassi, 21 May 1938, Jaag 1405 (L). Flores, 150 m, 17 Apr. 1984, Afriastini 1554 (K, L); Geli Moeto [= Keli Muto], 1450 m, 5 Nov. 1932, Posthumus 3090 (A, L, SING); Kadang-Nisar, 400 m, 10 Mar. 1974, Schmutz 3616 (L); Manggarai, 100 m, 6 May 1978, Schmutz 4116 (L). Sumba, Kabaroe (Waingapoe), 17 Mar. 1925, Iboet 14 (BR, L, P).

Note - Stigmaphyllon sundaicum is sympatric with S. albidum and S. timoriense. Like S. albidum, it has bractlike triangular stipules and embryos with convoluted cotyledons, but its laminas are glabrous abaxially, and the petiole glands are usually placed $1-2.5 \mathrm{~mm}$ below the base of the lamina. In $S$. albidum the laminas are abaxially tomentose, and the petiole glands are borne at the apex of the petiole. Stigmaphyllon timoriense has glabrous leaves but leaflike stipules, petiole glands borne at the apex of the petiole, and usually pubescent anthers. The anthers of $S$. sundaicum are usually glabrous but sometimes bear a few scattered hairs. 


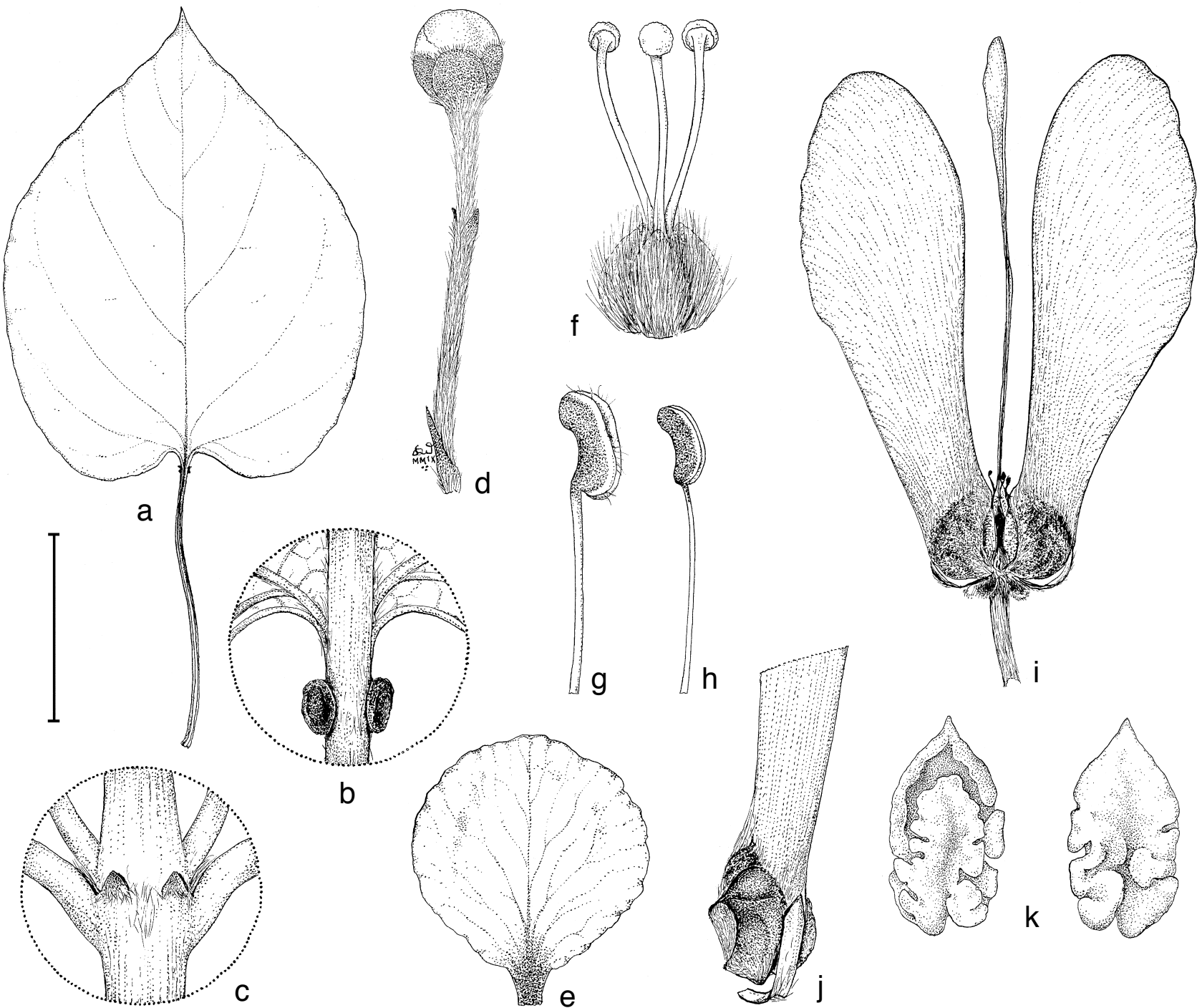

Fig. 9 Stigmaphyllon sundaicum C.E.Anderson. a. Leaf; b. base of lamina and apex of petiole with pair of glands; c. node with triangular stipules; d. flower bud with peduncle and pedicel; e. petal; f. gynoecium of hermaphrodite flower; g. distal portion of stamen from male flower; h. distal portion of stamen from hermaphrodite flower; i. fruit, with samaras beginning to separate; j. base of samara to show broad carpophore; $\mathrm{k}$. embryo, front and back. - Scale bars: $a=$ $4 \mathrm{~cm} ; \mathrm{b}, \mathrm{d}=4 \mathrm{~mm} ; \mathrm{c}, \mathrm{j}=8 \mathrm{~mm} ; \mathrm{e}, \mathrm{k}=5 \mathrm{~mm} ; \mathrm{f}-\mathrm{h}=2.7 \mathrm{~mm} ; \mathrm{i}=1.3 \mathrm{~cm}$ (a, b, e, f, h: Mitchell 7241, BRl; c, d, g: Jaag 349, L; i-k: Afriastini 1554, K).

20. Stigmaphyllon taomense (Baker f.) C.E.Anderson, comb. nov. - Map 9

Stigmaphyllon taomense (Baker f.) C.E.Anderson. - Ryssopterys taomensis Baker f., J. Linn. Soc., Bot. 45 (1921) 278. - Type: Compton 2286 (holo BM), New Caledonia, Mt Taom, 200 ft, 30 Nov. 1894.

Vine [to $4 \mathrm{~m}$ ]; stems sericeous when young, eventually glabrous. Laminas of the larger leaves $3.5-7.5$ by $2.5-6 \mathrm{~cm}$, lanceolate to elliptical to broadly ovate, apex apiculate, base truncate or slightly cordate, adaxially sericeous when young but soon glabrescent to glabrous, abaxially sericeous but in old leaves the vesture unevenly deciduous, the hairs $0.3-0.8 \mathrm{~mm}$ long, straight or wavy, sessile, appressed and mostly parallel, also with scattered subsessile to stalked hairs to $1.1 \mathrm{~mm}$ long (stalk to $0.1 \mathrm{~mm}$ long), secondary veins prominent and tertiary veins prominulous abaxially; marginal glands c. $0.3 \mathrm{~mm}$ diam or absent; petioles $0.9-3 \mathrm{~cm}$ long, densely sericeous to glabrescent in old leaves, with a pair of glands borne at apex or on the base of the lamina above insertion of the petiole, each gland $0.5-1.2 \mathrm{~mm}$ diam, slightly prominent or projecting up to $0.5 \mathrm{~mm}$ above the leaf epidermis and cup-shaped, sometimes with a smaller secondary gland to $0.4 \mathrm{~mm}$ diam; stipules 1 on each side of petiole, triangular, bractlike, to $1.3 \mathrm{~mm}$ long, to 0.8 $\mathrm{mm}$ wide, abaxially sericeous, sometimes with an additional smaller stipule. Hermaphrodite flowers (6-)8-15 in a solitary umbel; peduncles 1.5-6 mm long, pedicels (2.5-)4-6 mm long, both densely sericeous, peduncles $0.3-1$ time as long as pedicels; bracts $1.1-1.5(-2)$ by $0.6-0.7 \mathrm{~mm}$, narrowly triangular, bracteoles $1-2$ by $0.4-0.6 \mathrm{~mm}$, linear or narrowly triangular, bracts and bracteoles abaxially with scattered hairs. Sepals $1.8-3$ by $1.8-2.5 \mathrm{~mm}$, broadly ovate, sericeous or glabrous along the margin. Petals yellow, claw 0.5-1 mm long, limb 7-9 $\mathrm{mm}$ long and wide, base acute or briefly truncate, margin subentire or shallowly erose. Stamens 10; filaments 3-3.3 mm long, anthers 1.1-1.2 mm long, without apiculum, glabrous. Ovary c. $1.6 \mathrm{~mm}$ long, styles $3.5-4.2 \mathrm{~mm}$ long, c. 0.1 diam, stigma $0.3-0.4 \mathrm{~mm}$ diam, peltate, terminal but slightly lateral. Male flowers: filaments $2.8-3.5 \mathrm{~mm}$ long, anthers $1.3-1.5 \mathrm{~mm}$ long; ovary rudimentary, a tiny mound of tissue to $0.1 \mathrm{~mm}$ high, embedded in a tuft of hairs; styles 3 , free or 2 variously united, 3.5-4 mm long, free style $0.1 \mathrm{~mm}$ diam, stigma $0.3 \mathrm{~mm}$ diam, peltate. Dorsal wing of samara $2.2-2.5$ by $1-1.5 \mathrm{~cm}$; nut c. 5 $\mathrm{mm}$ long, c. $4 \mathrm{~mm}$ diam, ovoid, with prominent ridges, lateral winglets absent, areole $2.5-3 \mathrm{~mm}$ long and wide; mature seed not seen.

Distribution - New Caledonia including Loyalty Islands.

Habitat \& Phenology - Altitude 30-250 m; in forest, on serpentine and calcareous substrates; collected in flower from December to February, once in fruit in February. 
Additional specimens examined. New CALEdoniA, Lifu Island South, Cap des Pins, Jan. 1950, Cheesman 3364 (US); Ile Maré, Loyalty, Jan. 1908, Franc 922 (A, NY, UC); Pain de Sucre, 22 Dec. 1950, Guillaumin \& Baumann 9734 (BRI); cretes calcaires rocheuses au SE de la corne de Koumac, 250 m, 27 Dec. 1972, MacKee 26101 (MICH); Lifou, Mutchaweng, 30 m, 18 Feb. 1974, MacKee 28179 (MICH); Lifou, hauteurs au SE du Cap Lafon, 90 m, 22 Feb. 1974, MacKee 28295 (MICH); lle Art, Plateau Nord, 150 m, 8 Dec. 1975, MacKee 30401 (MICH); Koumac, Oué Ambouch, 200 m, 24 Jan. 1979, MacKee 36515 (MICH); Lifou, région de Wé, 16 Feb. 1966, Schmid 1038 ( $\mathrm{MICH}, \mathrm{P})$.

Notes - Stigmaphyllon taomense is easily separated from other species of subg. Ryssopterys of New Caledonia by the finely sericeous vesture on the abaxial lamina. In $S$. discolor and S. mcphersonii the laminas are tomentose abaxially, and in the other species they are abaxially glabrous or at most very sparsely sericeous. Also, the flowers of $S$. discolor have 12-16 stamens and are commonly borne in compound inflorescences. Stigmaphyllon mcphersonii has smaller flowers (petals 6-7 mm diam) borne 4-6 per umbel, and the male flowers lack styles. In $S$. taomense the petals measure $7-9 \mathrm{~mm}$ in diameter, the stamens number 10, and male flowers have three styles arising from a minute 'ovary' (c. $0.1 \mathrm{~mm}$ long), but only one is free and the other two are variously united.

On the handwritten label of the holotype the elevation is given as $200 \mathrm{ft}$; presumably, the figure of ' $2000 \mathrm{ft}$ ' in the protologue is a typographical error.

\section{Stigmaphyllon timoriense(DC.) C.E.Anderson, comb. nov. - Map 10}

Stigmaphyllon timoriense (DC.) C.E.Anderson. - Banisteria timoriensis DC., Prodr. 1 (1824) 588. - Ryssopterys timoriensis (DC.) A.Juss. in Delessert, Icon. Sel. PI. 3 (1838, '1837') 21, pl. 35. - Type: unknown collector (holo G-DC), Timor.

Hiraea obscura Blume (1825) 226. - Type: unknown collector (holo L), Timor [erroneously Java in protologue].

Hiraea ovata Blume (1825) 226. - Type: unknown collector (holo L), Timor [erroneously Java in protologue].

Ryssopterys timoriensis forma amboinensis Nied. (1915) 59. - Type: Warburg 17408 (holo B十), Indonesia, Ambon.

Vine [3 $\mathrm{m}$ ]; stems sericeous when young, soon becoming glabrous. Laminas of the larger leaves $6-17$ by $3.2-11.5$ $\mathrm{cm}$, lanceolate to elliptical to ovate to cordate or sometimes suborbicular, apex acuminate or especially in smaller leaves apiculate, base truncate to cordate or auriculate, adaxially glabrous, abaxially sparsely sericeous when young but usually eventually glabrate to glabrous, vesture sometimes sloughed off in patches, often hairs retained near costa and secondary veins, the hairs $0.4-2.2 \mathrm{~mm}$ long, straight or wavy, sessile or subsessile, secondary veins prominent abaxially; marginal glands $0.3-0.5 \mathrm{~mm}$ diam; petioles $2-7 \mathrm{~cm}$ long, densely sericeous but glabrate in age, with a pair of glands borne at apex, each gland $1.3-3 \mathrm{~mm}$ diam, prominent; stipules $2(-3)$ on each side of petiole, leaflike, larger stipules to $14 \mathrm{~mm}$ long, to $6 \mathrm{~mm}$ wide, elliptical to obovate, the largest divided into a small petiole and lamina, smaller stipules to $4.5 \mathrm{~mm}$ long, to $2 \mathrm{~mm}$ wide, strap-shaped, all abaxially sparsely sericeous to glabrate. Hermaphrodite flowers c. 10-30 in each pseudoraceme, borne in dichasia or compound inflorescences; peduncles 4-6.5 mm long, pedicels $3-7(-12) \mathrm{mm}$ long, both densely sericeous, peduncles $0.5-3$ times as long as pedicels; bracts $1.2-2$ by $0.6-1 \mathrm{~mm}$, narrowly triangular, bracteoles $1-1.8$ by $0.4-0.8$ $\mathrm{mm}$, oblong, bracts and bracteoles abaxially with scattered hairs. Sepals $2-3.3$ by $2-2.2 \mathrm{~mm}$, elliptical to ovate, apex rounded, sericeous or distally glabrate to glabrous. Petals yellow, claw $0.3-0.7(-1.5) \mathrm{mm}$ long, limb $6-8.5$ by $6-8 \mathrm{~mm}$, base acute or truncate, margin shallowly erose or denticulate-erose. Stamens 10(-12); filaments 3.1-3.3 mm long, anthers c. 1.2 $\mathrm{mm}$ long, without apiculum but the apex often minutely acute, or rarely with an apiculum to $0.1 \mathrm{~mm}$ long, usually pubescent or sometimes sparsely so (or rarely glabrous). Ovary c. $2.2 \mathrm{~mm}$ long; styles 3.5-3.6 mm long, c. $0.1 \mathrm{~mm}$ diam, stigma c. 0.3 $\mathrm{mm}$ diam, peltate. Male flowers: filaments $3.3-3.7 \mathrm{~mm}$ long; anthers 1.6-1.8 $\mathrm{mm}$ long, without apiculum but the apex often minutely acute, or rarely with an apiculum to $0.1 \mathrm{~mm}$ long, usually pubescent, sometimes sparsely so (or rarely glabrous); ovary rudimentary, c. $0.3 \mathrm{~mm}$ long, embedded in a tuft of hairs; styles absent, or rarely with $1(-3)$ hairlike styles. Dorsal wing of samara $2.5-3.3$ by $1-1.5 \mathrm{~cm}$; nut (7-)8-9.5 mm long, $3.5-4$ $\mathrm{mm}$ diam, narrowly ovoid, prominently ridged and/or bearing spurs, lateral winglets absent or 1-3 and $3 \mathrm{~mm}$ long, areole 5-7 by $2-3.5 \mathrm{~mm}$. Embryo $7.5-8.5 \mathrm{~mm}$ long, narrowly cylindrical, cotyledons $7-8$ by c. $2 \mathrm{~mm}$, straight.

Distribution - Australia (Queensland), East Timor, Indonesia (Babar, Morotai, Sulawesi, Tanimbar Islands, Timor, Wetar; Papua), Japan (Ryukyu: Mayako Island), Malaysia (Sabah: Boheydulong Island), Micronesia (Chuuk), Palau (Babeldaob, Koror), Papua New Guinea (Central Prov., Manus Island, New Ireland), Philippines (Tawitawi), Taiwan (Lan-yu Island); New Caledonia (?, see Notes below).

Habitat \& Phenology - Altitude from sea level to $400 \mathrm{~m}$; thickets, coastal forest, rain forest, secondary growth, and disturbed areas; collected in flower from January to June and in October, in fruit in April, June, October, and November.

Notes - Stigmaphyllon timoriense is the most widespread species of subg. Ryssopterys and also the most variable. As noted under Taxonomic History, the name Ryssopterys timoriensis traditionally has been applied indiscriminately to any collection of subg. Ryssopterys, and reports in the literature of $S$. timoriense from areas not listed above under Distribution may well be erroneous. The combination of leaflike stipules, glabrous leaves, 10 stamens with pubescent anthers, hermaphrodite flowers with the styles c. $3.5 \mathrm{~mm}$ long, male flowers without styles, samaras with the dorsal wing $2.5-3.3 \mathrm{~cm}$ long, and elongate embryos with equal straight cotyledons usually serves to separate $S$. timoriense from other species. Occasionally, the anthers are only sparsely pubescent and sometimes even glabrous; also, spent anthers retained in very old flowers or in fruiting material may have lost the hairs. Rarely, the male flowers may have some vestigial styles, e.g., a dissected bud taken from the BRI sheet of Croft \& Lelean LAE 65393 showed two hair-like styles; flowers of the duplicates at $A$ and CANB do not have styles. Other deviations may also be found; e.g., flowers of Buwalda 4368 (A, L, SING) have 12 stamens.

During this study I did not see any collections of $S$. timoriense from New Caledonia, but the report of its presence there by Guillaumin (1948) may be accurate and not an instance of misapplication of the name. In Guillaumin's key (p. 174) the lead for $R$. timoriensis describes the pubescent anthers and the most commonly found shape of the lamina.

\section{EXCLUDED NAMES}

Ryssopterys sect. Tiliodes Nied. (1915) 57. - The name is not validly published, because the section includes the type of the genus, Ryssopterys timoriensis DC. (ICBN Article 22).

Ryssopterys ovata Turcz. (1863) 583 = Aspidopterys concava Turcz.

Ryssopterys rufescens Turcz. (1863) $583=$ Aspidopterys tomentosa (Blume) A.Juss.

Ryssopterys tomentosa Blume ex A.Juss. (1843) 514, pro syn.

Acknowledgements I thank W.R. Anderson for his comments and suggestions. Karin Douthit drew the beautiful illustrations. I am grateful to W.R. Anderson and C.C. Davis for sharing with me the results of their research on the phylogeny of the Malpighiaceae. I thank the directors, curators, and 
staff of the following herbaria for providing access to their collections and courtesies during visits: A, BM, BR, BRI, C, CANB, E, GOET, K, L, MICH, MO, NSW, NY, P, SING, TAI, UC, US, WAG. I am especially indebted to J. Hunnex (BM), J. Heinrichs (GOET), G. Challen and S. Zmarzty (K), S. Kofman and J.F. Veldkamp (L), and C. Loup (P) for their advice and assistance. This study was supported in part by a grant from the National Science Foundation to the University of Michigan (DEB-0543909).

\section{REFERENCES}

Anderson C. 1997. Monograph of Stigmaphyllon (Malpighiaceae). Systematic Botany Monographs 51: 1-313.

Anderson C. 2000. Stigmaphyllon hispidum (Malpighiaceae), a new species from Bahia, Brazil. Novon 10, 2: 107-109.

Anderson C. 2007. Revision of Galphimia (Malpighiaceae). Contributions from the University of Michigan Herbarium 25: 1-82.

Anderson C. 2009. Stigmaphyllon lanceolatum (Malpighiaceae), a new species from Espírito Santo, Brazil. Harvard Papers in Botany 14: 193-196.

Anderson GJ, Symon DE. 1989. Functional dioecy and andromonoecy in Solanum. Evolution 43: 204-219.

Anderson WR. 2001. Observations on the Malagasy genus Rhynchophora (Malpighiaceae). Contributions from the University of Michigan Herbarium 23: $53-58$.

Baker EG. 1921. Plants from New Caledonia and the Isle of Pines. Polypetalae. Journal of the Linnean Society, Botany 45: 245-325.

Blume CL. 1825-1827. Bijdragen tot de flora van Nederlandsch Indië. Jakarta.

Cameron KM, Chase MW, Anderson WR, Hills HG. 2001. Molecular systematics of Malpighiaceae: Evidence from plastid rbcL and matK sequences. American Journal of Botany 88: 1847-1862.

Davis CC, Anderson WR. 2010. A complete phylogeny of Malpighiaceae inferred from nucleotide sequence data and morphology. American Journal of Botany 97: 2031-2048.

Davis CC, Anderson WR, Donoghue MJ. 2001. Phylogeny of Malpighiaceae: Evidence from chloroplast ndhF and trnl-F nucleotide sequences. American Journal of Botany 88: 1830-1846.

De Candolle AP. 1824. Malpighiaceae. In: De Candolle AP, Prodromus systematis naturalis regni vegetabilis 1: 577-592. Paris, Treuttel \& Würtz.

Gandoger M. 1913. L'herbier africain de Sonder (suite et fin). Bulletin de la Société Botanique de France 60: 454-462.

Guillaumin A. 1932. Matériaux pour la flore de la Nouvelle-Calédonie XXX. - Revision des Malpighiacées. Bulletin de la Société Botanique de France 79: $515-516$

Guillaumin A. 1942. Contributions a la flore de la Nouvelle-Calédonie LXXVII. Plantes de collecteurs diverses. Bulletin du Muséum National d'Histoire Naturelle, Paris, sér. 2, 14: 286-290.

\section{IDENTIFICATION LIST}

The numbers after the collector numbers refer to the following species:

$$
\begin{aligned}
& 1=S . \text { abutilifolium } \\
& 2=S . \text { albidum } \\
& 3=S . \text { angustifolium } \\
& 4=S . \text { australiense } \\
& 5=S . \text { brassii }
\end{aligned}
$$

$$
\begin{aligned}
6 & =S . \text { dealbatum } \\
7 & =S . \text { discolor } \\
8 & =\text { S. grandifolium } \\
9 & =\text { S. gymnopodum } \\
10 & =\text { S. intermedium }
\end{aligned}
$$

Afriastini 1554: 19 -Anderson 796: 21; 2872: 4

Backer 6530: 2; 11700: 2; 13096: 2; 16587: 2 - Bakhuizen 1913: 2; 2568: 2 - Balansa 1037: 3; 1038a: 7; 3524: 9 - Bamps 5834: 7 - Bancroft 46: 4; 207: 4 - Bartlett 15487: 6 - Batianoff 11368: 4; 900348: 4; 9403113: 4; 9405150: 4 - Batianoff \& Smith 900102: 4; 900103: 4 - Baumann 6463: 7; 9940: 7; 14489: 7 - Bean 3303: 4; 4195: 4; 11556: 4; 14896: 4 - Béguin 1319: 15; 1654: 21 - Blake \& Webb 15683: 4 - Blanchon 1295: 13 - Bloembergen 3829: 21 - Brass 1588: 21; 3400: 7; 3672: 4; 3728: 5; 3767: 5 ; 21891: 5 ; 22161: 5; 25889: 5 ; 29206: 5; 29308: 5 - Brown HA 79: 12 - Brown R 7077: 21 - Buwalda 4223: 21; 4368: 21; 7425: 2 - Byrnes \& Clarkson 3662: 4

Cabalion 1352bis: 8; 2224: 8; 3029: 8 - Canfield 528: 21 - Canicosa 620: 6 - Carr 11816: 12; 11817: 12; 12004: 17; 13409: 15; 15589: 15; 16169: 15; 16181: 15 - Champion IGC 1726: 4 - Cheesman 3364: 20 - Chew RSNH 157: 8; RSNH 346: 8 - Clarkson 6353: 4 - Clason B 96: 2; B 102: 2 - Clemens 18: 5 ; 1798: 17; 10988: 16 - Coert 765: 2 - Colfs 281: 2 - Comins 39: 18 - Compton 134: 7; 779: 7 - Conklin PNH 18654: 6 - Coode \& Katik NGF 32735: 5 - Coode et al. NGF 29615: 21 - Cooper WWC 1702:
Guillaumin A. 1948. Flore analytique et synoptique de la Nouvelle-Calédonie; phanérogames. Paris, Office de la recherche scientifique colonial.

Hasskarl JK. 1858. Hortus bogoriensis descriptus. Amsterdam, Günst.

Hochreutiner BPG. 1904. Ryssopterys intermedium. Bulletin de I'Institut Botanique de Buitenzorg 19: 45.

Jacobs M. 1955. Malpighiaceae. In: Van Steenis CGGJ (ed), Flora Malesiana, Ser. I, 5, 2: 123-145. Jakarta, Noordhoff-Kolff N.V.

Jussieu A. 1838 ('1837'). Malpighiaceae. In: Delessert B, Icones selectæ plantarum: 18-21. Paris

Jussieu A. 1840. Malpighiacearum synopsis. Annales des Sciences Naturelles, sér. 2, 13: 247-291, 321-338.

Jussieu A. 1843. Monographie des malpighiacées. Archives du Muséum d'Histoire Naturelle, Paris 3: 5-151, 255-626, t. 1-23.

Lowrie SR. 1982. The palynology of the Malpighiaceae and its contribution to family systematics. PhD Thesis. University of Michigan, Ann Arbor. University Microfilms \#82-24999.

Merrill ED. 1915. Genera and species erroneously credited to the Philippine flora. Philippine Journal of Science 10C: 171-194.

Merrill ED. 1923. An enumeration of Philippine flowering plants, vol. 2. Manila, Bureau of Printing.

Niedenzu F. 1900. De genere Stigmatophyllo (pars posterior). Index lectionum in Lyceo regio hosiano brunsbergensi per aestatem: 1-32.

Niedenzu F. 1915. Malpighiaceae palaeotropicae. Arbeiten aus dem botanischen Institut der Kgl. Akademie in Braunsberg 6: 1-63.

Niedenzu F. 1928. Malpighiaceae. In: Engler A (ed), Das Pflanzenreich IV. 141: 1-870. Leipzig, Engelmann.

Pohl RW. 1965. Dissecting equipment and materials for the study of minute plant structures. Rhodora 67: 95-96.

Schumann K, Lauterbach K. 1905. Nachträge zur Flora der Deutschen Schutzgebiete in der Südsee. Leipzig, Gebrüder Borntraeger.

Turczaninow N. 1863. Animadversiones ad catalogum primum et secundum herbarii universitatis charkowiensis. Bulletin de la Société Impériale des Naturalistes de Moscou 36: 545-615.

Van Steenis MJ. 1950. Alphabetical list of collectors. In: Van Steenis CGGJ (ed), Flora Malesiana, Ser. I: 5-606. Jakarta, Noordhoff-Kolff N.V.

Van Steenis MJ. 1956. Citations of serials and some books. In: Van Steenis CGGJ (ed), Flora Malesiana, Ser. I, 5: cxlv-clxv. Jakarta, Noordhoff-Kolff N.V.

Van Steenis MJ. 1958. Malaysian plant collectors and collections. Supplement I. In: Van Steenis CGGJ (ed), Flora Malesiana, Ser. I, 5: ccxxxvii-cccxxxvi. Jakarta, Noordhoff-Kolff N.V.

Van Steenis MJ. 1974. Malaysian plant collectors and collections. Supplement II. In: Van Steenis CGGJ (ed), Flora Malesiana, Ser. I, 8: i-cxv. Leiden, Noordhoff International Publishing.

Ventenat EP. 1803-1808. Choix de plantes. Paris, Crapelet.

$$
\begin{aligned}
& 11=S \cdot \text { mackeeanum } \\
& 12=S \cdot \text { mariae } \\
& 13=S \cdot \text { mcphersonii } \\
& 14=\text { S. merrillii } \\
& 15=\text { S. micranthum }
\end{aligned}
$$

$$
\begin{aligned}
& 16=\text { S. papuanum } \\
& 17=\text { S. pullenii } \\
& 18=\text { S. solomonense } \\
& 19=\text { S. sundaicum } \\
& 20=\text { S. taomense } \\
& 21=\text { S. timoriense }
\end{aligned}
$$

4 - Cooper \& Jensen 1481: 21 - Cowie 10962: 21; 10990: 21 - Croft \& Lelean LAE 65393: 21 - Cruttwell 427: 5 - Cuming 1489: 6; 1775: 6; 1845 : 14 - Cumming 9029: 4; 10301: 4; 13003: 4; 13917: 4; 14140: 4; 22220: 4 - Cunningham 179: 4; 324: 21 - Curry 1507: 8.

Darnaedi 1351: 21 - De Voogd 851: 2 - Deplanche 270: 3; 441: 7 - DeVore \& Hoover 271: 6 - Djamhari 380: 21 - Docters van Leeuwen 10749: 15 - Dorgelo 1773: 2; 3054: 2.

Elbert 4173: 2; 4695: 21 - Elmer 11055: 6 - Escritor BS 21248: 6.

Fell DGF 4524: 4 - Fensham 1: 4; 275: 4; 918 : 4 - Forbes 943: 17; 3647: 21; 3758: 21 - Forster PIF 3674: 4; PIF 4119: 4; PIF 9639: 4; PIF 24230: 4 - Forster \& Liddle PIF 8615: 18; PIF 8639: 18 - Forster \& Ryan PIF 18369: 4 - Forster et al. PIF 13449: 4 - Frake PNH 38200: 6 - Franc 583: 7; 583bis: 7; 922: 20; 1496: 7; 1937: 7 - Friedberg 118: 21 - Frodin UPNG 1954: 12; UPNG 4263: 12 - Frodin \& Millar UPNG 567: 17 - Fuentes \& Fernando PPI 37363: 6 - Furuse 3331: 21.

Gaerlan \& Sagcal PPI 10166: 21 - Gibbs 6200: 21 - Godefroy 938: 3 - Godwin C 72: 4 - Gray 303: 4; 343: 4; 418: 4; 7509: 4; 20239: 4 - Green 
1803: 3 - Griffith 2/25: 18 - Guillaumin 9837: 7; 9940: 7; 10661: 7; 11052 : 7 - Guillaumin \& Baumann 9734: 20.

Hartley 10314: 5 - Heyligers 1258: 12 - Hill 1927: 4 - Hinton 268: 12 - Hoffmannsegg 90: 2 - Hokosawa 7063: 21; 7510: 21 - Hoover et al. Deden 205: 2 - Hosaka 2720: 5; 3378: 21 - Hyland 4791: 4; 5869: 4; 6107: $4 ; 11647: 4$.

Iboet 14: 19; 429: 2 - Irvine 2061: 4 - Isles \& Vinas NGF 32384: 5 - Iwanggin BW 5255: 12.

Jaag 201: 19; 349: 19; 602: 19; 739: 19; 1405: 19 - Jacobs 4703: 2 - Jago 6696: 4 - Jago \& Wannan 5104: 4; 6146: 4 - Jensen 20: 21 - Jeswiet 21: 4 - Jones \& Gray 18870: 4.

Kajewski 206: 8; 432: 8; 803: 8 - Kanehira 1708: 21; 1863: 21; 2400: 21 - Kanehira \& Hatusima 13041: 21 - Kato et al. C-3090: 15; C-3351: 15 - Kerenga et al. LAE 77525: 15 - Kitchener 64: 4 - Koorders 21455: 2; 22497: 2; 22501: 2; 23217: 2; 23489: 2; 23579: 2; 27478: 2; 28336: 2; 28599: 2; 29838: 2; 30172: 2; 36843: 2 - Kooy 341: 21; 578: 21; 681: 21; 834: 21 - Kostermans 1554: 21; 18064: 2 - Kostermans \& Wirawan 300: 2 - Kuntze 5032: 2.

Lahaie 2022: 2 - Lane Poole 421: 15 - Ledermann 10663: 12 - Lelean NGF 46372: 5 - Lowry et al. 6345: 3 ; 6347: 3.

MacGillivray 78: 4 - MacKee 1930: 12; 1976: 7; 3482: 13; 7962: 11; 12130 : 7; 14317: 3; 14356: 3; 14387: 9; 14550: 3; 14610: 7; 14932: 3; 16105: 9; 16116: 11; 16153: 3; 18329: 7; 18353: 3; 20167: 13; 21768: 7; 22995: 11; 23011: 3; 23345: 3; 25028: 3; 25049: 3; 25121: 3; 26101: 20; 26308: 11; 26381: 13; 28179: 20; 28295: 20; 29758: 7; 30034: 3; 30059: 11; 30401: 20; 30743: 13; 30754: 7; 31996: 7; 32555: 3; 36462: 3; 36515: 20; 40124: 3; 41151: 3 - Macpherson NQNC 4425: 4 - Madulid et al. PPI 11582: 14; PPI 23733: 6 - Mauriasi et al. BSIP 18205: 18 - McDonald KRM 3271: 4 - McDonald \& Batianoff 1522: 4 - McDonald \& Bean 5630: 21 - McGregor BS 32230: 6; BS 32253: 6; BS 32481: 6 - McPherson 2266: 7; 3502: 3; 4229: 13; 4561: 7; 5316: 3 - Merrill 3042: 6; 8117: 14; 8247: 14; 11617: 14 - Metzner 135: 2 - Millar NGF 14531: 5; NGF 18826: 16; NGF 18830: 5; NGF 23259: 15; NGF 23875: 16 - Millar \& Van Royen NGF 15632: 5 - Mitchell 7241: 19 - Moi 14: 5 - Moll BW 9808: 21; BW 9818: 21 - Munziger 433: 7 .

Nakisi BSIP 8017: 18 - Nielsen 569: 21.

O'Reilly 258: 4.
Pancher 225: 7 - Pedley 4809: 4 - Posthumus 3090: 19 - Powell BSIP 19870: 18 - Pullen 3245: 17; 6613: 17; 6658: 17; 6806: 17; 6855: 12 - Pulsford \& Floyd 5449: 12.

Rachmat 165: 21 - Ramo \& Nakisi BSIP 7895: 18 - Ramos BS 17403: 6; BS 42573: 14 - Ramos \& Edaño BS 26618: 6; BS 29136: 6; BS 44014: 21; BS 44046: 21; BS 44310: 21; BS 49136: 14; BS 49859: 6 - Raynal RSNH 16040: 8 - Regalado \& Sirikolo 808: 18 - Reillo PNH 16345: 14 - Reinwardt 364: 21 - Rutten 2052: 15.

Sam 182: 8 - Sands et al. 2951: 21 - Sankowsky \& Sankowsky 783: 4 - Schlechter 14263: 5; 17055: 15; 17267: 5 - Schmid 275: 8; 1038: 20 5112: 8 - Schmutz 10: 2; 1593: 2; 3216: 2; 3616: 19; 4116: 19; 4376a: 2; 6050: 2 - Schram BW 2817: 12; BW 9395: 12 - Sharpe 2806: 4 - Shearard \& Spence 85: 21 - Sidiyasa et al. TCW 3618: 15 - Soegeng Reksodihardjo 203: 4 - Soejarto \& Madulid 6336: 6 - Soejarto et al. 7914: 6 - Stevens LAE 54802: 15 - Stevens \& Lelean LAE 58536: 5 - Stone 5321: 5 - Stone et al. PPI 5471: 6 - Streimann \& Kairo NGF 26135: 15; NGF 27579: 5 - Sugau et al. 387: 21 - Sulit \& Conklin PNH 17620: 6.

Takeuchi 12564: 16 - Takeuchi \& Damas 4431: 5 - Teijsmann 7579: 21 - Thompson CHA 28: 4; CHA 89: 4 - Thorne 27574: 4 - Tippett UNPG 825: 12.

Van Borssum Waalkes 3084: 21 - Van Royen 3552: 21; 4500: 12; 5364: 21 - Van Royen \& Sleumer 6163: 17; 6934: 15 - Van Slooten 2456: 2 - Vanoverbergh 3725: 14 - Veillon 1461: 3 - Verheijen 600: 2; 940: 2; 2770: 2; 3719: 2 - Versteegh BW 3838: 21; BW 4720: 12 - Versteegh \& Vink BW 8337: 21 - Vieillard 250: 7; 706: 11; 2370: 8; 2371: 3; 2373: 3 - Vinas \& Naoni UPNG 7631: 12 - Vink \& Schram BW 12090: 21 - Virot 438: $7 ; 497: 7 ; 854: 7$.

Walsh 149: 8; 386: 21 - Wang 1446: 21 - Wannan \& Toh 2854: 21 - Webb 2064: 4 - Webb \& Tracey 10266: 4; 10723: 4; 11398: 4 - Webster 19131: 7 - Weinland 363: 17 - Whitmore BSIP 3897: 15 - Wiakabu LAE 70472: 21 -Williams 2946bis: 6 - Winckel 1397b: 2; 1910b: 2; 1919b: 2 - Wiriadinata 443: 21 - Wisse 367: 2 - Womersley NGF 5805: 17; NGF 9095: 5; NGF 19471: 12; NGF 24921: 16; NGF 24929: 16; NGF 43648: 4; NGF 43879: 16 - Wong 177: 5 - Wright NGF 11121: 5 - Wynne 20: 4.

Yates PNH 36321: 21.

Zollinger 2017: 2; 2615: 2; 8387: 2.

\section{INDEX}

The accepted names are in roman type, new names are in bold, and the synonymy and excluded names in italics. The numbers after the names refer to the numbered species in this revision.

Aspidopterys concava Turcz. excl. tomentosa (Blume) A.Juss. excl.

Banisteria tiliifolia Vent. 2

timoriensis DC. 21

Heteropterys albida Blume 2

Hiraea obscura Blume 21 ovata Blume 21

Ryssopterys A.Juss. [p. 76] sect. Stenophyllis Nied. [p. 76] sect. Tiliodes Nied. excl. abutilifolia A.Juss. 1 angustifolia Nied. 3 australiensis Nied. 4 forma elongata Nied. 4 forma stipulacea Nied. 4 austrocaledonica Nied. 7 var. primaeva Nied. 7 chrysantha Hassk. 2 cumingiana A.Juss. 6 dealbata A.Juss. 6 var. cumingiana (A.Juss.) Nied. 6 var. tomentosa Nied. 1
Ryssopterys (cont.) discolor Gand. 7 forma elongata (Nied.) Nied. 4 forma stipulacea (Nied.) Nied. 4 grandifolia Guillaumin 8 gymnopoda Guillaumin 9 intermedia Hochr. 10 microstema A.Juss. 2 ovata Turcz. excl. rufescens Turcz. excl. taomensis Baker f. 20 tiliifolia (Vent.) A.Juss. 2

timoriensis (DC.) A.Juss. 21 forma amboinensis Nied. 21 var. discolor (Gand.) M.Jacobs 7 var. neocaledonica Baker f. 7 var. tiliifolia (Vent.) K.Schum. 2 tomentosa Blume ex A.Juss. excl. Stigmaphyllon subg. Ryssopterys (A.Juss.) C.E.Anderson [p. 76] abutilifolium (A.Juss.) C.E.Anderson 1
Stigmaphyllon (cont.) albidum (Blume) C.E.Anderson 2 angustifolium (Nied.) C.E.Anderson 3 australiense (Nied.) C.E.Anderson 4 brassii C.E.Anderson 5 dealbatum (A.Juss.) C.E.Anderson 6 discolor (Gand.) C.E.Anderson 7 grandifolium (Guillaumin) C.E.Anderson 8 gymnopodum (Guillaumin) C.E.Anderson 9 intermedium (Hochr.) C.E.Anderson 10 mackeeanum C.E.Anderson 11 mariae C.E.Anderson 12 mcphersonii C.E.Anderson 13 merrillii C.E.Anderson 14 micranthum C.E.Anderson 15 papuanum C.E.Anderson 16 pullenii C.E.Anderson 17 solomonense C.E.Anderson 18 sundaicum C.E.Anderson 19 taomense (Baker f.) C.E.Anderson 20 timoriense (DC.) C.E.Anderson 21 


\section{APPENDIX}

\section{Regional keys to the species of Stigmaphyllon subgenus Ryssopterys}

\section{Australia, New Guinea, Micronesia}

1. Petiole flanked on each side by 1 bractlike triangular stipule to $1.5 \mathrm{~mm}$ long (never leafy) . . . . . . . . . . . 2

1. Petiole flanked on each side by $2-3$ leaflike stipules to 4.5 $\mathrm{cm}$ long, those next to the petiole the larger, linear to lanceolate to elliptical to ovate or obovate to orbicular, sessile or the largest with a small petiole $\ldots \ldots \ldots \ldots \ldots$

2. Petals 4-6 mm diam; sepals $1.1-1.5 \mathrm{~mm}$ long; laminas abaxially densely sericeous, the epidermis obscured or nearly so. - Indonesia (Papua), Papua New Guinea . . . . ......................... 15. S. micranthum

2. Petals $7.5-9 \mathrm{~mm}$ diam; sepals c. $2 \mathrm{~mm}$ long; laminas abaxially sparsely sericeous, the epidermis always apparent. - Papua New Guinea . . . . . . . . . . 16. S. papuanum

3. Mature laminas abaxially glabrous or glabrate with some straight appressed hairs retained near major veins and at base; anthers usually pubescent, sometimes sparsely so or occasionally glabrous. - Australia (Queensland), Indonesia (Papua), Micronesia (Chuuk), Papua New Guinea . . . . . . 21. S. timoriense

3. Mature laminas abaxially sericeous to tomentose; anthers glabrous (pubescent in S. abutilifolium of New Ireland). . 4

4. Abaxial laminar pubescence appressed, the hairs straight to wavy and roughly parallel $\ldots \ldots \ldots \ldots \ldots$

4. Abaxial laminar pubescence spreading, not appressed, the hairs crisped and curled, not aligned in parallel . . . . 6

5. Laminas abaxially densely pubescent, the hairs overlapping and the epidermis obscured or nearly so; male flowers without styles; hermaphrodite flowers with styles 2.3-2.5(-3) mm long. - Papua New Guinea, Micronesia (Chuuk) ...

5. S. brassii

5. Laminas abaxially thinly pubescent, the hairs not or barely touching and the epidermis evident; male flowers without styles or with 3 styles (free or 2 variously united); hermaphrodite flowers with styles c. $3.5 \mathrm{~mm}$ long. - Indonesia (Papua), Papua New Guinea, Australia (Queensland) 12. S. mariae

6. Anthers pubescent; male flowers with 3 styles, variously united. - New Ireland . . . . . . . . . . . . 1. S. abutilifolium

6. Anthers glabrous; male flowers with or without styles . . 7

7. Petals pale yellow or greenish cream; male flowers with styles 3.4-4.5 mm long; laminas adaxially glabrous or with a few hairs on the major veins; stipules eglandular. - Papua New Guinea .................... 17. S. pullenii

7. Petals bright yellow; male flowers without styles; laminas adaxially abundantly pubescent to sparsely so to glabrate in age; stipules with a minute glandular tip. - Australia; rare in Indonesia (Papua: Merauke) and Papua New Guinea (Central). . . . . . . . . . . . . . 4. S. australiense

\section{Indonesia except New Guinea}

1. Mature laminas abaxially abundantly pubescent, the vesture apparent to the naked eye . . . . . . . . . . . 2

1. Mature laminas abaxially glabrous or very finely and sparsely sericeous, the surface appearing glabrous to the naked eye................... 3

2. Sepals 1.1-1.5 mm long; petals 4-6 mm diam; anthers $0.5-$ $0.8 \mathrm{~mm}$ long, without apiculum; laminas abaxially densely sericeous, the epidermis often hidden, the hairs sinuous or straight. - Halmahera and Ternate, Seram, Sulawesi ...

15. S. micranthum

2. Sepals $2-2.5 \mathrm{~mm}$ long; petals $7-8 \mathrm{~mm}$ diam; anthers $1.5-$ $1.7 \mathrm{~mm}$ long including apiculum $(0.2-0.5 \mathrm{~mm}$ long) or apex merely acute; laminas abaxially tomentose, the hairs wavy to crisped to curled, in the largest laminas the hairs often straight to wavy but crisped and curled at base near costa and petiole. - Java, Flores, Sumba, Sumbawa . . . . . . . . $\ldots \ldots \ldots \ldots \ldots \ldots \ldots$ 2. S. albidum

3. Stipules leaflike, 2-3 on each side of the petiole; anthers pubescent or sometimes glabrous; embryo narrowly cylindrical, the cotyledons straight . . . . . . 21. S. timoriense

3. Stipules triangular, bractlike, 1 on each side of the petiole; anthers glabrous; embryo spheroid, the cotyledons convoluted and folded within each other. . . . . . . . . . 4

4. Laminas abaxially very finely and sparsely sericeous (glabrous to the naked eye), the hairs not or barely touching; sepals c. $1.5 \mathrm{~mm}$ long; petals $4.5-5 \mathrm{~mm}$ diam. - Sulawesi (?) . . . . . . . . . . . . 10. S. intermedium

4. Laminas abaxially glabrous or glabrate; sepals $2-2.2 \mathrm{~mm}$ long; petals 6-6.5 mm diam. - Sumba, Flores, Alor, East Timor . . . . . . . . . . . . . . . . . 19. S. sundaicum

\section{New Caledonia, Vanuatu, Solomon Islands}

(See discussion of $S$. timoriense (no. 21) for possible occurrence of that species in New Caledonia.)

1. Petiole flanked on each side by $2-3$ stipules, to $2 \mathrm{~cm}$ long and leaflike, those next to the petiole the larger, linear to lanceolate to elliptical to ovate or obovate to orbicular, sessile or the largest with a small petiole . . . . . . . . 2

1. Petiole flanked on each side by 1 triangular stipule, to 1.5 $\mathrm{mm}$ long and bractlike (never leafy) . . . . . . 3

2. Stamens 12-16; petals c. $7 \mathrm{~mm}$ long; male flowers with 3 free styles c. $5 \mathrm{~mm}$ long; dorsal wing of samara $2.9-3.1 \mathrm{~cm}$ long. - Solomon Islands ... . . . . 18. S. solomonense

2. Stamens 10 ; petals $8.5-12 \mathrm{~mm}$ long; male flowers usually without styles, sometimes the 'ovary' extended into a short beak, or rarely with $1(-3)$ rudimentary style(s) $0.05-2 \mathrm{~mm}$ long; dorsal wing of samara $3.5-4 \mathrm{~cm}$ long. - Vanuatu, New Caledonia . . . . . . . . . . . 8. S. grandifolium

3. Laminas abaxially tomentose . . . . . . . . . 4

3. Laminas abaxially sericeous or glabrous . . . . . . 5

4. Umbels with 8-18(-20) flowers; sepals $2.5-2.8 \mathrm{~mm}$ long; petals $8.5-10 \mathrm{~mm}$ diam; male flowers with 3 styles, all free or 2 united, 4.5-4.8 $\mathrm{mm}$ long; hermaphrodite flowers with styles $3.8-4 \mathrm{~mm}$ long; dorsal wing of samara $2.3-3 \mathrm{~cm}$ long. - New Caledonia (1 collection from Solomon Islands). . .

7. S. discolor

4. Umbels with 4-6 flowers; sepals $1.5-2 \mathrm{~mm}$ long; petals 6-7 mm diam; male flowers without styles; hermaphrodite flowers with styles $2.3-2.5 \mathrm{~mm}$ long; dorsal wing of samara 1.7-2 cm long. - New Caledonia.... 13. S. mcphersonii

5. Laminas abaxially sericeous, in $S$. taomense the vesture patchily deciduous in older leaves . . . . . . . . . 6

5. Laminas abaxially glabrous or with some scattered hairs 7

6. Flowers c. $15-30$ in each pseudoraceme, borne in compound inflorescences; petals 4-6 mm diam; sepals 1.1-1.5 
$\mathrm{mm}$ long; male flowers without styles; hermaphrodite flowers with styles c. $1 \mathrm{~mm}$ long, c. $0.2 \mathrm{~mm}$ diam. - Solomon Islands . . . . . . . . . . . 15. S. micranthum

6. Flowers (6-)8-15 in a solitary umbel; petals $7-9 \mathrm{~mm}$ diam; sepals $1.8-3 \mathrm{~mm}$ long; male flowers with 3 styles, free or variously united; hermaphrodite flowers with styles 3.5-4.2 $\mathrm{mm}$ long, c. $0.1 \mathrm{~mm}$ diam. - New Caledonia ......... . . . . . . . . . . . . . . . . 20. S. taomense

7. Pedicels entirely glabrous or the basal $1 / 4$ sericeous, red. - New Caledonia ... . . . . . . . . 9. 9. S. gymnopodum

7. Pedicels densely sericeous, green but the colour obscured by the vesture $\ldots \ldots \ldots \ldots \ldots \ldots \ldots \ldots$

8. Stamens 10; petals $6-7 \mathrm{~mm}$ diam; male flowers without styles; laminas $0.3-2.7 \mathrm{~cm}$ wide, linear to oblong to narrowly elliptical or narrowly lanceolate. - New Caledonia .....

3. S. angustifolium

8. Stamens 12-18; petals $9-10 \mathrm{~mm}$ diam; male flowers with styles; laminas $2.5-6 \mathrm{~cm}$ wide, narrowly lanceolate to elliptical to broadly elliptical to ovate. - New Caledonia ... 11. S. mackeeanum

\section{The Philippines, Palau, Tainan, and the Ryukyu Islands}

1. Mature laminas abaxially evenly tomentose; anthers glabrous; styles of hermaphrodite flowers 1.5-2 mm long; male flowers without styles. - Philippines .... 14. S. merrillii

1. Mature laminas abaxially glabrous or with patches of tomentum or tufts; anthers commonly pubescent or sometimes glabrous; hermaphrodite flowers with styles 3.2-4 mm long; male flowers with or without styles . . . . . . . . 2

2. Mature and younger laminas abaxially glabrous, any hairs retained at base and/or major veins straight, sessile, appressed, younger leaves abaxially sparsely sericeous and glabrescent; male flowers without styles (or rarely the rudimentary ovary extended into a beak or bearing rudimentary styles). - Philippines (Tawitawi), Palau, Taiwan, Ryukyu Islands . . . . . . . . . . . 21. S. timoriense

2. Mature laminas abaxially with patches of tomentum or tufts or glabrous, any hairs retained at base and/or major veins wavy to crisped and curled, subsessile or with a stalk to 0.1 $\mathrm{mm}$ long, younger leaves abaxially tomentose; male flowers with styles $4.2-5.3 \mathrm{~mm}$ long. - Philippines . . . . . . . . $\ldots \ldots \ldots \ldots \ldots \ldots \ldots$ 6. S. dealbatum 